Universidad Nacional de La Plata

Facultad de Trabajo Social

Maestría en Trabajo Social

Diciembre 2013

\title{
NO \\ ES \\ PURO \\ CUENTO
}

Vínculos entre docentes, niñas y niños en el acceso a la lectura literaria (20112012).

Lic. Esteban Julián Fernández

Director de Tesis: Dr. Ramiro Segura 
Comisión Evaluadora 


\section{Resumen}

Esta tesis analiza representaciones, prácticas docentes e interacciones entre estos y los estudiantes en el espacio escolar a partir de diferentes situaciones relacionadas con el acceso a la lectura literaria en el nivel educativo primario, en el marco de una reforma curricular.

Para tal fin se realizaron observaciones de situaciones de lectura, se indagó en torno a las trayectorias lectoras de las docentes y se analizaron representaciones y prácticas de niñas y niños en torno a la lectura y a la literatura en esos contextos.

Esta experiencia de trabajo etnográfico permitió problematizar las nociones de intervención predominantes en el Trabajo Social, discutiendo el estatuto de necesidades sociales.

\footnotetext{
Abstract

This thesis examines representations, teaching practices and interactions between teachers and students in the school on the basis of different situations related to access to literary reading in the primary education level, and in the context of a curricular reform.

To this end, observations of reading situations were made, background of teachers as readers were examine, and representations and practices of children as regards reading and literature in those contexts were analyzed.

This ethnographic work experience allowed to problematize the prevalent intervention notions in Social Work, and to discuss about the status of social needs.
} 


\section{AGRADECIMIENTOS}

A Ramiro Segura, porque con sus aportes y orientaciones no sólo me ayudó a concluir este trabajo: también me enseñó a disfrutar del trabajo de investigar. Gracias por el acompañamiento constante.

Al Equipo de Maestría, por su calidez y paciencia. Y por motivarnos a concluir con esta instancia de formación. A las Cátedras Derecho I y Trabajo Social IV, por las oportunidades brindadas. A toda la gente del LECyS, quienes con respeto acompañan preguntas e incertezas.

A María Laura Andreoni, porque comparte ideas solidariamente: de lo contrario esta tesis sería un plagio. $\mathrm{Y}$ porque me acompaña desde niño. A Analisa Andreoni, porque se interesa por lo que hago y porque se propuso estar en los agradecimientos a toda costa. A Camila Redondo, porque me encanta escuchar todo lo que ella sabe del vasto mundo y de los seres extravagantes que lo habitan.

A madre, porque volvió a leer. A Luisa (o Tzi-Tzi), porque siempre anda con una novela policial sobre la mesa de luz. A tía Palabra, porque a ella le debo el gusto por contar historias. A las tres, gracias por su afecto infinito y porque fueron quienes iniciaron mi acercamiento a la literatura.

A Daiana Kolman, Ana Inés Aranda y María Agustina Miguel, porque son integrantes de mi familia en La Plata, aunque las distancias demuestren lo contrario. A Natalia Rocchetti, porque nada me da tanta felicidad como escuchar de su voz el diminutivo de mi primer nombre (y porque me acompañó en el primer esbozo de este producto, cuando era todavía una naciente masa amorfa).

A Juan Manuel Introzzi, porque confía en mí y porque siempre está a la orden. A Paula Tilbe, por la calidez de sus palabras, siempre oportunas. A Néstor Aníbal Artiñano, cuando era niño.

A María Martina Iribarne, porque por sus dibujos esta tesis, simplemente, no terminó: tuvo un final feliz.

A Gabriela Knapp, porque fui afortunado en el trabajo al tenerla como compañera. Gracias por la paciencia y por enseñarme montones de cosas. A Mariel López, que suspendía el tiempo de trabajo alienador y alienante para acercar un libro, una historia.

A Poly, Elin y Dana Cordara e Hilda La Polígrafa (o cordero), porque creen en dragones, hadas y duendes (yo sigo sospechando que son unas marcianas; lo que no pongo en duda es que son adorables). A Marina D apóstrofe Alonzo, porque me presta su voz cada vez 
que necesito oír una historia y porque desde que la conozco siento que tengo un lugar en el mundo ( $\mathrm{y}$ en otros también).

A Pedro Bugani, porque aunque nunca entendió muy bien en qué consistía mi trabajo me enseñó que en la vida, además del blanco, del negro y de los grises, existen colores, ¡muchos colores! A Roxana y Valeria, bibliotecarias de la Biblioteca Popular Mariano Moreno, quienes acompañaron los años escolares: registrando mis lecturas, recomendándome títulos de libros y películas. Gracias por conversar con el Esteban Julián del pasado.

A María Julia Pandolfi, por las sesiones de té-rapia y por la musiquita que me regala. A Adriana Elena Marconi, porque somos amigos por el viento. Y porque es como el Bartolo de Devetach: siempre dispuesta a compartir desinteresadamente.

A "Yurassik", porque su sensibilidad enseña a ser valiente.

A Dante Fernández. A Joaquín Burgardt.

A todas las niñas. A todos los niños.

Por un cielo rojo ¡o del color que más les plazca!

Para que vuelen en él... 


\section{Índice de Contenidos}

Capítulo I: Surgimiento y fundamentación del problema de investigación. ..........................15

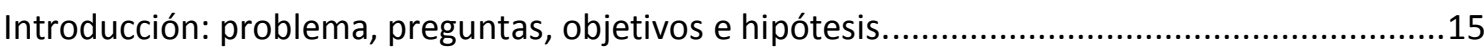

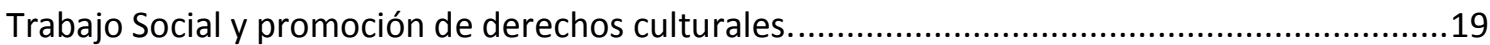

Estrategia metodológica: consideraciones sobre el trabajo etnográfico. .................................23

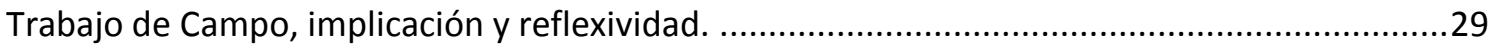

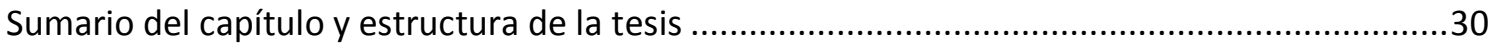

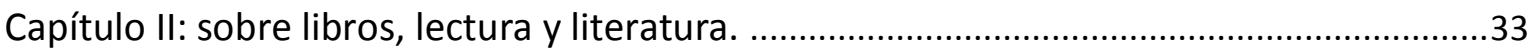

Las prácticas del lenguaje: entre la malla curricular y los entramados relacionales. ...................33

La Promoción de la lectura desde el referencial de la política pública. .....................................41

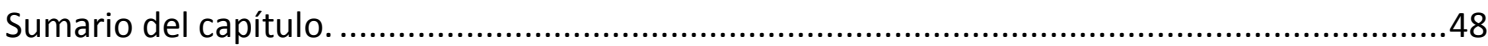

Capítulo III: Las escuelas, los cronotopos, la lectura. Descripción de los contextos de interacción.

El espacio-tiempo en las instituciones educativas: de la escuela como objeto a las lógicas escolares.

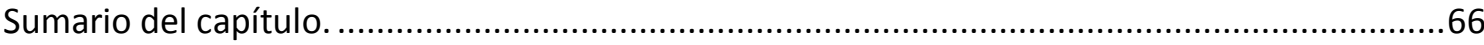

Capítulo IV. Los agentes escolares: representaciones y prácticas..........................................69

Docentes y libros: prescripciones curriculares y trayectorias lectoras...................................70

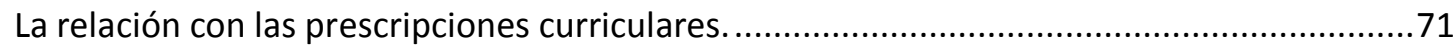

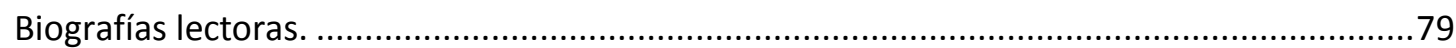

Entre los criterios de selección literaria y la construcción del sujeto lector................................87

Sobre la imagen del niño lector y los criterios de selección de lecturas. .................................98

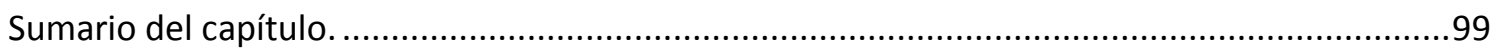

Capítulo V: La niñez y la lectura: tácticas, resistencias, fugas.............................................101

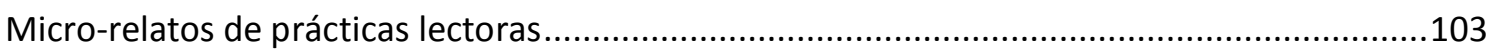

1 .

2 
3. 108

4.

La cuestión de la procedencia: nacionalidad, pobreza y racialización.

Notas sobre una construcción singular de subalternidad en espacios escolares: niña abyectaniña monstruo. 119

Sumario del capítulo. 125

Síntesis final. 129

La estatura en la infancia: el reconocimiento de niñas y niños como sujetos autorizados. 132

Bibliografía. .135 
Con mis yemas yo apagué una estrella y en la noche en vela con un beso ciego me bice algo más viejo

Me bice algo más bueno me bice algo más lejos me bice algo más bello

Manuel García, Queda lo que quema

\footnotetext{
${ }^{1}$ García, Manuel (2010). S/T (CD audio). Chile, Oveja Negra.
} 


\section{Capítulo I: Surgimiento y fundamentación del problema de investigación.}

\section{Introducción: problema, preguntas, objetivos e hipótesis.}

Esta tesis analiza las representaciones y prácticas docentes ${ }^{2}$ y las interacciones entre estos y los estudiantes en el espacio escolar a partir de diferentes situaciones relacionadas con el acceso a la lectura literaria, en el nivel educativo primario ${ }^{3}$.

La investigación que promueve la escritura de este trabajo recupera preocupaciones teórico-metodológicas, interrogantes, nudos problemáticos e incluso incertidumbres que emergieron a partir de mi inserción profesional como trabajador social en un Servicio Local de Promoción y Protección de Niños, Niñas y Adolescentes en una localidad del conurbano bonaerense y de mi rol de docente universitario como coordinador de procesos de prácticas de formación profesional en la Universidad Nacional de La Plata.

La reflexión en torno a estas experiencias profesionales y docentes me convenció acerca de la necesidad de problematizar la intervención del Trabajo Social en el desafío de complejizar la lectura de las condiciones de existencia de niños y niñas de sectores vulnerables, reconociendo que el acceso de los mismos a los bienes culturales constituye por definición un derecho a ser restituido.

En el marco de las entrevistas que los profesionales del Servicio Local de Promoción y Protección de Niños, Niñas y Adolescentes realizábamos con niños y niñas incluíamos juguetes, juegos, libros y materiales de pintura y dibujo, como modalidad de favorecer la explicitación de sus necesidades e intereses. A partir de ello, dos enunciados se fueron instalando: el primero, remite a que la inclusión de dispositivos lúdicos y expresivos posibilitaron al profesional construir un vínculo favorable con los niños y las niñas y, el segundo, que el acercamiento de las niñas y los niños a dichos dispositivos hizo explícita la ausencia de los mismos en su vida cotidiana puesto que demandaban juguetes, juegos, libros y pinturas para llevarse a su casa.

2 Con el término docentes nos remitimos a maestras de grado y bibliotecarios escolares.

3 En Argentina, la educación primaria se divide en dos ciclos: primer ciclo, que contempla los años $1^{\text {ero }}, 2^{\text {do }}$ y $3^{\text {ero }}$ y el segundo ciclo, que contempla los años $4^{\text {to }}, 5^{\text {to }}$ y $6^{\text {to }}$. 
Asimismo, de todas las escuelas primarias con las que cotidianamente trabajábamos articuladamente en pos de la pretendida restitución de derec16hos a niños y niñas que nos convocaba, una sola escuela disponía de un tiempo diario de recreación en una sala específica de juegos y lectura privada. Si bien en todas las escuelas había un espacio de biblioteca y juegoteca, el tiempo para hacer uso de dichos bienes sólo estaba habilitado durante los recreos.

Respecto a mi función docente en la coordinación de procesos de prácticas de formación profesional ${ }^{4}$ desarrollados en instituciones escolares primarias y secundarias, me interesa señalar que, con frecuencia, en las clases inaugurales de dicho espacio, algunos estudiantes suelen quejarse por haber sido ubicados en instituciones escolares, aludiendo que no era de su interés desarrollar sus prácticas allí. Cuando se les pregunta cuáles son sus intereses formativos, los estudiantes refieren que desean trabajar "con chicos o jóvenes". Suelen quedarse en silencio cuando nuestra intervención como docentes interroga: "¿Y quiénes concurren a las escuelas primarias y secundarias?".

La referencia a estos dos escenarios, el de la inserción laboral profesional y el de la práctica docente, ilustran situaciones donde la matriz escolar instituida obtura la posibilidad de responder, no a problemas propiamente escolares, sino a condiciones materiales de existencia de niñas y niños que exceden el territorio escolar. Ambas referencias son pensadas en términos de identificación de núcleos problemáticos que, en diferentes espacios, recuperan reflexivamente la antinomia entre niñez y escuela y las dificultades para construir estrategias tendientes al cuidado de niñas y niños.

El interés por indagar en torno al acceso a la lectura literaria permitió integrar en el horizonte interventivo del Trabajo Social bienes y objetos no convencionales, tales como los libros y la literatura y, a su vez, problematizar el estatuto de necesidades sociales y las condiciones necesarias para su satisfacción atendiendo, particularmente, a las trayectorias escolares de niñas y niños.

Desde estas consideraciones me permito situar algunos interrogantes que orientaron el trabajo de campo y que persistieron en la instancia de análisis de la información recabada:

1. ¿Qué supuestos ético-políticos subyacen, de modo implícito y explícito, en los procesos de alfabetización de niñas y niños en contextos escolares?

2. ¿Cuáles son las funciones, usos y sentidos que los docentes le asignan a la literatura en dichos procesos?

\footnotetext{
${ }^{4}$ Los procesos de prácticas de formación profesional que coordino se enmarcan en el cuarto año del trayecto disciplinar de la Licenciatura en Trabajo Social de la Facultad de Trabajo Social de la Universidad Nacional de La Plata.
} 
3. ¿A través de qué enunciaciones y prácticas, niñas y niños nos informan sobre su experiencia escolar en general, y sobre sus vínculos con el lenguaje poético en particular?

A partir de estos interrogantes, que trazaron el recorrido etnográfico y la instancia de análisis de la información recabada, se pudo indagar en torno a las condiciones y modalidades a través de las cuales niñas y niños se apropian, de modos diversos, de la cultura escrita y, particularmente, de la literatura. En este sentido, el objetivo general del presente trabajo se orienta a analizar las relaciones y prácticas que establecen los docentes/adultos con niñas y niños durante diferentes procesos ligados a la promoción de la lectura literaria. Desde este lineamiento fue posible identificar y analizar las formas de sociabilidad que configuran dichos procesos a partir de un trabajo de campo realizado en escuelas primarias públicas, ubicadas en el casco urbano y en zonas rurales de las localidades de Berisso y La Plata.

Los objetivos específicos que favorecieron la aproximación al objetivo mayor descomponen la problemática en unidades significativas, las cuales orientaron la búsqueda de información a partir de la identificación de fuentes y actores relevantes, configurando una mirada intencionada en los diferentes escenarios escolares transitados. Los objetivos propuestos fueron:

1. Analizar las prácticas de maestras de grado y bibliotecarias escolares ligadas a la formación de niñas y niños como lectores literarios, cursando el nivel educativo primario con énfasis en el $1^{\text {er }}$ y $4^{\text {to }}$ año ${ }^{5}$.

2. Analizar las apropiaciones que los docentes realizan en torno a los documentos normativos que estructuran la política educativa.

3. Identificar las representaciones de las maestras de grado y bibliotecarias en virtud de la población con la cual trabajan y su impacto en la efectivización de prácticas de lectura literaria.

4. Analizar los usos y sentidos de las prácticas docentes en el espacio áulico y en otras instancias que promuevan o no el acceso a los textos literarios.

5 Se tuvo en cuenta al 1er año en tanto allí inician su trayectoria escolar primaria niñas y niños. Asimismo, se consideró que, a partir del 4to año, las niñas y niños podían realizar lecturas autónomas. De todos modos, en uno de los establecimientos escolares se realizaron observaciones en todos los niveles del nivel primario. 
5. Identificar y describir el tipo de texto utilizado en las prácticas de los agentes mencionados y los criterios de selección de dicho material.

Las hipótesis interpretativas que se exponen a continuación pretenden significar algunos elementos que fijan límites y ejercen presiones (Williams; 2003) en los procesos de acercamiento de niñas y niños a la lectura literaria en espacios escolares:

1. La primera hipótesis considera que las representaciones y prácticas de los docentes constituyen uno de los elementos que condicionan, junto con las condiciones socioeconómicas, la accesibilidad a la lectura literaria de niñas y niños. Se establece aquí que ciertas representaciones de infancia, que motivan las prácticas de las maestras de grado y de las bibliotecarias escolares, limitan el vínculo entre los estudiantes, los libros y la literatura.

2. Existe en los agentes escolares un conocimiento de las transformaciones paradigmáticas que estructuran el diseño curricular pero los mismos no tienen interés en implementarlas y/o no cuentan con las herramientas teórico-metodológicas para su realización.

3. Las niñas y niños que afirman que no les gusta leer, en general, y que no les interesa la literatura, en particular, disfrutan de la lectura literaria que realizan otros en voz alta o de los relatos a los cuales acceden por vía de la narración oral. Ello evidencia que niñas y niños son lectores pese a que no hayan aprehendido las herramientas elementales para apropiarse de la cultura escrita.

A continuación se expresan los argumentos que legitiman la participación del Trabajo Social en el campo de la accesibilidad a los derechos culturales, a través de un ejercicio analítico que amplía la función socialmente asignada a la profesión. En este sentido, se ensaya una conceptualización de intervención del Trabajo Social que no se reduce a la asistencia de necesidades básicas sino que interpela el estatuto mismo de necesidades y su jerarquización. Ello permite asumir como relevante la tarea de favorecer la inclusión de los sujetos, no sólo a la cultura, sino también a los bienes artísticos, estableciendo vínculos entre la profesión y su implicancia en los escenarios escolares. 


\section{Trabajo Social y promoción de derechos culturales.}

Habermas sostiene que es "racional" la persona que no sólo interpreta sus necesidades a la luz de los estándares de valor aprendidos en su cultura, sino cuando también es capaz de adoptar una actitud reflexiva frente a los estándares de valor con que interpreta sus necesidades (Habermas, 1987: 39). Esta reflexión, si se inscribe en la dimensión teóricometodológica del Trabajo Social, ilumina y motiva la apertura y encuentro de los sujetos profesionales con necesidades, derechos y también con "problemas" novedosos.

Novedosos, no porque sean fenómenos o procesos de reciente aparición, es decir, actuales. Sino porque, aun existiendo como necesidades, e incluso como carencias, fue necesario que alcanzaran el estatuto de "problema" y de derecho. Esto significa: su reconocimiento en la agenda pública del Estado, como condición para la construcción de acciones -no siempre coherentes, no siempre articuladas, no siempre efectivas- en pos de intervenir en la distribución desigual de bienes materiales y simbólicos.

Estas reflexiones, insertas en el campo socio-profesional y socio-ocupacional del Trabajo Social, habilitaron nuevos aprendizajes en materia de promoción de derechos culturales, ya que significó romper con una perspectiva -un filtro en la mirada- que invisibilizaba el acceso a los bienes culturales como un factor decisivo en las posibilidades de constitución de subjetividades autónomas. Por el contrario, habitualmente se jerarquizan las necesidades básicas, reduciéndolas a la alimentación, habitación y educación, vinculada esta última sólo a la asistencia al establecimiento (Fernández y Marconi: 2012).

En los intentos cotidianos de los profesionales del Trabajo Social por asistir a las poblaciones vulnerables prima un imaginario que reduce las condiciones de vida de sujetos y grupos a la dimensión económica. Al respecto, interesa señalar que la exclusión no sólo refiere a una posición particular que se ocupa en la formación económico-social (Karsz; 2007) sino también a un trasfondo cultural complejo que inscribe a la infancia -a la infancia pobre- en lugares donde no es posible construirse como sujetos de derecho, en tanto no es posible representar la alimentación, la educación y mucho menos los libros y los juguetes, como derechos inalienables. En este sentido es necesario reconocer que si, tanto adultos como niños, no podemos concebir a los libros y a los juguetes como derechos de estos últimos, difícilmente sea posible instalar en la agenda pública su reconocimiento como tales. Y, tanto para los adultos como para los niños, reconocer la necesidad de libros y juguetes como un derecho, se encuentra íntimamente imbricada a variables tales como su clase social, etnia, capital social e, incluso, con la variable sexo-género, entre otras. 
Las representaciones en torno a los libros y a la literatura se relacionan con condiciones objetivas -por ejemplo, capacidad de consumo, distribución geográfica de bibliotecas- y condiciones subjetivas -en el sentido de cierta legislación interna que habilita o no al sujeto para pensarse como destinatario de textos literarios-, que configuran un abismo entre quienes pueden acceder y quiénes no. A partir de identificar como problemática el acceso de niños y niñas a los bienes culturales es que los profesionales comenzamos a reconocer la necesidad de que nuestra intervención constituyera escenarios a partir de los cuales fuera posible reconstruir su condición de sujeto capaz de vivir de acuerdo a su condición de niño (Cazzaniga: 2007).

Por ello, retomando la experiencia profesional mencionada anteriormente, es que la incorporación de textos literarios durante las entrevistas (sobre todo en su formato libroálbum), posibilitó a los niños y a las niñas problematizar el propio cotidiano, tomando distancia de aquellos discursos que los instalaban como objetos de tutela, de protección, de compasión. Habilitó a que puedan expresar su propia construcción de los problemas, ejerciendo su derecho a ser escuchado. Esto evidencia la prioridad que adquiere el diálogo entre profesionales y entre los profesionales con los sujetos que transitan las instituciones en las cuales participamos como reproductores y disruptores de lo instituido, a la vez que operamos sobre aquellos intersticios que habilitan prácticas instituyentes e inclusivas.

Trasladando estas reflexiones a los contextos escolares se puede inferir que la accesibilidad a la literatura no puede reducirse a la dimensión material sino que su análisis debe hallar también asidero en las representaciones de los sujetos y grupos pobres en torno a los libros, a la literatura, a las instituciones y mediadores que difunden y promocionan la lectura literaria, entre otras. A su vez, en tanto relación social, interesa identificar y analizar las representaciones y prácticas de maestras de grado y bibliotecarias en torno a la promoción cultural, la realización de acciones de animación a la lectura y, ante todo, indagar cómo asumen su tarea de formar lectores, resaltando en este aspecto su propia formación como lector más allá y más acá de su función docente. Estas dimensiones resultan relevantes para situar un análisis respecto de los vínculos posibles entre los sujetos y/o grupos y los textos literarios desde una perspectiva multidimensional.

Por ello, es relevante reflexionar en torno a las instituciones escolares como aliadas estratégicas en la ampliación e inscripción de niñas, niños y adolescentes en escenarios alternativos relacionados a la promoción y difusión de textos literarios y a la realización de prácticas de lectura (Fernández y Marconi; 2012a). Y ello porque, en términos cuantitativos, según el informe Atlas Mundial sobre la igualdad de género en la educación realizado por la 
UNESCO, la vida escolar en Argentina oscila entre los 13 y los 16 años -similar a lo que ocurre en Arabia Saudita, Polonia, México y Grecia-. Un dato no menor, refiere el informe, expresa que nuestro país, junto a Cuba y México, son los tres únicos países del continente con menos del 1\% de niños no escolarizados (superando a Noruega, Suecia, Finlandia y los Estados Unidos) ${ }^{6}$.

Sin embargo, dado que la escolarización de casi la totalidad de niñas y niños no significa inclusión educativa, planteada en término de igualdad de oportunidades, se hace necesaria la producción de "datos blandos", no estadísticos, a partir de la confección de un registro cualitativo sobre las interacciones cotidianas al interior del sistema escolar y de las instituciones educativas: incluyendo, en este registro, las interacciones que se dan entre los propios adultos, entre los adultos y la niñez y entre las niñas y los niños mismos (Dussel; 2004).

Cuando se construye como problemática la relación de la niñez con la accesibilidad a la literatura no se propone orientar la indagación en pos de prescribir, desde una solapada perspectiva de derechos, la importancia del lenguaje poético como herramienta para constituir subjetividad y promover reflexiones acordes a un sujeto que se asume ciudadano. Lo que interesa, siguiendo los planteos de Actis (2008: 79), es reconocer la función indelegable de las instituciones escolares y de sus agentes en la implementación de situaciones que favorezcan la apropiación de prácticas legitimadas, las cuales son básicas en la lucha contra la desigualdad de posibilidades de acceso a los bienes culturales.

Formar desde una edad temprana a los sujetos como lectores no remite a transmitir la mera capacidad de decodificar caracteres sino, en el caso de la formación de lectores literarios, al garantizar el acceso a los libros y acompañarlos en la lectura de literatura, se les ofrece la posibilidad de aprehender a disfrutar de la potencialidad del lenguaje poético como “investidura". Es decir, como posibilidad de "ocupar" o "tomar posesión”, en el sentido de ocupar un territorio imaginario (Spivak; 2008).

Cuando se habilitan experiencias orientadas a la aprehensión de herramientas y recursos que favorecen la formación de lectores literarios y el diálogo entre estos, se promueve la constitución de una conciencia que posibilita el pasaje del puro y simple poder-decir a una enunciación particular y contingente, que determina el espacio de lo propiamente mío (Virno; 2003: 79). Incluso se habilita un espacio de reserva, un escenario donde el pensamiento interpela, rechaza y reniega de los determinismos sociales de los cuales un sujeto singular es parte.

\footnotetext{
${ }^{6}$ Argentina: 99\% de escolarizados. Diario Registrado, Sociedad, 06-02-2013. Disponible en www.diarioregistrado.com
} 
La apropiación del lenguaje poético por parte de los sujetos implica su formación como lectores autónomos. Esto significa contar con un repertorio de herramientas, de un conocimiento consciente e inconsciente, en el momento de la decodificación del discurso, para acceder a la producción de sentidos (Pizarro; ibidem: 70). En este sentido, Actis (ibídem: 112), amplía la noción de lector en tanto no la reduce a la comprensión o construcción de significado en torno a un texto literario sino que inscribe la relevancia de la apropiación de competencias culturales. Desde esta consideración, no sólo se reconocen saberes y operaciones intelectuales sino que también se involucran en el análisis las tácticas que los sujetos realizan, por ejemplo, para acercarse al objeto-libro.

La mayoría de los enunciados aquí establecidos, más que realidades, constituyen proyecciones: horizontes políticos cuya concreción se considera legítima en tanto se democratizan bienes valorados socialmente pero desigualmente apropiados, en términos materiales y simbólicos. Contribuir en la constitución de encuadres más justos en pos de favorecer el vínculo entre la niñez y la lectura literaria requiere no sólo de acciones generalmente reducidas a meras actividades- sino de instancias de reflexión que procuren identificar qué instituciones y adultos elaboran prácticas que garantizan el acceso a la lectura literaria, qué posicionamientos, sentidos y representaciones se inscriben en las prácticas docentes en relación al acceso de niños y niñas la literatura, qué representaciones de niñez elaboran estos adultos, qué modalidades de prácticas de lectura literaria promueven las escuelas, qué leen estos adultos.

Desde estas consideraciones el Trabajo Social puede aportar, por un lado, a la comprensión de las lógicas ideológicas que operan condicionando la trayectoria escolar de niñas y niños, deteniéndose en una mirada de conjunto que contemple, no sólo los problemas de éstos y de sus referentes familiares, sino también problemas producidos por el mismo dispositivo escolar. Por otro lado, atentos a los aportes que el Trabajo Social puede efectuar en pos de la alfabetización de niñas y niños, es posible ampliar el horizonte asistencial incorporando los profesionales de los Equipos de Orientación Escolar en su quehacer cotidiano funciones ligadas a la promoción del libro, la lectura y la literatura.

A continuación, se expone el diseño metodológico que organizó el trabajo de campo a partir del cual se obtuvieron los insumos que posibilitaron la escritura del presente trabajo. Se ofrece una caracterización inicial de los contextos y agentes involucrados en la unidad de referencia empírica a la vez que se explicita cómo se establecieron los contactos con los referentes significativos que posibilitaron el ingreso a los diferentes establecimientos escolares. También se enuncian las herramientas diseñadas para la recolección de información y su 
posterior análisis. Dicho proceso se encuentra, a la vez, signado por una posición investigativa que también incluyó, en el devenir del trabajo de campo, intervenciones relacionadas con la narración oral y la lectura de cuentos en situaciones áulicas.

\section{Estrategia metodológica: consideraciones sobre el trabajo etnográfico.}

La elaboración de la presente tesis de maestría fue posible a partir de la realización de un trabajo de campo iniciado en el año 2011 y concluido en 2012, en el marco de la adjudicación de una beca de investigación otorgada por la Secretaría de Ciencia y Técnica de la Universidad Nacional de La Plata.

El material recolectado fue producido a partir de entrevistas semi-estructuradas y observaciones, y la construcción y aplicación de un cuestionario en contextos escolares. Además de las interacciones con agentes escolares como maestras de grado, bibliotecarias, directivos y capacitadores docentes, se trabajó con actores extra-escolares como bibliotecarias de bibliotecas populares, participantes de grupos de narración oral, entre otros actores que realizan actividades con instituciones educativas, efectivizando acciones de promoción y/o animación de la lectura literaria.

Se registraron y analizaron además las situaciones y las conversaciones sostenidas con niñas y niños que asisten a las escuelas que constituyen la unidad de referencia empírica del trabajo de investigación. También se exponen los vínculos establecidos con los adultos referentes de los mismos, a través de diálogos espontáneos generados en actos escolares, en los horarios de ingreso y egreso de la institución.

Otros materiales que constituyen la materia prima a partir de la cual fue posible aproximarse a los objetivos planteados son las fuentes documentales, específicamente el análisis de documentos escolares. Para esto, se relevaron y analizaron diversos documentos escolares vinculados con la promoción de derechos culturales y, particularmente, con la lectura. Se trabajó con los diseños curriculares del primer y segundo ciclo de Educación Primaria, circulares de la Dirección General de Cultura y Educación de la Provincia de Buenos Aires. Por último, se integraron como materiales de análisis las producciones escritas de niñas y niños que asistieron en el año 2011 a la Biblioteca Popular Pestalozzi acompañados por referentes de instituciones educativas. 
Los datos fueron producidos en dos etapas de trabajo de campo:

Una primera etapa (2011), de carácter exploratorio y general, en la que se implementó un cuestionario en 5 (cinco) escuelas de la localidad de Berisso. Se entrevistaron un total de 19 docentes: 8 maestras de primer grado, 6 maestras de cuarto grado y 5 bibliotecarias. Asimismo, fueron entrevistadas 3 directoras y 4 referentes de instituciones de La Plata y Berisso que desarrollan actividades afines al acceso a la lectura literaria en instituciones educativas, como promotores de lectura o capacitadores del distrito.

Es relevante mencionar que el contacto con algunas maestras de grado y bibliotecarias escolares fue facilitado por el encuentro con las mismas en la Biblioteca Popular Pestalozzi, en el marco de acuerdos inter-institucionales que favorecen la concurrencia de niñas y niños a una biblioteca popular de su comunidad. En la biblioteca mencionada participo como voluntario, a través de situaciones de animación de niñas y niños a la lectura literaria, los cuales se acercan con sus respectivas escuelas.

De los establecimientos educativos ${ }^{7}$ relevados en esta instancia, cuatro se inscriben territorialmente en el centro de la ciudad de Berisso y el restante en el ámbito rural. Las escuelas presentaban las siguientes características:

La escuela "A" se caracteriza por ser uno de los establecimientos educativos más demandados por las familias para que sus hijas e hijos inicien la escolaridad primaria. Cuenta con una matrícula completa, aproximadamente 30 alumnas y alumnos por grado en cada turno y las niñas y niños que concurren pertenecen a familias de clase media. Se localiza en una cuadra cercana a la zona céntrica. A partir de observaciones realizadas, tanto en situaciones de lectura efectuadas en la Biblioteca Popular Pestalozzi como en las aulas del establecimiento, se identificó que las niñas y niños del primer año se encuentran alfabetizados en los últimos meses del ciclo lectivo. Ello significa que muchos de ellos inician sus primeras lecturas y escrituras de manera autónoma, a la vez que se evidencia que cuentan con un recorrido como lectores de literatura en tanto conocen no sólo los títulos de los cuentos sino también el nombre de los autores.

\footnotetext{
${ }^{7}$ Con vistas a preservar el anonimato de las personas entrevistadas así como la identidad de los establecimientos educativos en los que se desarrolló la investigación, las escuelas se referenciarán con una letra mayúscula (escuela A, B, etcétera).
} 
La escuela “B”, la más antigua del distrito, funciona en dos turnos y la población que asiste es heterogénea en cuanto a ingresos económicos y proviene de múltiples puntos de la ciudad: barrio Solidaridad, barrio Obrero y barrio Náutico. También asisten niñas y niños de la Casa del Niño, institución dependiente del municipio. Concurren 350 alumnas y alumnos entre ambos turnos. Si bien fue una de las instituciones educativas más prestigiosas, en la actualidad posee una baja matrícula en primer grado y en una de las dos secciones que funciona en el turno tarde, en el año lectivo 2011, se sucedieron 9 suplentes en un lapso menor a dos meses. En dicha institución se pudieron realizar personalmente sólo tres entrevistas, debido a que las horas especiales ${ }^{8}$ en las cuales podían ser entrevistadas eran destinadas para suplantar a compañeras que se ausentaban por diversos motivos. Este obstáculo, que además es un dato que captura la dinámica de dicha institución, trató de superarse a través de una entrevista auto-gestionada repartida a los docentes de grado del turno tarde, pero sólo fue respondida por una docente de $4^{\text {to }}$ año.

La escuela "C" ofrece un servicio de jornada completa -8 horas- y experimenta un crecimiento de matrícula en los últimos años: en 2008 asistían 85 niñas y niños y en el año 2012 asistieron135. Asisten niñas y niños de sectores socioeconómicos vulnerables. Un $80 \%$ de la población que asiste vive en la calle Nueva York ${ }^{9}$ o en cuadras cercanas. Concurren, en número poco significativo, niñas y niños de Ensenada. Un 60\% percibe la Asignación Universal Por Hijo. Al ser una escuela de jornada completa, desde el primer ciclo se imparten las asignaturas de Informática e Inglés. Los docentes y profesionales del Equipo de Orientación Escolar refieren que la mayoría de estos niños viven con grupos familiares donde la violencia está naturalizada, a la vez que muchos de los referentes adultos no cuentan con empleo estable y en blanco.

La escuela " $D$ " también es una de las de mayor trayectoria en la comunidad berissense. Sin embargo, en la actualidad asisten un total de 66 alumnas y alumnos en ambos turnos. El primer ciclo concurre a la tarde y el segundo ciclo, a la mañana. En primer y segundo grado asisten 14 alumnas y alumnos, en tercer grado 9 y en el segundo ciclo la

\footnotetext{
8 Se refiere a las horas de Plástica, Educación Física y/o Inglés que se dictan en los establecimientos. Durante estas horas, la maestra de grado cuenta con un tiempo para planificar la clase o concretar reuniones con el Equipo Directivo. 9 La calle Nueva York es considerada escenario de la movilización obrera producida el 17 de Octubre de 1945 . En este sentido representa un enclave de gran valor histórico y simbólico asociado a lo cosmopolita, en amplia analogía con la Avenida Corrientes de la Ciudad de Buenos Aires. Este imaginario persiste, aún cuando la población que se asienta en dicho enclave es de procedencia migrante interna. En este sentido, la mirada patrimonialista insiste en recordar el pasado migrante de carácter europeo de quienes habitaron esta calle en detrimento de actualizar la mirada y conocer la constitución real de la calle Nueva York contemporánea.
} 
cantidad de niños por grado oscila entre los 11 y los 15 . Asisten niñas y niños pertenecientes a sectores socioeconómicos vulnerables, derivados de otras instituciones educativas por problemas de conducta y/o de aprendizaje, y muchos son repitentes. Asimismo, una de las problemáticas que refieren los docentes es el ausentismo. No cuentan con Equipo de Orientación Escolar propio, sino con una extensión que concurre en ambos turnos una vez a la semana, situación que hace extensiva en el tiempo la resolución de problemáticas ${ }^{10}$.

La escuela "E" cuenta con un nivel primario compuesto por 130 estudiantes y dos secciones en primer grado: una compuesta por 10 estudiantes y otra, por 8. En cuarto grado, asiste un total de 20 estudiantes. Si bien la escuela se ubica geográficamente en una zona rural, asisten a la institución niñas y niños de familias de bajos ingresos que no realizan actividades laborales de carácter rural. La inserción laboral de los hombres, mayoritariamente, se efectiviza en actividades de la construcción y, en las mujeres prima su inserción en empleos de servicio doméstico. Asimismo, algunos grupos familiares desarrollan estrategias de supervivencia ligadas a trabajos de corta duración o changas. En la actualidad se han incorporado niñas y niños cuyos padres son de nacionalidad paraguaya y peruana provenientes de los barrios Villa Argüello, Villa Zula y El Palihüe ${ }^{11}$.

Una segunda etapa de investigación (2012) se desarrolló en la escuela "F" de la localidad de La Plata. El trabajo de campo se efectivizó a partir de una inclusión plena en la institución escolar. Las actividades realizadas en dicho escenario fueron diversas: observaciones participantes en diferentes espacios (biblioteca, recreos, actos escolares, situaciones áulicas, como por ejemplo, hora de lectura), entrevistas y conversaciones espontáneas con los diversos actores involucrados con el establecimiento (comunidad educativa, referentes familiares, niñas y niños). Como parte del acercamiento a las niñas y niños, acordé con los integrantes del equipo directivo la realización de situaciones de lectura durante los recreos (en el Salón de Usos Múltiples). Estas situaciones permitieron dialogar ampliamente junto a niñas y niños en relación a su propio cotidiano y a su trayectoria escolar.

\footnotetext{
${ }^{10} \mathrm{El}$ establecimiento presentaba un deterioro edilicio que desmotivó a las familias a enviar a sus hijas e hijos y su refacción concluiría a principios del año 2012. La restauración de dicha institución, patrimonio histórico de la ciudad, fue financiada con fondos de Nación y de Provincia. Recibieron financiamiento del Programa de Inclusión Educativa para la compra de materiales y textos literarios. Dicho Programa, además, realiza un monitoreo respecto de la implementación del diseño curricular en dicha institución, de la calidad del servicio ofrecido y de los aprendizajes adquiridos por las y los estudiantes.

${ }^{11}$ Las tres localidades mencionadas se caracterizan por estar constituidas por sectores socialmente vulnerables.
} 
En lo relativo a las características de la escuela, según el Informe Diagnóstico elaborado el año 2011 por la institución ${ }^{12}$, un $95 \%$ de la población que asiste proviene del barrio Islas Malvinas o Las Malvinas, cuyo clivaje geográfico se extiende desde la calle 149 hasta la calle 151 y desde la calle 32 a la calle 36. También concurren niñas y niños provenientes de La Granja ${ }^{13}$, que se extiende desde la calle 31 hasta la calle 520 y desde la calle 131 hasta la calle 145 y de un sector geográfico comprendido desde la calle 532 a la calle 525, entre calles 15 y 25. Sólo un $5 \%$ vive en un radio menor a 10 cuadras. Por ello es que se explicita en el Informe Diagnóstico que la población que asiste a dicha institución no es la esperada, si se tiene en cuenta el anclaje geográfico de la institución en el casco urbano de la ciudad de La Plata, habitado predominantemente por sectores medios. La comunidad que asiste a dicha institución es caracterizada desde su pertenencia a un "área social de alto riesgo", según detalla el informe mencionado.

En pos de caracterizar a las maestras de grado y bibliotecarias escolares entrevistadas, vale mencionar que provienen, en su mayoría, de las comunidades en donde se desempeñan como docentes. Sólo dos maestras de grado, en condición de suplentes, provenían de otras provincias (Jujuy y Salta). De manera contingente, la mitad de las docentes entrevistadas se formaron en Institutos Superiores de Formación Profesional públicos y la otra mitad en instituciones privadas de carácter religioso. Cuentan todas con una experiencia laboral como docentes superior a los 5 (cinco) años, excepto una de las entrevistadas que posee una trayectoria laboral más breve. En su mayoría, poseen una experiencia docente que promedia los 10 (años) y sólo se registra una trayectoria laboral superior a los 20 (veinte) años.

En cuanto al clivaje género, la mayoría de las entrevistadas son mujeres, con excepción de un docente varón. Vale aclarar que en el transcurso de la investigación sólo se hallaron dos varones ejerciendo la docencia como maestros de grado en las instituciones de referencia ${ }^{14}$. Puede contabilizarse como docente varón un capacitador en Prácticas del Lenguaje entrevistado, pero que no ejerce funciones en ninguna de las escuelas mencionadas.

12 Dicho documento institucional fue elaborado por los directivos y los profesionales integrantes del Equipo de Orientación Social.

${ }^{13}$ Tanto el barrio Islas Malvinas como La Granja, constituyen zonas alejadas del casco urbano de la ciudad de La Plata. Son enclaves geográficos habitados, en un gran porcentaje, por población migrante interna y de países limítrofes. La infraestructura de servicios básicos es deficitaria y la población adulta se desempeña en trabajos informales. La Granja está conformada, particularmente, por la comunidad toba y, junto con el barrio Islas Malvinas, son espacios donde se lucha cotidianamente por la regularización de la propiedad de las tierras donde se asientan las viviendas.

${ }^{14}$ De aquí se justifica que, a lo largo del trabajo, utilice el femenino para referirme a docentes dado que el número de varones que integran la unidad de referencia empírica es numéricamente inferior. 
Son escasas las docentes que realizaron capacitaciones vinculadas a la asignatura Prácticas del Lenguaje u otros cursos transversales, por ejemplo, relacionados con la lectura literaria, aunque otros espacios pertenecientes al sistema educativo formal (por ejemplo, el Centro de Información Educativa) ofrece alternativas variadas en lo que respecta a alfabetización, formación de lectores, entre otras temáticas afines.

Todas las escuelas analizadas en esta investigación cuentan con un espacio de biblioteca, pero en uno de los establecimientos las dimensiones no permiten disponer de una sala de lectura. Sólo en dos establecimientos se cuenta con personal de atención bibliotecológica en ambos turnos. En el resto de las instituciones, quien se encarga del espacio de biblioteca alterna los turnos. El personal con "tareas pasivas" suele ser ubicado en la biblioteca escolar.

En todas las escuelas se les solicita a las bibliotecarias que acompañen el aprendizaje de niñas y niños, contribuyendo al trabajo de sus colegas, a través de su inclusión en el aula u organizando actividades que promuevan las visitas de los diferentes grupos a la sala de lectura. Todas las escuelas cuentan con un Proyecto Institucional de Lectura que pretende establecer los objetivos de las prácticas de lectura y situar qué tipo de textos y qué obras se leerán en el transcurso del año.

Como se desarrollará en detalle en la tesis, muchas docentes entrevistadas refieren que leer es importante pero que no tienen tiempo para ello en su vida cotidiana. Fueron escasas las docentes que refirieron dedicarle un tiempo a la lectura personal, particularmente literaria. Asimismo, reclaman que sus estudiantes no leen y se registró que, con frecuencia, se identifican a las nuevas tecnologías (teléfonos móviles, Internet, consolas de video) como causantes del distanciamiento de niñas y niños de la lectura.

Por último, es menester señalar que todas las escuelas destinan una hora de lectura literaria por semana, generalmente los viernes, donde se desarrollan diferentes situaciones para que niñas y niños lean por su cuenta aquello que les interese leer o para realizar la lectura de alguna novela de manera colectiva. Esta hora de lectura pretende "ser más libre", en el sentido de propiciar el gusto por la lectura sin que se perciba como una obligación.

A partir de la propuesta metodológica diseñada, se buscó una comprensión de la dinámica educativa y, específicamente, de las prácticas de lectura, desde los discursos y prácticas docentes que particularizan las dinámicas institucionales. Desde el material 
producido a partir de las desgrabaciones y transcripciones de las entrevistas realizadas y la elaboración de notas de campo, las cuales fueron posteriormente re-escritas en pos de condensar dinámicas institucionales, se prosiguió con el análisis del discurso de los actores. Ello significó poner en tensión las representaciones y prácticas de los sujetos con las categorías estructurantes del marco teórico, a la vez que fue necesario implicar otras herramientas conceptuales. A partir de esto fue posible situar las dimensiones generales que constituyen y orientan la caracterización de la accesibilidad a la lectura literaria.

\section{Trabajo de Campo, implicación y reflexividad.}

En lo que respecta a las condiciones de inserción como investigador, conviene establecer algunas puntualizaciones. Durante el período previo al trabajo de campo realizado en el año 2011, participé como narrador en diferentes visitas que las escuelas primarias de Berisso realizaban a la Biblioteca Popular Pestalozzi. A partir de esta inserción fui conociendo a las docentes, lo cual facilitó su aceptación de ser entrevistadas.

Estas intervenciones en la biblioteca favorecieron que niñas y niños me reconocieran cuando asistía a las escuelas. También me saludaban por la calle, recordando mi nombre o mi pertenencia institucional como voluntario de la Biblioteca Popular Pestalozzi. Si bien en calidad de investigador no pude participar en todas las escuelas como observador en situaciones áulicas y/o conversar con las niñas y los niños, aproveché estratégicamente mi condición de voluntario para acceder a información sobre la dinámica áulica. Es así que, en algunas oportunidades, concurrí como voluntario a dichos establecimientos con la intención de llevar libros y contar historias y, a la vez, registrar las relaciones entre docentes y estudiantes en su propio espacio, en el marco de actividades consensuadas entre la Biblioteca Popular, docentes y directivos.

Durante el periodo 2012 armé en la escuela donde realicé el trabajo de campo un espacio de lectura al cual concurrían niñas y niños, sin obligación, durante los recreos. Lo significativo fue que las niñas y niños comenzaron a invitarme a leer en su aula o a que les contara alguna historia. Para ese entonces, reparé en que no sólo estaba investigando sino que, de algún modo, me estaba convirtiendo en cierto referente literario para esos niños. Haber realizado algunos cursos de narración oral, de selección literaria y, a la vez, recuperar la experiencia de leer literariamente, contribuyó a apropiarme de algunos recursos y herramientas que, a través de la palabra, me permitían tejer puentes entre la niñez y el lenguaje poético. 
Otra cuestión significativa: a partir del reconocimientos de niñas y niños, algunas docentes me solicitaron que interviniera en la resolución de conflictos, ya sea para "calmarlos" o bien para saber "qué le anda pasando". Incluso, maestras e integrantes del equipo directivo solicitaban que las asesorara sobre cómo resolver determinadas problemáticas. Los estudiantes, sobre todo las niñas, también se acercaban a plantearme problemas relacionados con su escolarización o con su vida por fuera de la frontera trazada por el espacio escolar.

En esta escuela me encontré en algunas oportunidades “dando clase”. En una ocasión, una docente quería empezar a trabajar mitos y me solicitó si podía hacer alguna introducción, generar ciertas condiciones para involucrarlos progresivamente en el relato de los personajes del Olimpo. Fue así que armé una clase expositiva, incluyendo dibujos en el pizarrón, para explicar el origen del Universo y el surgimiento de los personajes emblemáticos de la mitología griega. En otra oportunidad, otra docente del primer año me manifestó "estar perdida" con la parte de lectura literaria: qué leerles, qué hacer después de cada lectura. Fue así que nos juntamos dos veces para pensar objetivos, materiales de lectura y algunas actividades. Para mediados de año fue la única docente que armó una biblioteca áulica y generó un ambiente para la lectura, adornando una esquina del salón y reciclando una estantería de cartón corrugado como biblioteca. También se disfrazaba con bonete de bruja y se paseaba con una escoba, antes de iniciar la lectura de una historia que, por supuesto, involucraba pociones y gatos negros. Me agradeció el haberla apoyado en su tarea como docente; yo agradezco que me haya permitido conocerla, no sólo como docente, sino también como, madre, esposa, hija y mujer.

De esta manera, en el propio devenir de la investigación fui tejiendo lazos con docentes, directivos, niños y niñas, negociando mi lugar en el campo, a la vez condición de posibilidad y producto de las interacciones sociales que todo proceso de investigación social involucra y, en cierto sentido, exige. Por esto, la reflexividad sobre mi lugar como actor que forma parte del campo (y de las prácticas y los sentidos) que busca comprender acompañó todo el proceso de investigación.

\section{Sumario del capítulo y estructura de la tesis}

En este capítulo se apeló a la experiencia como profesional y como docente situando las coordenadas que permiten poner en cuestión la accesibilidad de niñas y niños a los bienes 
culturales y, particularmente, a la lectura literaria desde una doble dimensión: material y simbólica. A su vez, se postuló una conceptualización inicial de alfabetización y de lector asida, no a una perspectiva técnica e instrumental, sino en plena consonancia con la decodificación de mundo (Eco; 1987): ello supone atender a las formas a través de las cuales niñas y niños son inscriptos en condiciones de vulneración, no sólo por su posición en la estructura social, sino por la práctica misma de funcionarios públicos, tales como docentes, trabajadores sociales, entre otros agentes.

Asimismo, se reflexionó en torno a los modos tradicionales de intervenir del Trabajo Social para luego situar la importancia de ampliar sus funciones, atendiendo a un "nuevo mapa de desigualdades" que permite considerar como un derecho a ser reconocido el usufructo de los bienes artísticos y culturales por parte de los sectores socialmente desfavorecidos. Esta cuestión posibilita re-pensar el lugar de la profesión en el marco del trabajo en contextos escolares desde una perspectiva integral que apueste a la socialización de niñas y niños desde una perspectiva de derechos.

Por último, se establecieron los objetivos, hipótesis y preguntas que direccionaron la realización del trabajo de campo, a la vez que se explicitaron los actores y fuentes que integran la unidad de referencia empírica, las herramientas diseñadas para la recolección de información y una breve caracterización de las docentes y de los contextos institucionales en los cuales desarrollan su quehacer profesional.

Los resultados del trabajo de campo se organizan en cuatro grandes capítulos.

En el capítulo titulado "Sobre libros, lectura y literatura" se presenta, por un lado, el lugar que los libros, la lectura y la literatura han tenido al interior del dispositivo escolar, en tanto escenario de acceso de amplios sectores poblacionales a la educación y a la cultura. Por otro lado, se recupera la procesualidad histórica que configuró la política de promoción de la lectura, su relación con el retorno a la democracia y los alcances y limitaciones de dicha herramienta para constituir lectores.

En el capítulo titulado "Descripciones de los contextos de interacción”, a través de la exposición de notas condensadas y la descripción densa, se presentan las instituciones escolares en las cuales realicé el trabajo de campo. Dichos escenarios son significados a partir de los espacios y tiempos dedicados a la lectura y a la literatura y a las formas de relacionarse las docentes entre sí y con las niñas y niños a su cargo.

En el capítulo siguiente, titulado "Los agentes escolares: representaciones y prácticas", se instala un análisis del quehacer de maestras de grado y bibliotecarias escolares atendiendo, por un lado a la relación que establecen con los libros mediatizadas por las directrices del 
diseño curricular y por su propia biografía lectora. Por otro lado, a partir del vínculo docente con las niñas y niños, se identifican y analizan las representaciones de infancia y las ideas que estos adultos portan respecto de los sujetos a su cargo.

En el último capítulo, titulado "La niñez: tácticas, resistencias y fugas", se exponen las prácticas de niñas y niños para situar no sólo cómo se apropian de los libros, la lectura y la literatura, sino también para explicar cómo construyen una mirada original del mundo y sus relaciones. 


\section{Capítulo II: sobre libros, lectura y literatura.}

Los libros, la lectura, la literatura. Escenas de lectura, hábitos de lectura, pérdida de interés en la lectura. Políticas de fomento lector, acciones de animación a la lectura, obstáculos en el acceso a los libros. Leer en familia y en la escuela, leer sólo en la escuela. Leer como imperativo, leer desde el deseo, ser un lector autónomo.

La cultura que ordena, el arte que juega interpelando ese orden y ambos, cultura y arte, dimensiones configuradoras de nuestra experiencia subjetiva, elementos constituyentes de nuestra posición de sujeto, tamizados por una posición de clase que condiciona, aunque no determina, nuestra experiencia de mundo.

En el presente capítulo se exponen dos ejes fundamentales para conocer el lugar material y simbólico que los libros, la lectura y la literatura han tenido en nuestro país. Es así que, en un primer momento, se establece un breve señalamiento histórico que permite identificar el lugar de la escritura y la literatura en las instituciones escolares, a la vez que se evidencian algunas transformaciones operadas a nivel institucional, como así también de los usos y sentidos de la literatura en dicho dispositivo. Por otro lado, en un segundo momento, se puntualiza la procesualidad histórica que configura la política de promoción de la lectura, que exceden el ámbito escolar, pero que tienen a la escuela como uno de los dispositivos relevantes para su implementación.

\section{Las prácticas del lenguaje: entre la malla curricular y los entramados relacionales.}

Las escuelas donde se realizó la investigación pertenecen a la jurisdicción educativa de la provincia de Buenos Aires donde, en concordancia con la derogación de la Ley Federal de Educación en el año 2006 por la Ley 26.206, se incorporó recientemente la asignatura Prácticas del Lenguaje, transformando la tradicional enseñanza de la lengua y la literatura. Esta modificación curricular considera el texto literario no sólo como dispositivo para la alfabetización de alumnas y alumnos, sino también como herramienta para la construcción de una subjetividad lectora en sentido pleno. A su vez, se hace explícita la responsabilidad 
docente de definir ámbitos que vinculen a la niñez con la lectura literaria atendiendo sus implicancias culturales, ideológicas y filosóficas.

Tal como se expresa en los diseños curriculares de los diferentes niveles educativos, como así también en otros documentos afines emanados de la Dirección General de Cultura y Educación de la Provincia de Buenos Aires, la asignatura mencionada contempla de manera privilegiada las prácticas de lectura, escritura y oralidad que se ponen en juego en el ámbito de la literatura, avanzando a partir de ello en las situaciones de reflexión sobre los hechos del lenguaje y planteando una concepción de la evaluación que intenta ser coherente con el enfoque de enseñanza adoptado ${ }^{15}$

Interesa señalar que a partir de la vigencia de la Ley de Educación Provincial $\mathrm{N}^{\circ}$ 13.688, se elaboran diseños curriculares que se asumen como comunes, prescriptivos, paradigmáticos y relacionales, los cuales pretenden abordar la tensión entre la igualdad de acceso al patrimonio cultural de la humanidad y el respeto a la heterogeneidad de sujetos y grupos sociales y culturales, sin que ello niegue el principio de igualdad de oportunidades (DGCyE; 2007). A su vez, la conceptualización referida en torno a la alfabetización se materializa en el plexo normativo correspondiente a la Ley de Educación Nacional, la cual establece el objetivo de fortalecer la centralidad de la lectura y la escritura, como condiciones básicas para la educación a lo largo de toda la vida, la construcción de una ciudadanía responsable y la libre circulación del conocimiento (LEN; 2006).

Puede decirse que, desde un diseño curricular prescriptivo emergen, indefectiblemente, prácticas de adecuación de objetos comunes apropiados diferencialmente por los sujetos, en este caso: docentes. También podría explicitarse que ciertas modificaciones curriculares intervienen en pos de instalar objetos indiferentes a los sujetos y/o actores educativos, como así también apostar a la construcción de otras formas de relación entre esos objetos y los agentes mismos. Lo cierto es que toda prescripción no guarda sino la ilusoria realización de un conjunto de principios rectores, con independencia de las instancias que mediatizan su concretización. Es decir, surgen formas conflictivas a partir de las cuales lo normativo se pone en tensión con las múltiples determinaciones que objetivan el cotidiano educativo de niñas y niños.

A partir de ello, imposible es plantear la lectura literaria como un objeto a ser problematizado al interior de un documento, tal como lo es el diseño curricular, con la intención de agotar allí la complejidad de las potencialidades y limitaciones del mismo para la constitución de una subjetividad lectora en sentido pleno. De hecho, pensar en términos de

\footnotetext{
${ }^{15}$ Publicación electrónica en http://abc.gov.ar
} 
currículum establece el imperativo de articular una lectura que problematice las coordenadas discursivas y su implicación en las prácticas de los sujetos y actores, en el complejo entramado que establece las condiciones de existencia de instituciones particulares, en correlato con sus lógicas, sus ritos, sus intereses.

Es desde esta consideración que, en pos de reflexionar sobre la accesibilidad de niñas y niños a la lectura literaria, necesariamente el objeto de estudio convendrá en centralizarse en las prácticas mismas. El desplazamiento del objeto a las objetivaciones, permite situarnos en el análisis en torno a cómo las relaciones con los objetos son las que los constituyen, de una manera específica cada vez y según ensamblajes y distribuciones siempre singulares (Chartier; 1992: 42).

Históricamente, la inclusión de la lectura como un tema de interés público se relaciona íntimamente con el desarrollo de los sistemas educativos (Peña y Cortés; 2004). Sin embargo, dicha vinculación incorporó, de manera reciente, el conocimiento producido por la sociología de la lectura y el desarrollo del pensamiento en torno a la infancia (Lluch; 2003).

Gustavo Bombini (2008) señala que sobre la vieja agenda de la escuela pública del siglo XIX que prioriza el ingreso de los ciudadanos a la cultura escrita, se vuelve necesario discutir aspectos más generales que nos permitan realizar una reconsideración sobre los sentidos de la implementación de políticas de promoción de la lectura. Ello supone sostener en el nivel de la problematicidad, tensiones históricas, de extensa perdurabilidad temporal ya que como indica Soriano $(1993 ; 49)$ la escuela, a pesar de su éxito pasado y sus esfuerzos presentes, no ha sabido resolver los problemas planteados por la entrada masiva en el ciclo de escolarización de los niños del pueblo, tan inteligentes como los otros, pero carentes por lo general de ciertos hábitos inherentes al medio. Es así que la literatura inscripta en las instituciones escolares requiere situar las acciones de los agentes educativos que definen las funciones de ese lenguaje en una comunidad dada y que estructuran, en gran medida, lo que dicha comunidad percibe como literatura; no sólo con la intencionalidad de identificarla sino como forma de experimentarla, buscarla e, incluso, acercarla a otros sujetos.

Si la socialización de la niñez en relación a los derechos culturales es planteada desde una perspectiva lúdica y afectiva y reconocida como una premisa que debe organizar las intervenciones docentes, ello es porque el impacto de las instituciones escolares en las trayectorias lectoras de los sujetos es determinante. A partir de ello, interesa señalar que las prácticas culturales posteriores de las niñas y los niños se relacionan más con el capital escolar adquirido que con otros factores sociales, como el origen social de los lectores (Colomer; 2009: 47) 
Sin embargo, cuando se reflexiona en torno al vínculo entre las inevitables obligaciones que asume socialmente la escuela con respecto a la formación de lectores y la posibilidad de crear condiciones para que tales lectores puedan elegir qué leer y cómo leer en su ámbito (Siro; 2010), las relaciones entre los actores implicados exigen una posición que no puede reducirse al mero uso didáctico y moralizante de la literatura ${ }^{16}$. Y ello porque, siguiendo los planteos de Siro (ibídem), la escuela tiene la responsabilidad de garantizar el contacto sistemático con la cultura escrita, y los docentes la responsabilidad de crear las mejores condiciones para que todos o la mayoría de los alumnos se constituyan como lectores autónomos.

Para proseguir organizadamente en este desarrollo, conviene situar una afirmación: la posibilidad de las instituciones escolares de constituir sujetos - niñas y niños- como lectores autónomos, al decir de Bourdieu (2010: 105), implica problematizar la relación con los posibles, puesto que ello es una relación con los poderes. En este sentido, las condiciones materiales de base, las que se corresponden con la inscripción en un grupo familiar pobre, se imbrican a otros escenarios institucionales que afirman o rechazan dichas condiciones: como naturales o como injustas, entre otras formas posibles de etiquetar las formas de poder que caracterizan la sociabilidad al interior de un grupo determinado y en su relación con otros grupos y/o instituciones.

De esta manera, el gusto por la lectura literaria no sólo se revela y explica por el capital económico de los sujetos, sino por un cúmulo de discursos y representaciones cuya internalización, de manera contingente, amplía o cercena las posiciones posibles a partir de las cuales los sujetos se representan a la misma. Asimismo, siguiendo a Bernard Lahire (citado por Roffo; 2006), en el mundo escolar se encuentran las primeras grandes desigualdades, en tanto los niños de los ambientes más desprovistos de recursos culturales y escolares, con padres que no tienen títulos y que pueden ser en algunos casos analfabetos, suelen tener experiencias dolorosas en la escuela. Porque lo que descubren en ese universo rara vez confirma lo que ellos han adquirido hasta ese momento en su familia.

A partir de ello, un eje de análisis para problematizar el vínculo entre escuela y literatura necesariamente requiere incorporar, como estrategia metodológica, las trayectorias socio-familiares de las niñas y niños y la diversidad lingüística. Esta cuestión ha sido cara a las instituciones educativas, e irresuelta en términos de conflictividad: conflictividad entre una lengua estándar y la lengua que portan los sujetos y que da cuenta de su identidad, el mandato

\footnotetext{
${ }^{16}$ En su vertiente tradicional, aunque no excluye prácticas escolares contemporáneas, la literatura no sólo debía abordar temas "aptos" para niñas y niños sino, además, contribuir a moldear su comportamiento en pos de la constitución de "buenos ciudadanos".
} 
homogeneizador frente a una población culturalmente diversa, el imperativo de coagular esa diversidad lingüística y cultural en una lengua escolar hegemónica (Sardi; 2007). En detrimento de la monoglosia como política lingüística (Sardi; ibídem), se trata de construir un posicionamiento como agente escolar orientado, no a deslegitimar las prácticas lingüísticas de niñas y niños, sino a reconocer en esas prácticas la lucha que los mismos traban cotidianamente para la supervivencia, para tener un lugar, para hacerse oír y participar (Sawaya; 2008).

La forma en que los sujetos pobres ingresan al sistema escolar está históricamente determinada, y por ello las oportunidades de transformación de los patrones de integración a la instituciones educativas es contingente. Ello admite la representación de otros modos de imaginar la trayectoria educativa de niñas y niños, atentos a los usos sociales del lenguaje y no a formas pre-establecidas, reconocidas como legítimas y correctas. Al respecto, Bombini (ibidem), apunta a sostener una hipótesis donde la resistencia de sujetos y comunidades a la apropiación de estándares impuestos no sea leída en clave deficitaria sino como parte de una realidad compleja.

Otra cuestión a desandar, en término de entramados relacionales de poder, es el uso escolar que se efectiviza en torno a la literatura, condición esencial si uno de los objetivos de la práctica educativa es formar lectores autónomos. Y ello porque, desde su ingreso a las aulas, la literatura quedó asida a la didáctica desde un doble aspecto (Escarpit; 1993: 38): como literatura pedagógica netamente utilitaria (libro escolar) y como literatura moral (fábulas, cuentos, etcétera) o religiosa (vida de santos).

Autores de la talla de Roland Barthes, sostiene Bombini (2007), expresan que la literatura no es enseñable, por lo cual este último defiende a la literatura del atenazamiento curricular, aludiendo que la controversia es también de orden didáctico, pues lo que se juega es un modo de gestionar la clase y de poner a circular ciertos bienes culturales.

Conviene aquí instalar la conceptualización de transposición didáctica de Chavelard (citado por Culebro Trujillo; 2007), con la cual se refiere al trabajo que convierte un objeto de saber que ha de enseñarse en objeto de enseñanza. Ello nos conecta con dos cuestiones fundamentales para pensar la educación literaria: la primera, remite a considerar la incompatibilidad entre la estructura del sistema educativo y su función de formar lectores literarios, en tanto la naturaleza de la institución escolar se caracteriza por la obligatoriedad de concurrir, el control sobre lo que enseña y lo que se aprende, la evaluación de lo aprendido por los alumnos, y que ello cercena los derechos del lector (Siro; ibídem). La segunda, nos introduce en la relación entre docentes y lecturas, pero no desde las teorizaciones que existen 
al respecto, sino desde los aportes del propio sujeto -el maestro-, narrando su historia de lectura, su relación personal con ese objeto cultural que lleva inscripto como adulto alfabetizado y como prescripción profesional (Leiza de Almada y Duarte; 2005).

Si se asume como relevante el papel de las instituciones escolares, aunque más potencial que real, en el proceso de construcción de historias lectoras, es decir, en el caudal de textos que han leído o escuchado los estudiantes y que va construyendo su relación con los libros, con la literatura, los textos de estudio u otro tipo de textos (DGCyE; 2007), la práctica docente necesariamente se realizará -no sin complejidades y complicaciones-, sobre la idea de que el acceso a la lectura no se da de manera homogénea, sino de acuerdo con el lugar que se ocupe en el espacio social, de acuerdo con la generación y con los diferentes modos de socialización (Saintout; 2007).

Estas perspectivas trastocan las pautas alfabetizadoras históricamente reproducidas por el común denominador de las instituciones escolares ya que, siguiendo a Rockwell (2001), en el contexto escolar, la manera de leer se centra más en la corrección y reproducción literal del texto, y no en la construcción de sentido.

La inscripción del principio de disfrute estético en torno a la literatura, anclado en las instituciones escolares, deviene problemático para sus agentes en tanto construir dicha posibilidad, a partir de la familiarización con los libros, supone multiplicar y diversificar las situaciones de interacción entre libros y lectores (Amado, citada por Actis; ibídem: 79). Sin embargo, el escaso bagaje de libros infantiles leídos por los docentes impide seleccionar y mediar individualmente con eficacia (Cañón; 2002), evidencia de las consecuencias que lo cuantitativo impone a la calidad en el acceso a la literatura.

Asistimos a un paradigma que, en términos de alfabetización en contextos escolares, al decir de Jaimes Carvajal (2005), no se reduce a enseñar a leer y escribir sino que trata de posibilitar que los niños reconozcan la tecnología de la escritura insertándola en su existencia como producción humana compartida y cuya estructura y funcionamiento sirven para la construcción de la significación que puede ser interpretada a través del diálogo.

A los efectos de analizar la institucionalización de la política de promoción de la lectura en escuelas públicas interesa reconocer que la centralidad de las mismas para dicha empresa supone problematizar sus objetivos y funciones. Y ello, porque la materialización de una política de promoción de la lectura articulada con el sistema escolar requiere asumir el desafío de cambiar las vinculaciones cotidianas con la cultura escrita. Esto significa, siguiendo a Rodríguez (1995), que sin resignar las metas de alfabetización masiva y de escolarización 
universal de la población en edad escolar, las escuelas asuman y promuevan la necesidad social de leer, supuesto no analizado de las políticas de promoción de la lectura.

Sin embargo, la necesidad social de leer no es criterio suficiente para que se desarrollen coherentemente un conjunto de acciones tendientes a promover la vinculación de niñas y niños con la lectura, particularmente literaria. Es así que dicha necesidad debe ser concebida, además, como derecho, lo que supone su inscripción en la agenda pública de Estado, su concretización en planes, programas y proyectos. Asimismo, al conjunto de políticas y normativas relacionadas a la temática en cuestión habría que añadir un análisis que identifique y reconozca aquellos procesos educativos que no pueden ser manipulados y controlados inmediatamente por la estructura educativa formal salvaguardada y sancionada por la ley (Mészáros; 2008: 49).

Desde esta perspectiva, deviene inevitable involucrar la formación y ejercicio docente como uno de los elementos que posibilitan una lectura, en clave de complejidad, de la mediación de la política en materia de promoción de la lectura en instituciones escolares. $\mathrm{Al}$ respecto, numerosos análisis señalan que uno de los motivos de que la participación en la experiencia escolar no implique para la mayoría de los sujetos una inscripción definitiva en las prácticas sociales de lectura y escritura y un interés por leer y escribir es la insuficiente e inapropiada formación del profesorado (Osoro; 2002). Siguiendo a Mscitti (2009: 174), una de las falencias en la formación docente remite a que dicha experiencia omite un análisis de las prácticas de lectura literaria atento a una doble mirada: por un lado, al texto y, por otro lado, a la construcción de la postura pedagógica. Esto se evidencia en aquellos discursos docentes que sostienen, desde esquemas teórico-prácticos tradicionales, usos y sentidos escolarizantes en torno a los textos literarios.

La idea de escolarizante remite a una impronta pedagógica asida a los modos tradicionales de enseñanza en las instituciones educativas. Esta impronta es aprehendida por las docentes, no sólo a partir del proceso de formación docente, sino también a partir del recuerdo de su propia experiencia como alumna o alumno. Por ello es que los usos y sentidos en torno a los textos literarios, de los cuales las docentes son portadoras, se encuentran condicionados por su formación y por su propia trayectoria como lector -particularmente de literatura-, la cual se encuentra mayoritariamente asociada al inicio del tránsito escolar.

Es menester señalar que al hablar de planes de fomento de la lectura, inevitable es hacer referencia a la política educativa como escenario atravesado por las directrices de la política cultural. La tensión entre política educativa y política cultural es una discusión que 
merece ser sostenida en el nivel de la problematicidad, en tanto la educación es concebida como un valor y un derecho mientras que la cultura artística es percibida como factor de distinción, jugándose ello en la reproducción de las desigualdades sociales materiales preexistentes (Gayo y otros; 2011: 5).

Desde los aportes de Patte (1998: 157), invitar a las niñas y a los niños a abrir las puertas del juego verbal implica constituir un espacio que no sólo los convierta en propietarios o usuarios del lenguaje, reduciendo a este último a mero instrumento para incorporarse al mundo, sino como una herramienta para crear e inventar realidades (Barthes; 1993: 102). Y justamente porque el lenguaje no puede reducirse a un mero instrumento, sino que tiene correlato con nuestra construcción como sujetos parlantes (Petit; 2003: 73), interesa situar la función social del lenguaje poético.

Pizarro (2008: 38-41), sostiene que lo literario juega:

- con la polisemia, ya que reniega de la univocidad jugando, al decir de Eco, con la pluralidad de significados que conviven en un solo significante.

- con la ficcionalidad, ya que es creación de un mundo imaginario, el cual puede pertenecer al plano de la realidad o de la fantasía, pero que no constituye evasión del propio mundo sino posibilidad para introducirnos en él de manera diferente (Petit; 2001: 57).

- con la instrumentalidad del propio lenguaje, con la repetición que anticipa todo sentido y naturaliza la realidad. El lenguaje poético se recorta contra el lenguaje corriente, ya que su proximidad con el juego vuelve extraño al lenguaje, que no comunica sino pura intención de jugar (Alvarado y Guido; 1993: 8).

- si la literatura, al decir de Chambers (2008: 23), crea necesidades y deseos que antes no existían, permitiendo re-imaginar las instituciones, los individuos y los lenguajes de la vida cotidiana (Lerer; ibídem: 63), no puede desconocerse la potencialidad del lenguaje poético para acompañar a las niñas y a los niños en el ejercicio de los derechos de ciudadanía en el campo social y en su participación en la aventura cultural (Aulagnier, citada en DGCyE; 2001).

Esta demarcación teórica requiere ser situada dado el carácter complejo y múltiple de las representaciones y prácticas que, mediatizadas por la acción de los agentes escolares, promueven un juego de asociaciones y disociaciones que configuran el territorio de lo posible en un contexto institucional determinado (Rancière; ibídem: 23-52) que, a su vez, condiciona el vínculo entre escuela y literatura. 


\section{La Promoción de la lectura desde el referencial de la política pública.}

Se propone, en este apartado, una lectura en clave descriptivo-analítica para comprender la procesualidad que habilita la instalación del debate en torno a la distribución y apropiación de bienes artísticos y culturales en la agenda pública de nuestro país. Se aborda dicha institucionalización a la luz -y a la sombra- de los procesos de transición y consolidación democrática, a la vez que se profundiza en el vínculo entre la política de promoción de la lectura y la política educativa.

Desde el año 2004, trece países iberoamericanos inician un proceso de consolidación y fortalecimiento de sus políticas públicas en materia de promoción del libro y la lectura, además de articular acciones con escenarios estratégicos tales como las bibliotecas públicas y escolares. Dicha experiencia fue motorizada por un encargo efectuado al Centro Regional para el fomento del Libro en América Latina y el Caribe (CERLALC) y a la Organización de Estados Iberoamericanos (OEI), en el marco de la IV Conferencia Iberoamericana de Cultura (Octubre, 2002).

La conjunción de dichos organismos instituyó el Plan Iberoamericano ILÍMITA y la realización de diversos eventos y estudios sobre comportamientos lectores. Ello significó acompañar la iniciativa de los países miembro proponiendo objetivos y líneas de acción para configurar, a partir de las particularidades de cada uno de ellos, una política nacional de lectura $^{17}$. En la actualidad, son miembros del CERLALC todos los países iberoamericanos y del Caribe, de lenguas hispano-lusitana, siendo Portugal el último país en adherir en el año 2005. El núcleo fuerte de integrantes del Centro se concentra en aquellas instituciones y personas ligadas al mercado del libro (Ceretta; 2010: 82).

Subyace, en la adhesión a las directrices del Plan Iberoamericano ILÍMITA, la intención de que no se objetive una respuesta programática de carácter coyuntural -en correlato con un gobierno particular-, sino que se consolide una respuesta estratégica para fortalecer la accesibilidad a los bienes culturales. Ello supone garantizar, tanto la existencia de materiales -el objeto libro-, como así también la capacitación de actores-mediadores que instituyan nuevos espacios para la lectura y/o que fortalezcan o resignifiquen los espacios ya existentes.

\footnotetext{
${ }^{17}$ Los primeros países en implementar las recomendaciones efectuadas por el Plan ILÍMITA fueron: Argentina, Brasil, Colombia, Cuba, Ecuador, El Salvador, España, México, Venezuela.
} 
Según el informe del CERLALC del año 2006, titulado "Hábitos de lectura y consumo de libros", la población lectora en América Latina, comparativamente, ubica a Argentina en primer lugar (71\%), luego México (60\%), Uruguay (57\%), Colombia (45\%), Portugal (41\%) y, finalmente, Chile (40\%) (CNCA; 2006). Asimismo, si se conjugan los datos anteriormente referidos con los resultados del estudio de Tenti Fanfani (2005), titulado "La condición docente: análisis comparado de la Argentina, Brasil, Perú y Uruguay", la realidad en torno a las prácticas y consumos culturales, particularmente literarios, brindan otro diagnóstico y configuran una problemática distinta. En efecto, en el estudio de referencia se cuantifica que en Argentina sólo 7 de cada 10 docentes compran libros ocasionalmente y que sólo 4 de cada 10 lo hacen habitualmente. A su vez, un dato significativo es que el $47,9 \%$ de docentes encuestados expresa, en la categoría "alguna vez en el pasado/nunca", ha leído literatura de ficción (Ferreyro y Stramiello; 2008). Estos datos remiten a la compra de textos no escolares, lo que ofrece algunas líneas para problematizar la constitución del docente como lector de ficción y no sólo a establecer un análisis de la capacidad o interés por consumir (comprar) libros.

Se debe tener presente que la exposición de estos datos es expresión del interés de los Estados por cuantificar prácticas cuya complejidad no es susceptible de medición, en tanto la relevancia de la realización de prácticas de lectura radica en los significados que estas adquieren para los sujetos en el marco de su vida cotidiana. A su vez, las estadísticas elaboradas por diferentes organismos públicos y privados intentan capturar, por ejemplo, las prácticas de lectura efectivizadas durante el tiempo libre de los sujetos, lo que explicita el interés por trascender el escenario escolar como espacio único de realización de prácticas lectoras. Y, también, identificar cuántas personas leen por placer, cuántas personas acceden al libro a través de la compra, entre otros lineamientos que permiten objetivar, con dependencia de la metodología implementada, los hábitos lectores de la población de un determinado país o región.

Tales mediciones, atravesadas por variables tales como el género, el nivel educativo, la etnia, entre otras, permiten visibilizar que la relación entre democracia y exclusión no es novedosa sino que, siguiendo a Ansaldi (2007), la desigualdad no puede reducirse sólo a la dimensión económica, esa que se mide según la participación en la distribución de los ingresos. No pueden soslayarse la dimensión social y cultural, a menudo más difíciles de medir que la económica.

En esta articulación compleja entre democracia y exclusión vale referir que la universalidad de recursos no implica, mecánicamente, universalidad de derechos; a la vez que universalidad de derechos no implica, tampoco, universalidad de recursos. Se asienta así la 
importancia de identificar las lógicas que permean todas las relaciones sociales y que, en tanto materialidades, ordenan el mundo, generando normas y principios que naturalizan la desigualdad, incluso al reducir su explicación a la variable económica: desestimando así la función prioritaria de las ideologías en el sostenimiento de "lo dado".

La incorporación del derecho a la lectura en la agenda pública del Estado amplía el espacio de la representación simbólica, al reconocer como derechos inalienables el acceso a los libros y a la lectura. En torno a los fundamentos que orientan la formulación de dichas propuestas programáticas se ubican, por un lado, los diagnósticos alarmantes sobre la situación de lectura en los países latinoamericanos: que se lee poco, que se lee mal, que sólo se lee para estudiar, casi nunca por placer. Por otro lado, existe todo un imaginario que performa las políticas de fomento de la lectura, particularmente literaria, reconociéndola como una práctica social históricamente situada y como una herramienta que contribuye a mejorar las condiciones de existencia de sujetos y grupos. Existe una tercera tendencia que fundamenta la relevancia del acceso a los bienes culturales, pero remarcando la importancia de la participación del sector privado y la ampliación de las industrias culturales. Aquí se hace necesario prestar particular atención a las premisas que formulan una política de promoción mercantilizada del libro y de la lectura, en detrimento de garantizar su acceso en términos de derecho ciudadano.

En el caso argentino, el proceso de constitución de una política pública en materia de promoción del libro, la lectura y la literatura se inicia en el período post dictadura. Sin embargo, las bibliotecas populares argentinas son el movimiento ciudadano más antiguo de América Latina que ha desarrollado un trabajo sistemático en promoción de la lectura desde 1870 (Gutiérrez y Romero; 1989; Ramos Curd, 2009). En este sentido, el proyecto de conformación del Estado-nación en nuestro país instrumentalizó como herramienta para tal fin la Comisión Nacional Protectora de Bibliotecas Populares (CONABIP). Este organismo acompañó la iniciativa de sectores populares de formar bibliotecas, las cuales ejercieron un papel positivo en la ampliación del público lector, en la orientación de sus gustos e intereses, en la conformación de su sensibilidad (Romero; 1990: 41).

La constitución de la matriz de una política pública cultural en torno a los libros y la lectura se concretó al interior de varios procesos políticos y sociales, tales como el advenimiento de la democracia, la implantación de la educación pública, el incremento notable de la urbanización y la alfabetización masivas, y el surgimiento, para acompañar y sostener estos cambios profundos, de la biblioteca pública como un pilar de autoformación y de movilidad social (Parada; 2007: 27). 
Interesa señalar que la implicación de las acciones de la red de bibliotecas populares al proyecto de homogenización cultural en correlato con la conformación del Estado-nación, hace necesaria la construcción de una mirada en torno a los sectores populares que, por un lado, aprehenda su situación subordinada y conflictiva y que, por otro lado, conciba la hegemonía que sobre ella se construye, antes que como una regimentación total, como el límite, el marco para un disenso no eliminable (Romero; ibídem: 60-61).

Este carácter tensional que configura el acceso a los bienes culturales y artísticos atraviesa el proceso histórico en materia de promoción de la lectura, ya que la alfabetización tanto en América Latina como en Europa- fue el requisito para el reconocimiento ciudadano, en articulación con la difusión del proyecto político republicano como salvación y de la preocupación por la futura inserción laboral de amplias capas poblacionales (Chartier; 2004).

Lo anteriormente explicitado contribuye a reconocer, siguiendo a Chartier (ibidem; 36), que la obligación de educarse ya no es un proyecto extensivo a la vida humana sino únicamente a la vida activa y esta se confunde con el tiempo de trabajo. Esta referencia permite situar que, desde sus inicios, la promoción de la lectura estuvo comprometida con una formación moral basada en los ideales civilizatorios de occidente, netamente instrumental y que participó del juego generacional, separando a los padres inmigrantes de los hijos argentinos, situación que se acrecentó por la instrucción, la alfabetización y la asimilación de principios, ideas y valores ajenos a ella (Romero; ibídem: 42).

De este modo las instituciones escolares devinieron, para Marc Soriano (ibídem: 385), en la amalgama de dos inculturas: la del pueblo, por su condición social y la de la infancia, debido a su edad. Así es que cuando el origen de la literatura infantil se sitúa en la expropiación adulta de las historias que gustaban a los chicos para devolvérselas "adaptadas" (Massat y Alvarado; 1993: 30) puede evidenciarse, por ejemplo, cómo la fábula esópica fue una forma literaria concebida para constreñir los comportamientos insumisos y para modelar la vida del niño de manera acorde con las normas cívicas (Lerer; 2009: 85).

Puede considerarse entonces que la literatura se adaptó funcionalmente a los objetivos de las instituciones escolares, favoreciendo esta orgánica implicación que las prácticas de lectura fueran identificadas, por legos y expertos, como el mejor vehículo para transmitir el conocimiento, sin que ella se convirtiera en un objeto de conocimiento (Bahloul; 2007: 7). Ello destituyó la posibilidad de analizar las prácticas de lectura, particularmente literarias, desde las apropiaciones materiales y simbólicas construidas por las niñas y los niños. En este sentido, se invisibilizó la potencialidad de la infancia de resistirse ante la visión de mundo y de los significados adultos construidos en torno a ciertos objetos, cancelando un sentido en torno a 
la literatura infantil que, en detrimento de concebir a la infancia como público, reconociera su potencialidad semántica, su "poder-defenderse" de esa literatura edificante (Rodari; 1993: 62).

Siguiendo los planteos de Andruetto (2009: 25), durante la década de 1980, el problema que estructuraba el campo de quienes promovían la literatura infantil y juvenil era su instalación en las escuelas y la creación de hábitos lectores, sembrando esa conciencia en los docentes como actores estratégicos para recuperar a dicha institución del cautiverio impuesto por el mercado editorial. Posteriormente al 2001, se percibe un incremento del interés académico, un conocimiento de la crítica especializada y el nacimiento de pequeños (y de capitales nacionales) emprendimientos editoriales (Andruetto; ibídem: 10).

Las transformaciones operadas en el campo de la literatura infantil y juvenil, que se inician a mediados de la década de 1970, pero que en nuestro país se verán obturadas por la dictadura militar, se materializaron sobre una serie de condiciones asociadas a la incipiente conquista del derecho del niño a ocupar un espacio en los sistemas culturales, la irrupción de autores con una sólida formación humanística y una visión contemporánea del oficio de escribir para niños (Rodríguez; 2010).

En el caso argentino, muchos escritores del campo de la literatura infantil y juvenil provenían del campo educativo, desempeñándose como docentes. Este dato es relevante en tanto establece nuevos parámetros para acercar la literatura a los sujetos concretos, no ya desde el didactismo sino desde una perspectiva próxima a la premisa que estructura la promoción de la lectura literaria, es decir, favoreciendo el disfrute estético del lenguaje. Para ejemplificar esta cuestión, interesaba no lograr solamente que un niño distinguiera una narración de una copla, sino generar un espacio en el que haya experimentación con la palabra, exploración de cada niño en sí mismo y también construir relaciones entre palabras y otras formas de expresión (Pizarro; ibídem: 50).

Por ello cobra sentido que el primer referencial de política de Estado en materia de promoción de lectura en nuestro país durante el período 1986-1989 bajo el nombre "Leer es crecer", desacralizara la lectura de los ámbitos formales cuyo epítome era representado por las escuelas y bibliotecas. Sin embargo, la indefinición del Plan como política cultural o educativa se erigió en un obstáculo para pensar al sujeto destinatario de las intervenciones, lo cual devino en acciones concentradas en instancias de trabajo que, desde la modalidad taller, homogeneizaban intereses y necesidades particulares de los grupos que solicitaban los servicios brindados por dicho plan (Mihal; 2011).

El Plan Nacional de Lectura re-lanzado en 2003, luego de una breve existencia en el año 2000-2001, recupera la tensión que opera como sustrato en la configuración de una 
política de lectura: a saber, su definición como política cultural o como política educativa (Mihal; ibidem). Es así que desde el Ministerio de Educación de la Nación se abordó la esfera cultural -en sentido amplio-, a través de la difusión gratuita de materiales de lectura: en espacios estratégicos - canchas de fútbol, por ejemplo- e involucrando agentes mediadores novedosos - como peluqueros-, apelando a materiales de impresión de bajo costo pero sin reducir su calidad y estética.

Por otra parte, las acciones en torno a la esfera educativa involucraron a todos los niveles -desde educación inicial hasta el nivel terciario-, comprometiendo los siguientes lineamientos temáticos ${ }^{18}$ : 1) el docente como lector; 2) el docente como mediador; 3) literatura infantil; 4) narración oral; 5) la lectura en contextos de diversidad lingüística.

A partir de estas referencias se puede visibilizar la materialización de una política pública de promoción de la lectura que articula acciones orientadas a la difusión y acceso al objeto-libro y que, simultáneamente, favorece que sujetos y grupos puedan representarse la lectura y los libros como un derecho. En este sentido, las intervenciones se orientan a constituir una comunidad de lectores, a partir de operaciones concretas en ámbitos escolares y extra-escolares.

En el año 2008 surge el Plan Nacional Lectura, unificando las acciones desarrolladas por la Campaña Nacional de Lectura y el Plan Nacional de Lectura, articulándose con la Ley de Educación Nacional 26.206, con una fuerte impronta vinculada a la construcción de ciudadanía. Así es que con el objeto de federalizar estrategias y el diseño de políticas educativas de lectura, los 24 Planes de Lectura dependientes de los ministerios provinciales coordinan acciones junto al Plan Nacional de Lectura del Ministerio de Educación de la Nación, a través de cinco Coordinaciones Regionales ${ }^{19}$.

De esta manera, podría referirse que la cristalización de una política pública en materia de promoción de la lectura se configura a partir del Plan Nacional Lectura, el Consejo Nacional de Lectura y la Encuesta Nacional de Lectura. La constitución inter-ministerial del Consejo Nacional de Lectura, junto a otros organismos públicos, se orienta a promover la relevancia de la lectura y su reconocimiento en la agenda pública de Estado. También se responsabiliza de la efectivización de otras acciones afines tales como, por ejemplo, la realización de una Encuesta Nacional de Hábitos Lectores (cuyo antecedente último remite al año 2001).

\footnotetext{
18 Publicación electrónica en http://planlectura.educ.ar/listar.php?menu=1\&submenu=3

${ }^{19}$ Publicación electrónica en $\underline{\mathrm{http}: / / \text { planlectura.educ.ar/pdf/Bibliotecas Argentina.pdf }}$
} 
En la actualidad se están socializando los resultados del trabajo realizado en el período 2010-2011, el cual contempló los indicadores de medición de la encuesta última, con la intención de establecer comparaciones pero, por vez primera, involucrando la franja etaria que va desde los 12 a los 18 años. La producción de datos en torno a dicha franja etaria puede complementarse, específicamente, con los resultados desarrollados a partir de la investigación sobre la situación de las bibliotecas escolares del país, iniciativa consensuada con la Comisión de Expertos en Lectura y Bibliotecas de la OEI y realizada conjuntamente en Brasil, Chile y $\operatorname{México~}^{20}$.

Sin embargo, pese a que en Argentina la política de promoción de la lectura se moldea desde los ejes de transversalidad y universalidad, la lectura $-\mathrm{y}$ particularmente la lectura literaria-, parecen estar en crisis. Una crisis que se expresa cualitativamente: "los alumnos leen mal", y cuantitativamente: "los alumnos leen poco porque los padres no leen nada". Una crisis que, al producir un desorden en el estado de cosas, nos fuerza a buscar culpables inmediatos: "la gente lee poco culpa de las nuevas tecnologías". O bien a culpar, indistintamente, a la pobreza o a los pobres: "los chicos de barrios carenciados tiene más dificultades para aprender a leer por las desigualdades de clase",21.

A partir de lo anteriormente expuesto, interesa reconocer la importancia de la investigación y análisis de las políticas culturales, particularmente las referidas al fomento lector, al decir de Stompka (citado por Ansaldi; 2010: 208), como un elemento constitutivo de un conjunto de oportunidades, recursos, facilidades, "materias primas" para que los sujetos construyan la realidad social. Ello habilita un análisis en pos de identificar situaciones estratégicas que contribuyan a abreviar las desigualdades -no sólo económicas-, atendiendo a los procesos de democratización, a las formas de distribución de capitales diversos que habilitan posiciones ciudadanas diversas y divergentes.

Atender a las condiciones de posibilidad y realización del régimen democrático (Ansaldi y Giordano; 2012: 505), contribuye a conceptualizar los planes de fomento lector como una política macro cuyo sentido se suspende -relativamente-, al ser apropiada por los agentes sociales en el espacio del propio cotidiano. Si bien el paradigma de derechos ha devenido hegemónico e, incluso, cuestión de Estado (Ansaldi y Giordano; ibídem: 640), la

\footnotetext{
${ }^{20}$ Publicación electrónica en http://www.me.gov.ar/curriform/masplectura2 b.html

21 Es menester señalar respecto a los diagnósticos alarmantes y fatalistas en torno a la situación de lectura en los diferentes países de la región, que sólo el plan de Argentina cuestiona la homogeneización de los estudios cuantitativos (por ejemplo, PISA21), bregando por la construcción de datos que, al decir de Bombini (2008), no asuman la forma de la estadística sino la de la narrativa.
} 
importancia de analizar las prácticas concretas nos sitúa en el desafío de conjugar inclusión con calidad y acceso material con posibilidad de apropiación.

Es indelegable la función política de los Estados de garantizar la gratuidad en el acceso a los bienes artísticos y culturales, sobre todo a aquellos sectores que no pueden acceder a través del mercado, convirtiendo en un lujo el acceso a los libros, la lectura y la literatura.

De todos modos, la configuración de una política pública en materia de fomento lector, de producción y distribución de bienes artísticos y culturales y de mejoramiento de la calidad educativa, no reduce per sé las desigualdades producidas por factores no necesariamente ligados a la variable ingresos. Por ello, pensar la lectura como un asunto de política pública requiere una reflexión sobre los cambios que afectan los sistemas de representación (CERLALC-OEI; 2004) a través de los cuales nos vinculamos con los libros, la lectura y la literatura

Ahora bien, la inscripción de la política cultural en la agenda pública re-sitúa la discusión en torno a las desigualdades y obstáculos que tensan el disfrute de los bienes artísticos y culturales por parte de las ciudadanas y los ciudadanos, al mismo tiempo que demanda un espacio de diálogo en torno a objetos comunes que instituye la cuestión de lo público, no como apelación a estados de ánimo individuales sino a los deberes de quienes formamos parte de una comunidad política (Garretón; 2012).

De ahí, la relevancia de analizar cualitativamente cómo los agentes institucionales (en las escuelas, en las bibliotecas públicas y populares, en los clubes, entre otros escenarios), legitiman o no el sistema democrático a partir de sus prácticas concretas. Porque, como escribió Gianni Rodari en el prólogo de Gramática de la fantasía, el uso total de la palabra para todos, me parece un buen lema, de bello sonido democrático. No para que todos sean artistas, sino para que nadie sea esclavo.

\section{Sumario del capítulo.}

En el presente capítulo se analizó la centralidad de las prácticas de lectura y escritura en las escuelas, a través de un recorrido histórico, en contraste con nuevas formas de concebir la alfabetización y, en particular, la lectura literaria. Se expusieron, también, las funciones del lenguaje poético en clara correspondencia con la definición explicitada en el diseño curricular actual. El desarrollo del concepto de transposición didáctica permitió instalar la idea 
provocadora de que la literatura no es enseñable y que la biografía lectora del docente y su formación y postura pedagógica condicionan el acceso de niñas y niños a la literatura.

Asimismo, se expuso la relación tensional entre política educativa y política cultural que permea la constitución y desarrollo de planes de fomento lector. Se identificaron actores, instituciones, dispositivos y formas diversas de conceptualizar el acto de la lectura y el valor de la literatura. También se hizo referencia a los escenarios escolares, en tanto escenarios estratégicos para el desarrollo de las premisas de la política en materia de promoción de los libros, la lectura y la literatura. Hacia el final del capítulo, brevemente, se expuso la relación entre la promoción de derechos culturales y su relevancia en la legitimación del orden democrático. 



\title{
Capítulo III: Las escuelas, los cronotopos, la lectura. Descripción de los contextos de interacción.
}

\author{
En nuestro jardín había un pabellón \\ abandonado amenazando ruina. Le tenía \\ cariño por sus ventanas de cristales \\ coloreados. Si pasaba la mano en su \\ interior me iba transformando de cristal a \\ cristal, tomando los colores del paisaje que \\ se veía en las ventanas, ahora llameante, \\ ahora polvoriento, ya ardiente, ya \\ exuberante. Lo mismo me sucedía cuando \\ pintaba en colores y se me abrían las cosas \\ en su seno, tan pronto que las llenaba con \\ una nube húmeda. Con las pompas de \\ jabón ocurría algo parecido. Viajaba con \\ ellas por la habitación metiéndome en el \\ juego de los colores de los globos hasta \\ que reventaban. Me perdía en los colores \\ por lo alto del cielo, lo mismo que en una \\ joya, en un libro; pues en todas partes los \\ niños son su presa
}


Walter Benjamin, Los colores ${ }^{22}$

\section{El espacio-tiempo en las instituciones educativas: de la escuela como objeto a las lógicas escolares.}

La estrategia expositiva que se desarrolla en este capítulo enfatiza la observación, el registro y la contextualización, a partir de la descripción densa de los escenarios escolares en los cuales desarrollé el trabajo etnográfico. A partir del relato de diferentes escenas de lectura y de la vida institucional de cada establecimiento educativo, se propone presentar a cada institución para, posteriormente, analizar las prácticas de lectura concretas: sus espacios y tiempos, sus agentes y, finalmente, sus condiciones de (im)posibilidad. Ello permitirá, hacia el cierre del capítulo, situar puntos de encuentro y diferencias entre las escuelas involucradas en el proceso de investigación.

Cada establecimiento es presentado a través de un subtítulo que, de alguna manera, fue construido como respuesta ante la pregunta: ¿cómo se lee literatura en cada una de las escuelas entrevistadas?

\section{Escuela "A".}

Capitales familiares y escolares en la formación literaria: cuando los adultos acompañan el recorrido de niñas y niños por la lectura

Concurrí al establecimiento en dos oportunidades para entrevistar a las maestras de grado, a la bibliotecaria escolar y a la docente designada para atender en contra-turno el espacio de biblioteca, quien se encontraba con tareas pasivas.

Si en algo coinciden las docentes entrevistadas es en la caracterización del acerbo bibliográfico existente: escasos títulos, pocos ejemplares. También hubo quienes refirieron que sería importante pensar en la calidad de los textos: pensar en libros de autores reconocidos, no necesariamente los considerados canónicos y, a la vez, distanciarse de aquella literatura de colección, simplificadora de los relatos. A su vez, reconocían que el mercado editorial producía libros lindos.

\footnotetext{
${ }^{22}$ Benjamin, Walter (1982). Infancia en Berlín, Argentina, Alfaguara.
} 
En el espacio de biblioteca escolar se realiza un taller de informática dictado por el padre de uno de los alumnos, con una carga horaria de 6 horas semanales, consensuado por la comunidad educativa como proyecto institucional. Ello restringe las posibilidades de concretar situaciones de trabajo en torno a la lectura de literatura o trabajos de investigación, ya que el dictado del curso referido afecta seis horas semanales. En este contexto, la Inspectora de Primaria organizó un itinerario para que sea la bibliotecaria escolar quien concurra a las aulas para realizar situaciones de lectura y escritura, compensando el tiempo afectado por el curso mencionado. La concurrencia a la biblioteca escolar se encuentra condicionada, en el caso del turno tarde, porque no siempre se encuentra la persona a cargo o porque se evita que las niñas y los niños concurran por su propia cuenta, ya que en la planta alta donde se ubica la biblioteca, también hay aulas destinadas a jóvenes cursando el nivel secundario.

Entre la bibliotecaria y las maestras de grado, la relación está en proceso de construcción. Diferencias que imposibilitan el trabajo articulado. En la situación del turno mañana, existen divergencias claras entre maestras de grado con una amplia implementación de las prescripciones curriculares, constructoras de situaciones de lectura promovidas por la asignatura Prácticas del Lenguaje. Estas docentes discuten, no siempre de modo explícito, con la bibliotecaria, quien promueve la realización de una campaña de salud buco-dental, como proyecto enmarcado en su espacio de trabajo.

Mientras tanto, la bibliotecaria mencionada realiza sola un taller de lectura con los niños, comentando: "me gustaría que la docente se quede, que no lo tome como hora libre". Las maestras de grado, mientras ven coartado el vínculo con el personal a cargo de la biblioteca prefieren evitar el vínculo con esta última: “... por ahora los libros los traigo de la biblioteca de mi casa”.

Por otro lado, los referentes familiares de las niñas y niños acompañan el proceso educativo: se acercan a conversar con las maestras de grado, incluso alguna de ellas propuso una valija viajera para que recorra los hogares de sus alumnos, incorporando material exclusivo para los padres: un libro con personajes de dibujos infantiles y de tiras cómicas de antaño y bibliografía para orientar la crianza: autores de la talla de Tonnucci, por ejemplo. También vale referir la situación de una docente que se encuentra educando a los hijos de quienes fueron sus alumnos, lo cual favorece el diálogo en torno a ciertas dificultades relacionadas con la crianza de los niños. "Padres que reconocen no dedicar tiempo para la lectura por falta de tiempo, porque están cansados después del trabajo", relataba la maestra al pensar la formación de lectores en su vinculación con aquellos mediadores "naturales", que serían los integrantes de las familias.

Sin embargo, las docentes refieren que hay un acompañamiento por parte de los adultos, que se preocupan porque sus hijos asistan con los materiales requeridos. La población 
que asiste se corresponde con un nivel socio-económico medio, lo cual tiene incidencia en la inexistencia de situaciones de ausentismo prolongado ni de repitencia. El capital escolar, además, se complementa con otros capitales brindados por la familia y reconocidos por las docentes entrevistadas: los padres estimulan, compran libros a sus hijos, son escasas las familias que no cuentan con acceso a Internet.

Las maestras refieren ser lectoras de literatura y de otros textos, y enumeran durante la situación de entrevista los autores que han leído. Organizan, desde el primer encuentro del ciclo lectivo, los proyectos que se realizarán en cada grado. Se intenta que los distintos niveles aborden diferentes textos y géneros, por lo que la voluntad del docente, es decir, su responsabilidad para con la concreción de la propuesta y, antes, su propia relación con la literatura, es un factor decisivo en la constitución de niñas y niños como lectores competentes: "Acá se sabe a quién le gusta la literatura y a quién no, asi que de antemano se sabe qué proyectos serán efectivamente concretados", clarifica una docente.

También reconocen que las niñas y los niños tienen interés por la lectura, si bien afirman que ha habido cambios que afectaron tanto la frecuencia de las prácticas de lectura literaria como la disminución del valor por dicha práctica, y que las falencias en la lectura suelen "ser tremendas". Pero pareciera que en esas afirmaciones se refieren a cierta representación de la sociedad en general y no específicamente al entramado micro-social en el cual se inscriben: no hay quejas en torno a la población que reciben y se sienten a gusto con el grupo de estudiantes que tienen a cargo: "... porque creo que si los padres no le bubieran dado libros, los chicos mismos lo hubieran demandado, lo hubieran buscado".

\section{Escuela "B".}

Cuando el disciplinamiento prima sobre la constitución de hábitos: las prácticas de lectura posibles en instituciones sin orden o sin-sentido del orden.

Después de conversar con la Directora del establecimiento y tener el permiso para realizar las entrevistas, la misma me invitó a realizar un recorrido por la institución. Me cuenta de la conflictividad de los niños, que está trabajando la situación de un chico muy violento. Que la Inspectora a cargo del Equipo de Orientación Escolar participa de la estrategia para resolver el problema, que se ha hablado con la madre para que vigile al niño a través del vidrio de la puerta, que sólo ingrese al salón si ve que su hijo no se concentra en la actividad propuesta o agrede a alguno de sus compañeros. "Ya no sabemos qué hacer, y está la Inspectora, pero lo que ella propone tampoco resuelve". 
Asistí repetidas veces a la institución, dado que nunca encontraba en el turno tarde a las maestras. Me dijeron algunas docentes que me convenía más el turno mañana, porque estaba la Vice-directora y la dinámica estaba más organizada. Más de un grado, simultáneamente, solía estar sin docente a cargo en el turno vespertino. Los grupos eran reubicados en función de los docentes efectivamente disponibles, lo cual significaba afectar las horas especiales de algunos maestros. También la Directora solía hacerse cargo de algún grupo, pero no se proponía actividad alguna. Muchos de los niños salían del aula, a espaldas del directivo; también estaban los que desautorizaban sus señalamientos y órdenes: con muecas, pero también con indiferencia.

Luego de algunas conversaciones espontáneas sobre temas triviales con las docentes en la puerta de entrada de la institución, durante el horario de ingreso de los niños a la institución, las mismas expresaron: "Esto es un lio siempre, no te deja trabajar (...). La Directora le está haciendo mal a la institución, porque vos no podés andar gritándoles a los chicos porque corren (...). Acá le propuse (a la Directora) hacer rayuelas gigantes en el patio, para organizarles un espacio de juego. Me dijo que escribiera un proyecto. No podía creer que necesitaba escribir un proyecto para bacer algo para que los pibes jueguen durante el recreo".

Muchas docentes refirieron estar cansadas por la escasa claridad de las directrices de la Directora, sumado a situaciones en el grado inicial que requieren de abordajes profesionales. Pero los profesionales del Equipo de Orientación Escolar, según expresión de la psicóloga: "No estamos para escuchar al chico, sino para contenerlo". Esa fue la respuesta que recibí cuando tuve la oportunidad de conversar, invitado por la misma Directora, con los integrantes del Equipo sobre una "caso difícil" que "altera a toda la institución, porque es un cbico muy violento, le pegó hasta una auxiliar", relató la maestra a cargo.

Fue imposible en la institución disponer de la hora especial de algún maestro para efectuar una entrevista, ya que debían cederla para el cuidado de algún grupo de niños debido a la inasistencia de la maestra a cargo. Y en la oportunidad que tuve de presentarme ante la maestra de $1^{\text {er }}$ año, la necesidad de la misma de conversar sobre la problemática con uno de los niños, primó sobre los objetivos que orientaban mi presencia allí.

En lo que respecta a la formación de lectores y al vínculo particular con la literatura, la bibliotecaria escolar del turno tarde refiere que ha elaborado proyectos para trabajar con diferentes años pero que “... por una cosa u otra se suspenden”. Y agrega: "La señorita tiene ya clarito que el taller que hacemos acá no es hora especial para ella: sabe que tiene que estar". Refiere que no participa del armado del proyecto, que esa tarea la realiza la docente, que la Dirección lo visa y 
que ella lo implementa. "Tampoco lei el diseño curricular, te soy sincera. El otro día lo agarré porque llegaron libros nuevos de Nación y me puse a ver cuántos estaban en la lista de recomendaciones".

En una de las últimas visitas que realicé a la institución, sentado en el banco de la galería, a mi izquierda, donde comienza el pasillo que da hacia los salones del primer ciclo, observo a una mujer en la puerta de una de las aulas. La mujer mira a través de los vidrios de la puerta hacia el interior del aula, parándose en puntas de pie, como intentando llegar con su mirada hacia el fondo del salón. Recuerdo: es la madre del niño que, según la psicóloga del Equipo de Orientación Escolar, no se puede contener y que fuera ubicada por la Inspectora en esa posición de vigilancia.

A los pocos minutos se abre la puerta y un niño empieza a gritarle a la mujer: - “Sali! ;Andate! ¡No te quiero!”-. Y el niño vuelve a entrar a la clase, dando un portazo que quiebra el silencio y la calma relativa del establecimiento.

La mujer, que había retrocedido unos pasos, se vuelve a ubicar como observadora a través del vidrio de la puerta. $\mathrm{Al}$ rato, la mujer da media vuelta y se aleja de la puerta. Inmediatamente sale la maestra del aula y llama a la mujer:

- "Mamá, ahora no te vayas que le está pegando a los otros nenes. Ahora es cuando tenés que quedarte y poner límite"-, informa la docente a la mujer.

Y la mujer responde:

- "Yo no voy a hacer tu trabajo"-. Y la maestra se queda callada y camina hasta atravesar la puerta de la dirección que se encuentra frente al aula.

Sale la maestra acompañada por la Directora, informándole a la madre del niño que la acompañe a su escritorio. El niño también sale a la galería y se acerca a su madre, golpeándole con sus manos el estómago:

- "Te odio, andate!"- repite el niño, pero ahora llorando. Y vuelve a entrar al salón después de su maestra. Y cierra la puerta con un fuerte golpe.

La maestra ha llamado a la Directora. La directora ingresa a su oficina, junto a la madre.

"Me encanta esta Directora", me comentó la mamá de un niño que refiere que los directivos del establecimiento al que anteriormente concurría le dijeron que ya no podía asistir "... porque no quiere escribir". "Yo elegí traerlo acá, me parece la mejor escuela, porque la Directora los tiene a todos cortito", finaliza.

\section{La escuela "C".}

La importancia de los mediadores, la lectura poética como potencia para pensar el cotidiano.

"En 8 horas podemos darnos el gusto de disfrutar de la literatura", dice la maestra de $1^{\circ}$ año, reconociendo en esa frase la importancia de disponer de tiempo para que el lenguaje poético exista en el cotidiano de niñas y niños. La institución educativa es de jornada doble, de gestión estatal, instalada en una zona con población socio-económicamente vulnerable y con evidentes situaciones de violencia intra-familiar. "Cada familia es un mundo, acompaña poco (...) pero en el caso de literatura, por ejemplo, algunos no tienen cuentos en la casa siquiera", refiere la misma docente.

Más allá de las carencias en esta institución se permiten trabajar en equipo, con la Directora, la Bibliotecaria Escolar y otras maestras, así como introducir innovaciones y 
proponer actividades que habiliten e incentiven la lectura literaria. "Acá la Directora nos propuso trabajar en "parejas pedagógicas", que es una propuesta novedosa, avalada por Educación (...). La Directora conoce muy bien el diseño curricular, así que nos orienta, diciéndonos qué está permitido (...). Imaginate que tengo más de 20 años de servicio: ¿sabés cómo me cuestan los cambios? Pero trabajando fuera de la biblioteca... eso ayudó a que los chicos me reconocieran como docente y que la misma docente, me reconociera como compañera y como un recurso para ayudar en el aprendizaje de los chicos", refiere la docente a cargo del espacio de biblioteca.

Concurrí en dos oportunidades a esta institución para realizar las entrevistas. En ambas oportunidades había exposiciones abiertas a la comunidad con producciones realizadas por los alumnos. También cuentan con la visita de un grupo de cuenta-cuentos de la comunidad, integrada por adultos mayores.

"Te das cuenta cómo los chicos van haciendo hábitos con la lectura: en la Maratón de Lectura estaban todos acostados sobre colchonetitas en el Salón de Usos Múltiples, van a biblioteca algunos, por supuesto no todos, y conversan con la Bibliotecaria sobre lo que están leyendo...". Agrega la Bibliotecaria: "En la actualidad, tenemos 300 préstamos en libros. Sólo en primario. Eso es significativo me parece".

Con alumnos de $4^{\text {to }}$ año generaron una votación para seleccionar un cuento que sería dramatizado por ellos. Se confeccionaron las boletas, fue una elección, como las presidenciales. Tan similares a las elecciones de nuestros representantes que una niña, al reparar en la escasez de votos del libro de su preferencia comparó: "Perdió como Duhalde", aunque en dicha institución, sede de los comicios, el candidato obtuvo la mayor parte de los votos.

Por supuesto los docentes reconocen dificultades en la tarea pero “... las vulnerabilidades las trabajamos acá adentro (refiriéndose al espacio de Dirección). Porque cuando salimos afuera, a las aulas, vamos a enseñar". La Directora expresa: "Logramos una comunicación muy importante, entre nosotras, con las familias. Si hay situaciones de violencia, tenés que trabajar desde la palabra. Por eso, escuchar a los chicos, tratar de entenderlos, de mirarlos. Aprender de ellos. Aprendemos si hay confianza en el otro.

Las problemáticas de ausentismo son escasas y, según refiere la Directora, “... la estructura del diseño curricular, al integrar contenidos, hace inevitable que un tema vuelva a ser mencionado, repasado (...) y si hay ausentismo es porque todavia no se ha conseguido un trabajo estable, la posibilidad de tener horarios, de estabilizarse. La mayoría de los padres son changarines".

Desde la institución visitan con frecuencia la Biblioteca Popular Pestalozzi. De hecho, representan la escuela con mayor número de visitas efectuadas durante el año 2012. Una de las voluntarias de la Biblioteca Pestalozzi me comentó que era notable el trabajo que los 
referentes escolares estaban haciendo puesto que, para fines de año, los chicos de $1^{\circ}$ año ya estaban leyendo palabras por su cuenta y que la maestra a cargo acompañaba esa actividad.

A fines del ciclo lectivo 2012, tuve la posibilidad de leer las producciones que niñas y niños realizan durante el tiempo de permanencia en la Biblioteca Popular, en el marco de visitas libres. Después de recorrer el almacén de libros, compartir algunas historias, generar alguna instancia de lectura personal, entre otras, se les propone escribir o dibujar, mientras se organiza el desayuno o la merienda. A veces se les entrega una imagen que funcione como disparador, la mayoría se resisten a escribir, sobre todo los años más avanzados. Leyendo esas historias, me encontré con la de una niña cursando el $6^{\text {to }}$ año en este establecimiento.

A continuación reproduzco sin modificaciones la historia elaborada por la alumna. Considero que dichos materiales constituyen insumos para problematizar el cotidiano, las relaciones genéricas, los afectos, a través de los relatos elaborados por sujetos, en su condición de niñas y niños. La imagen que se expone junto al texto producido por la niña fue el disparador a partir del cual escribió el relato, y corresponde a una ilustración del libro-álbum de Los misterios del señor Burdick, del autor Chris Van Allsburg (1997).

"Un día había un señor que se había casado con una señora, al pasar los años el señor que se llamaba Lucas empezó a consumir mucha bebida alcohólica y él empezó a volverse adicto, tenía muchos problemas y él a la señora le pegaba hasta que la señora lo mandó preso. Pero él se escapó fue a la casa y tomó y tomó la señora recién regresaba de hacer las compras y en ese momento la agarró de los pelos y la estampó contra la pared le pegó con un fierro y la mató después al otro día se lamentaba porque la había matado él como no aguantaba se lamentó un montón tomó y tomó se encerró en su casa ató las sábanas se la puso entre el cuello y se mató pero él antes de suicidarse puso a la mujer debajo de él para que caigan las lágrimas en ella para que vea que esas lágrimas son todo el amor que sintió por ella."

La densidad del relato construido por la niña nos enfrenta a situaciones de violencia de género: situaciones que actualmente pueden conceptualizarse como tales, producto del avance de la matriz legislativa y de las políticas orientadas a la desnaturalización de vínculos desubjetivantes.

Tomando distancia de una postura dramática interesa, a partir de la lectura de este relato, identificar recursos y herramientas que habiliten a niñas y niños transitar la escuela como un territorio de experiencia (Duschatzky; 2005), generando tensiones entre las cuestiones consideradas públicas y las consideradas privadas. Es decir, desnaturalizando 
formas de pensar los afectos para situarlos en estructuras complejas de poder explicitadas en la vida cotidiana ${ }^{23}$.

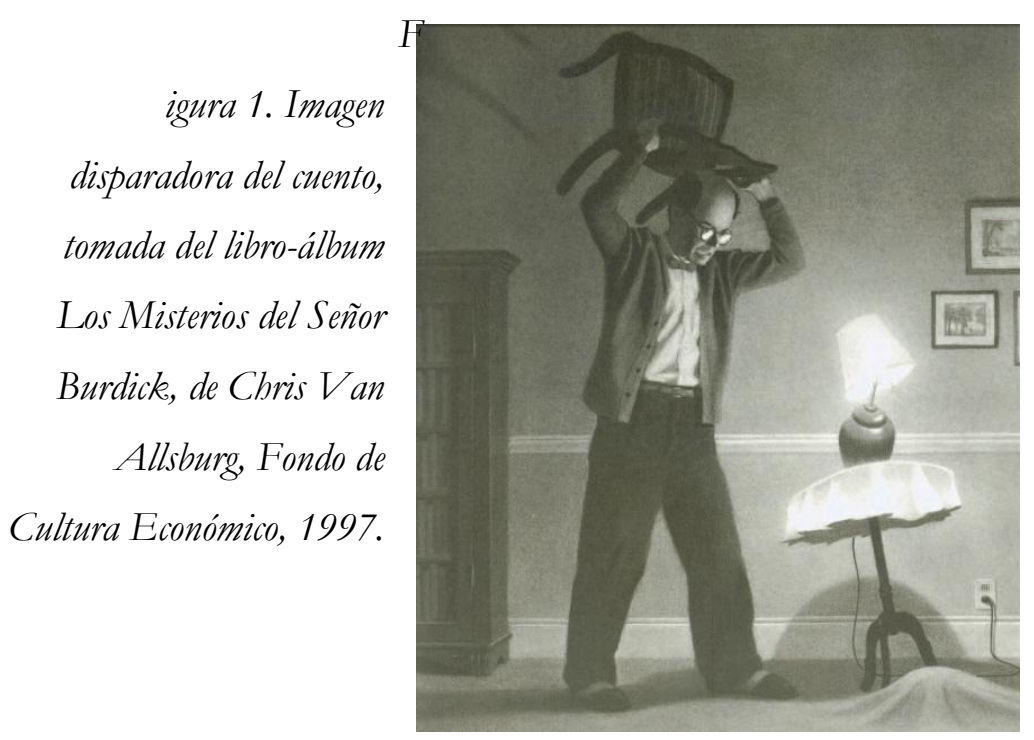

La escuela "D".

Cuando el bache no es sólo cultural: entre el abandono estatal y el desinterés docente.

Cuando me presenté ante la Directora para comentarle mis intereses en torno al proyecto de investigación, la misma refirió: "Hay un bache cultural muy importante".

${ }^{23}$ Es necesario aclarar que no se expone el relato elaborado por la niña como "prueba" o "evidencia" de que padece situaciones de violencia en su grupo familiar, ya que la relación entre escritura y experiencia cotidiana es, antes que lineal, compleja y multidimensional. Analizando producciones de otras niñas y niños que concurren al mismo establecimiento, se registraron historias donde se repite, en casi la totalidad de los relatos, situaciones violentas (robos, asesinatos). En contraste, producciones elaboradas por niñas y niños de otros establecimientos incorporan otras situaciones como tramas de su relato que no se basan en relaciones agresivas. 
En esta escuela recién se encuentra en proceso de armado el espacio de biblioteca. Recién, desde su implementación en el 2006, se están adaptando las prácticas de las maestras de grado a las prescripciones curriculares. En la reunión correspondiente al inicio del ciclo lectivo del año 2012, las docentes recién incorporadas y algunos auxiliares que participaron de la reunión se sorprendieron del drástico descenso de la matrícula promovido por el deterioro edilicio que no expresa sino el abandono del Estado en materia de sostenimiento de la calidad educativa.

El financiamiento que reciben del Programa Integral por la Igualdad Educativa ${ }^{24}$, favoreció la compra de material de plástica y dotación de libros para docentes y para cada alumno. Por otro lado, también se experimentó la ausencia de una comunidad educativa que contara con la presencia de algunos padres para llevar la contabilidad de las obras iniciadas para la refacción del edificio, para hacer transparente la cuestión.

"El establecimiento estaba deteriorado, los techos se caían, los baños... Se perdió mucha matrícula y ahora bay que promocionar la escuela, que está linda, que no es un peligro para los chicos. Los padres tenían miedo de traer a sus hijos", cuenta la Directora que se encuentra desempeñando dicho cargo recientemente, después de ejercer durante 4 años la docencia allí.

Cuentan con una extensión de Equipo de Orientación Escolar, es decir, un préstamo de profesionales que una escuela le brinda a otra, para la atención de situaciones de vulnerabilidad socio-educativa: una orientadora educacional, una orientadora social y una orientadora del aprendizaje que asisten una vez por semana. "Hay mucho trabajo de campo becho por los directivos y las maestras, que me acompañan en una hora libre o que por voluntad, antes o después de las clases, pasan por las casas de las familias”, explica la Directora. Y amplía: “... hacemos el seguimiento, un monitoreo desde el esfuerzo personal, para que el chico quede inserto en el sistema y para que puedan concluir sus estudios y acreditar terminalidad de nivel y, por supuesto, continuar. Los chicos que han sido enviados por problemas de conducta, repetidores... porque los padres no sienten un compromiso con la institución. Es una escolarización para cobrar la Asignación Universal Por Hijo. Nosotros insistimos: los llamamos, pero ya algunos no nos atienden. Vamos a las casas, los invitamos. Pero ya no nos está dando resultado eso, por lo menos este año".

Las maestras de grado son supervisadas. Refiere la Directora: "gente del Programa Integral por la Inclusión Educativa monitorea los aprendizajes de los cbicos y supervisa si los contenidos se están aplicando correctamente. Habia falencias en la enseñanza, errores que habia que modificar; no sólo en Prácticas

\footnotetext{
${ }^{24}$ El Ministerio de Educación diseña e implementa el Programa Integral para la Igualdad Educativa desde el año 2004 para dar respuesta a las problemáticas educativas relacionadas con la fragmentación social y la desigualdad de oportunidades educativas.
} 
del Lenguaje, sino también en Matemáticas. A veces se centran en una cosa y se descuida la lecto-escritura, que es una enseñanza global".

En la oportunidad que tuve de entrevistar a la maestra de $1^{\text {er }}$ año en situación áulica, observé que dos niños estaban con sus respectivos acompañantes terapéuticos ${ }^{25}$. La maestra refirió la presencia de un niño que era la tercera vez que repetía dicho grado. "No ha progresado nunca, no sé cuál es su problema. El padre, por recomendación nuestra, lo llevó a una escuela especial, pero ahora está de vuelta acá. Ese nene... no sé cuál fue el motivo, no sé cómo se manejó la cuestión...”.

\section{Escuela "E".}

No hay obstáculos para la lectura: cuando la escuela piensa, no en términos de problemas, sino de desafíos.

Está tan lejos de Berisso el establecimiento que parece que no pertenece a dicha ciudad. Y está tan lejos que la frecuencia del micro, a excepción de quienes disponen de un medio de trasporte particular, sólo nos brinda una opción para llegar a horario. A las claras: si no estás en la parada de la Plaza San Martín a las 6.45 a.m., que llega a la puerta del establecimiento a las 8.00 a.m., sólo te queda la opción de un micro de media distancia, que hace el camino a Magdalena, pero ese es otro precio.

Sin embargo, arribar a esta escuela remunera con creces la distancia recorrida e, incluso, el tener que iniciar el día tempranamente: la escena que inaugura el comienzo del día allí es un desayuno compartido entre niñas y niños del nivel inicial y primario y sus respectivos maestros. Estos últimos colaboran con los auxiliares en las tareas iniciales: servir el mate cocido, ayudar a quienes quieren servirse pan y mermelada. Un niño de la última sala de jardín se acercó a su maestra, quien se tuvo que inclinar para escuchar lo que el niño le solicitaba: "Seño, llegó Lucía y no tiene silla", mientras señalaba a su compañera que estaba parada en la puerta de entrada del Salón de Usos Múltiples.

"Acá no necesitás gritar", me dijo una maestra. Y, luego de entrevistas y conversaciones espontáneas, la mayoría de las docentes estaba feliz de poder trabajar allí. Expresiones del tipo “... una vez, me desplazaron, porque acá empecé como suplente y después pude volver a tomar acá un cargo como titular... para mi trabajar acá es una bendición", "Yo acá vengo feliz a trabajar, tengo bumor. Si no tenés humor, ponete una verdulería. Porque no podés trabajar en una escuela si no tenés una sonrisa. En la otra escuela donde trabajo también soy así, pero acá, en esta escuela... yo aprendí mucho, de mis compañeros de la Directora, que quiere que siempre te estés formando".

25 Los acompañantes terapéuticos son agentes, contratados por la Obra Social de los referentes familiares, para acompañar a sus hijas e hijos con necesidades educativas especiales tanto en el propio hogar como en las aulas. 
"Acá es inevitable que un chico no salga alfabetizado de primero", refiere la docente a cargo de uno de los primeros años. Y avanza, pensando sola en su respuesta: "Está bien, son diez chicos, pero en la otra escuela son más y el trabajo es el mismo. Lo que digo es que percibo que con diez chicos, acompañamiento de la familia, tenés acompañamiento del directivo, trabajás con colegas en determinados proyectos: no tenés lugar para un "no se alfabetizó" (...). Acá también hay docentes que se quejan: que el chico esto, que la familia lo otro. Y yo les digo: no te quejes, hacé tu función que es darle herramientas al pibe para que pueda elegir (...). Porque muchos se quejan del pibe y de la familia. ¿Y el docente?, que también venimos cansados, que venimos con problemas de afuera. Hagamos un mea culpa. Esto es una escuela rural y muchos vienen con la imagen de que esto es tomar mate, no más. Y vos al pibe tenés que darle opciones, mostrarle el abanico. Preguntarse: ¿qué es lo que quiere el pibe para su vida?".

Tuve la oportunidad de observar los recreos. Puntos de lectura en el patio, ya que no cuentan con espacio de biblioteca escolar. Sólo un almacén de libros donde la bibliotecaria desarrolla el inventariado y guarda materiales didácticos. En detrimento de la tendencia a pensar que los avances tecnológicos reducen el interés por las prácticas lectoras, la bibliotecaria escolar consiguió mil textos literarios digitalizados e informa a través de carteles que los chicos pueden pasar con sus dispositivos de almacenamiento y leer desde la computadora. "El trabajo con el secundario es ad-honorem; sólo me pagan por trabajar para primaria, pero quiero tener organizados todos los materiales, les estoy enseñando a ellos cómo inventariar", comenta la responsable de la biblioteca.

En los recreos, como se expresó antes, se establecen puntos de lectura con estantes móviles repletos de libros. Niñas y niños se disponen a leer interesadamente en diferentes lugares, sentados en el suelo, ya que la biblioteca no cuenta con espacio para una sala de lectura. Niñas y niños del nivel primario sentados sobre almohadones eligiendo libros, mostrándose las ilustraciones y también leyendo colectivamente en voz alta e invitando a las docentes a escuchar la historia. Recuerdo que un niño de $1^{\mathrm{er}}$ año miraba solo un libro-álbum, lentamente, reparaba en una ilustración, después de haberse detenido en el texto escrito y se reía. También un niño del segundo ciclo se acercó para preguntarme quién era, qué hacía y al contarle que estaba interesado en saber cómo las maestras y los chicos leían en la escuela, me comenta "Yo leo en mi casa, antes de dormir a la noche. Mi hermana también. Estoy leyendo Querido bijo: estás despedido",26.

En otra oportunidad la bibliotecaria me cuenta: "También organizo la Feria del Libro Artesanal en la escuela, estoy detrás de todo eso. Dentro de la biblioteca funciona un espacio cultural que se llama '1920', que es el que se encarga de traer números artísticos y permite la entrada de la Escuela de

\footnotetext{
${ }^{26}$ Sierra i Fabra, Jordi (2002). Querido hijo: estás despedido. Madrid, Editorial Alfaguara.
} 
Orquesta para que den clases de violín. También tenemos un rincón de Berisso donde tratamos de traer todo lo relacionado con la localidad, para preservar la identidad, porque estamos tan alejados del centro que nos confunden con La Plata o Magdalena (....). La Feria del Libro no sólo se trata de libros: incluye arte plástica, música. En invierno, imaginate, acá hay mucho viento, así que están todos en el pasillo de la escuela leyendo y están muy acostumbrados. Me encargo de que tengan, además de los títulos ordenados, una caja separada para que puedan revolver durante los recreos si ninguno de los libros exbibidos les gustó. Los pongo separados así pueden revolver".

Un dato relevante en torno a las prácticas que amplían el acerbo bibliográfico: como no disponen de dinero de cooperadora, además de los que reciben de los diferentes organismos estatales, algunos ex alumnos se acercan en autos a dejar libros que van juntando y si hay algún proyecto que requiere material literario específico se convoca a los padres para que elaboren comidas y los docentes se encargan de vender los productos en una Feria del Plato.

En torno a la relación con los referentes familiares, los agentes escolares afirman: "Ellos están en todo momento. Igual yo les digo que si hay que hablar algo me voy a comunicar, por el cuaderno o por teléfono. Porque acá cuesta mucho llegar y los padres son precarios, la mayoría changarines y las mujeres trabajan como empleadas domésticas. Si yo los cito, no es como nosotros que podemos pedir el día o licencia. Ellos, si no van a trabajar, no cobran (...). La población que recibimos es mayoritariamente paraguaya y se desempeña en la construcción, por eso si faltan y no recuperan el día, no cobran. Yo te puedo asegurar que si no vienen a los actos es porque no pueden: por una cuestión de tiempo y laboral. Las mujeres también tienen que llevar a los hijos al hospital, levantarse temprano para sacar el turno, etcétera. Sí hacemos hincapié en que los padres concurran al acto de inicio de clases y al finalizar el ciclo lectivo, porque es importante para los chicos".

Con los chicos suele trabajarse el guaraní, a partir de leyendas que actúan como disparadoras para inmiscuirse en la lengua, y fomentar la presencia de la misma en el contexto institucional, ya que muchos niños que asisten viven en el asentamiento de la comunidad paraguaya.

\section{La escuela "F".}

Cuando el "otro es no lector": las prácticas de lectura posibles a partir del prejuicio y la marginación.

"No bay problema que vengas a bacer la investigación acá... solamente que no sé si te va a servir, porque acá los chicos no leen..., pero sí, vení. Nos interesa que alguien nos diga qué pasa con la lectura", me comenta la Directora del establecimiento en la primera comunicación telefónica. 
En la puerta de entrada a la biblioteca hay un cartel que informa a los usuarios que el préstamo de libros se realiza los días martes y jueves: en el primer recreo pueden asistir solamente los alumnos de $1^{\text {er }}$ y $2^{\text {do }}$ grado; en el segundo, los de $3^{\text {er }}$ y $4^{\text {to }}$ año y, en el recreo final, los alumnos de $5^{\text {to }}$ y $6^{\text {to }}$. Por fuera de esos días y horarios, no se puede acceder al préstamo domiciliario de libros.

Dos niñas se paran frente a la puerta de la biblioteca y una le comenta a la otra: "¿Qué día es hoy? (...). iAh, viernes! Hoy no", y siguen caminando hacia el patio. "Se arma mucho lio si ponemos el préstamo todos los días", me comenta la auxiliar. "Acá los chicos te cansan", refiere la bibliotecaria escolar que se desempeña como maestra de $2^{\text {do }}$ año en el turno tarde del mismo establecimiento.

En la biblioteca escolar hay un espacio amplio. Al costado del escritorio donde se ubica la bibliotecaria escolar o la auxiliar, en sus respectivos turnos, hay unas cajas con etiquetas correspondientes a cada año: son los libros que los alumnos pueden solicitar en calidad de préstamos externos. En su mayoría, los libros son textos escolares, aunque hay algunos libros de literatura exclusivamente. Los libros suelen tener las tapas rotas y faltan en su interior páginas. Las novelas y libros de cuentos se ubican en los estantes del mueble de biblioteca, pero no se ofrecen en calidad de préstamo domiciliario. Los libros enviados por el Ministerio de Cultura y Educación, tanto provincial como nacional, de elevada calidad estética y editorial, se ubican en un mueble bajo llave. Las niñas y los niños desconocen la existencia de dichos materiales.

En el turno mañana, se desarrollan situaciones de alta conflictividad: entre docentes y niños y entre niños, sin que medie entre las peleas de estos últimos la intervención adulta. Si en el aula los niños no se organizan para el trabajo, es común que la docente los deje solos, esperando que dejen de gritar. Pocas veces se solicita ayuda a otros compañeros para modificar la situación. Generalmente se escucha decir: "Están terribles". De hecho, la mayoría de las maestras de grado del turno mañana tratan de acceder a otros cargos, "más tranquilos", refieren; ya sea en secretaría, como preceptoras o bien, en la biblioteca escolar, total, “... se mantiene la puerta cerrada, para que no entren los cbicos", comenta la bibliotecaria escolar. Durante la estadía en el establecimiento algunas docentes refirieron no soportar más el trabajo áulico, ni a los chicos.

En el Proyecto de Lectura Institucional el nombre de la bibliotecaria escolar se encuentra tachado con lápiz. Allí se propone la lectura de dos obras seleccionadas por las maestras de grado, para leer en dos cuatrimestres. Una vez a la semana, cada grado concurre a la biblioteca escolar para ampliar información sobre Ciencias Naturales y Ciencias Sociales, 
pero el espacio nunca está acondicionado: los niños deben ir a buscar mesas y sillas porque son insuficientes, adecuarlas al espacio existente, buscar los libros que necesitan. Todo sin el acompañamiento de la bibliotecaria o de la maestra. "La formación del usuario no le interesa a la bibliotecaria", me explica la Directora.

Las niñas y los niños corren y gritan durante el recreo. Las peleas entre ellos suelen originarse por burlas en torno a la procedencia de sus grupos familiares, de los barios pobres de los cuales provienen y, también, porque muchos de ellos, incluso cursando años avanzados, todavía no saben leer. En efecto, el primer y segundo ciclo hay niñas y niños que aún no se han alfabetizado. "Decodifican letra, palabra y frase", comunica la maestra de $5^{\text {to }}$ año, pero no respetan puntuaciones ni entonaciones.

En las situaciones de lectura libre que realizan todos los grados durante la última hora de clases del día viernes se mantiene en las aulas la disposición tradicional: la maestra en su escritorio y los alumnos de frente al pizarrón. Además, las niñas y los niños comparan: "Los libros que traés vos acá no son como los que tengo en casa (...). Son lindos". O bien, "Yo tengo libros de escuela, no de estos". Una niña comenta que "libros hay en la casa de D., donde también hay biblioteca y van maestras que ayudan a los chicos. Abi tomo la merienda y con otros chicos armamos una comparsa. En el comedor también almuer:̧o".

A partir de $4^{\text {to }}$ año se registraron niños que no tenían carpeta de trabajo. "Acá hay que darles todo, vienen sin nada", expresa una maestra de grado. Es frecuente también que, al final del día, ya organizados en fila para el saludo a la bandera, la Directora les anuncie la importancia de "... la auto-evaluación. Para que nos cuenten por qué no aprenden si acá se les da todo para que aprendan". O bien: "Por qué no aprendí algunas cosas hasta el momento si cuento con todos los recursos materiales para aprender".

En la biblioteca escolar había juegos de mesa para que los niños retiren durante los recreos o en horas libres. Al poco tiempo, fueron desplazados a la Dirección. Cuando un grupo de niños ingresa a la biblioteca donde estaban las dos docentes a cargo -la bibliotecaria escolar y la auxiliar-, ambas le informan al grupo que ya no están ahí. Tampoco les comunican dónde fueron re-ubicados. Los niños se retiran del espacio y la auxiliar le comenta a su compañera: "Qué malas que somos!

Así y todo, para el Día del Idioma, la bibliotecaria escolar elaboró un cartel basándose en un Proverbio hindú que dicta: "Un libro abierto es un cerebro que habla; cerrado, un amigo que espera; olvidado, un alma que perdona; destruido, un corazón que llora”. Evidencia de la distancia entre la promoción de la lectura y la formación de lectores. Proverbio que, en las 
palabras de Bleichmar (ibídem), se convierte en un eufemismo que esconde, borra, la calidad de la acción.

Todos los días se ve interrumpida una asignatura por el ingreso del personal no docente con la vianda que se les ofrece en ambos turnos, la cual insume toda la hora de clase. "Los padres demandan que la carpeta se llene, que se hagan muchas actividades abi; pero el trabajo en clases también es oral y el registro no es escrito". Pero "No importa que no trabajen; importa que no molesten", amplía en otra oportunidad la misma docente.

Los niños suelen distraerse del trabajo en el aula, realizando sus actividades preferidas: algunos dibujan, otros hacen Origami e, incluso, munidos de compás, escuadra y lapicera, hay quienes ensayan complejas mandalas. Mientras tanto, la maestra revisa su celular, chequea las inasistencias. También sucede que los niños se encuentran, luego del dictado de una consigna, sin apoyo de la docente para realizar la actividad. Son pocos los que se acercan refiriendo alguna inquietud ante la tarea asignada.

Durante los recreos, armamos con chicos de todos los años un espacio de lectura. Allí, de manera fluctuante, se acercaban a compartir la lectura de algún libro, o sólo a mirarlos. Algunos de ellos me solicitaban que se los leyera, porque todavía no sabían hacerlo por sus propios medios. Solía organizar algunos grupos con edades mixtas, para que los más grandes les leyeran a los más pequeños. Incluso la lectura compartida resolvía el conflicto cuando dos niñas se peleaban por el único ejemplar. En eso la bibliotecaria escolar tenía razón: “... hacen mucho lio, se pelean y tironean los libros, hasta que terminan rompiéndolos. También los pierden o no los devuelven porque se los queda un bermano".

Respecto a lo anterior, con la intervención de un adulto, los niños se organizaban para la lectura. Ello también favorecía que los niños comenzaran a plantear intereses particulares sobre temáticas (no demandaban en términos de géneros o autores). No me extrañó que la bibliotecaria haya referido que los libros que solicitan los alumnos suelen quedárselo sus hermanos. Cuando solía mostrarles libros durante los recreos, muchos de los niños del segundo ciclo señalaban aquellos libros pensando en sus hermanos más pequeños y no en sus gustos propios. "Este libro le gustaría a mi hermanito. ¿Se lo puedo llevar?", me preguntó un alumno de $4^{\text {to }}$ año.

\section{Sumario del capítulo.}


A partir de la exposición de las características de los escenarios escolares se pretendió describir, por un lado, las relaciones entre los distintos miembros de la comunidad educativa (directivos, docentes, bibliotecarias, estudiantes, padres, entre otros) y, por otro lado, identificar modos de constitución de las docentes como mediadoras entre la niñez y los libros, la lectura y la literatura. Ello exigió enunciar los dispositivos de lectura propuestos por las docentes como condición para conocer el modo de acceso de niñas y niños a los libros, los tiempos para leer y los ambientes creados para la lectura.

Observando el clima institucional, a partir de las relaciones entre docentes y su disposición al trabajo y de la identificación de los alcances y límites de sus propuestas para leer literatura, se puede establecer una primera conclusión: no hay una correlación mecánica entre posición de clase y lectura, pues la relación de niñas y niños está configurada por la función de las mediadoras, las oportunidades para acceder a los libros, los dispositivos y tiempos para leer, entre otros aspectos.

Por ejemplo, en escuelas de similar condición socioeconómica, tales como los establecimientos C, D, E y F, se identificaron situaciones muy diferentes en torno a la lectura: en el caso de las escuelas $\mathrm{D}$ y F, el imaginario de las docentes respecto de la población que asiste condiciona el acceso de niñas y niños a los libros y la literatura. En las instituciones $\mathrm{C}$ y E, el desempeño de las docentes como mediadores favorece la vinculación de la niñez con el lenguaje poético, superando aquello que suele conceptualizarse como "obstáculos de clase".

En los establecimientos coordinados por Directivos que basan su autoridad en el orden y la disciplina, tales como en las escuelas $\mathrm{B}$ y F, los proyectos de lectura tienen un escaso impacto en término de favorecer la apropiación de hábitos lectores. En establecimientos tales como A, C y E, con una impronta de los Directivos que flexibiliza "la lógica escolar", se promueve en niñas y niños un uso autónomo y creativo de los bienes culturales. A su vez, en estos establecimientos se propone un uso frecuente del espacio de biblioteca escolar, como espacio estratégico para la formación de usuarios y lectores, aún cuando existen condicionamientos para el usufructo de este escenario.

Otro diacrítico que constituye diferencias en cuanto a las posibilidades para la lectura lo configuran las relaciones entre compañeras. Es así que en el caso de la escuela C y E, la posibilidad de trabajo mancomunado a través de parejas pedagógicas o de las interacciones cotidianas y espontáneas, contribuye a la superación de obstáculos en el quehacer docente. En cambio, en instituciones tales como B, D y F, el repliegue de las docentes ante sus dificultades para ejercer la profesión aumenta el sentimiento de soledad y la frustración en el cotidiano de sus funciones. 
Por último, el uso del tiempo es un factor que condiciona la experiencia lectora de niñas y niños. En los establecimientos A, C y E se apuesta, generalmente, a un uso del tiempo necesario para la lectura. Esto significa promover un tiempo que, interpelando la rigidez de las horas por asignatura, sea experimentado como tiempo para el disfrute, la creatividad y la suspensión del cotidiano. En las escuelas B, D y F, con frecuencia, el tiempo de lectura reproduce el tiempo propiamente escolar en sentido estricto: se lee para introducir contenidos curriculares, se lee para responder a las directrices de un proyecto lector al que nunca se adhirió con voluntad.

Asimismo, la postura ético-política de las docentes, y no la edad y la generación de estas profesionales, constituye un factor relevante en la definición de propuestas viables para que niñas y niños se apropien de la lectura literaria. En este sentido, muchas docentes formadas desde un paradigma tradicional, basado en una concepción instrumental de la lectura, a partir del apoyo de directivos y colegas, son permeables a nuevas estrategias alfabetizadoras. 


\section{Capítulo IV. Los agentes escolares: representaciones y prácticas.}

La fórmula bourdieana dicta que "lo real es relacional". Pero la ironía lacaniana quiebra la frontera de lo decible, anunciando: "lo real es imposible". Asumir la ironía de la premisa lacaniana es aceptar que el abordaje de la realidad no es sino a condición de aquello que se constituye como fragmento, lo que no significa negar la totalidad: sino resistirse intelectualmente a que el pensamiento sobre la realidad devenga totalitario.

Espero con esta introducción poder sortear la definición conceptual de categorías tales como "representaciones" y "prácticas". A lo sumo, bastará que refiera que el presente capítulo se elabora a partir de los discursos de los sujetos entrevistados y de los registros de sus interacciones cotidianas. Así, "representaciones” y "prácticas" interesan más como emergentes de un contexto particular, como "hechos totales" no susceptibles de agotarse en una narrativa. Dicha narrativa, aunque siempre relativa, es condición de posibilidad para participar en la producción de conocimiento, y ello porque exige posicionarse, asumir un lugar de enunciación, que sintetiza herramientas teórico-metodológicas.

En efecto, me interesa señalar que "representaciones" y "prácticas", a los fines del presente trabajo, existen sólo a condición de aquello que Bahloul (2002: 23) define como "escenarios de lectura". Apropiarnos de esta conceptualización nos permitirá referirnos al conjunto de condiciones producto de la historia familiar, socio-profesional y educativa de los lectores (Bahloul; ibídem) que participan en una situación escolar de acercamiento a la literatura y que se traducen en prácticas significativas.

Es así que en este capítulo se expone, por un lado, la relación que las docentes establecen con los libros, mediatizadas por las directrices del diseño curricular y por su propia biografía lectora. Por otro lado, a partir del vínculo docente con las niñas y niños, se identifican y analizan las representaciones de infancia y las ideas que estos adultos portan respecto de los sujetos a su cargo.

Siguiendo a Bombini (ibídem), en el estilo de escritura etnográfica se parte de reconstruir las escenas de lectura, pues estas son consideradas como el punto de partida para la construcción de conocimiento sobre los modos de leer de distintos grupos de lectores. Por ello, a partir de esta categoría es posible comprender que todo proceso de lectura comprende aquello que los lectores deben hacer para que la "lectura" sea posible (Chambers; 2007: 14), 
puesto que para aprender a leer hay que leer: el proceso de lectura comprende una serie de actividades de las cuales extraer las palabras de las páginas es sólo una (Chambers; íbidem: 18).

La complejidad para narrar los procesos de lectura que se escenifican en contextos escolares, requiere situar a los alumnos como lectores y a los docentes como mediadores, pero también como lectores. Al respecto, Lerner (citada por Moreno Arteaga; ibídem) sugiere que la formación del docente se estructura en una línea temporal extensa, la cual apunta a la integración de nuevos saberes en su forma de concebir el campo educativo, tanto como aquellas lecturas que le permitan confrontar sus puntos de vista no sólo en el espacio de la clase de formación sino en su espacio privado.

Describir y analizar las posiciones particulares del docente como mediador nos sitúa en un complejo entramado. Este entramado conjuga tanto la memoria afectiva y cognitiva de todas las marcas que constituyeron a dichos agentes como lectores (Leiza de Almada y Duarte; ibídem), como el movimiento dialéctico que va de lo privado e íntimo de su vida personal a lo público y socialmente compartido en la escuela y en la comunidad en la que se inserta (Delgado y otros; ibidem).

Al respecto, Bourdieu (ibidem: 91) afirma que las prácticas no pueden ser explicadas sino a condición de vincular las condiciones sociales en las que se ha constituido el habitus que las ha engendrado con las condiciones sociales en las que este opera. Es decir, a condición de realizar mediante el trabajo científico la puesta en relación de esos dos estados del mundo social que el habitus efectúa, ocultándolo, en y por la práctica. Lo cual nos recuerda, siguiendo a Gutiérrez Valencia (2009), que la accesibilidad a la lectura literaria privilegia la producción de datos originales y, por lo tanto, necesariamente limitados, como estudios de casos y ejemplificaciones, que tienen carácter ilustrativo.

\section{Docentes y libros: prescripciones curriculares y trayectorias} lectoras.

A los fines de analizar la relación de las docentes con los libros, la lectura y la literatura, se especificaron dos líneas de indagación para capturar la complejidad de las representaciones y prácticas asidas a la apropiación del lenguaje poético. Es así que, a continuación, se exponen dichos lineamientos, los cuales posibilitaron comprender el quehacer docente en el marco de una estructura compleja y articulando, por un lado, cómo se posicionan ante las prescripciones curriculares y, por otro lado, indagando en su memoria afectiva a partir de fragmentos que esbozan sus biografías lectoras. 


\section{La relación con las prescripciones curriculares.}

El diseño curricular vigente explicita, a las claras, las transformaciones operadas por una revisión del paradigma lingüístico, como estructurante de la tradicional asignatura Lengua y Literatura: revisión que incorpora la dimensión social, centrando el interés por partir de las prácticas del lenguaje que efectivamente realizan las niñas y los niños. Las transformaciones en torno al paradigma señalado son identificadas por los agentes de las siguientes maneras:

("A"-MG-TT-4 (o) $^{27}$ "se notan (las transformaciones curriculares) en la oralidad y en la escritura, que es lo que fundamenta las Prácticas del Lenguaje (...). Ahora los chicos mezclan y a raíz de esa mezcla, diciéndolo de entrecasa, sacan palabras, sacan el abecedario, sacan todo”.

("A"-MG-TM-1"ero "Que los nenes se puedan expresar. El hecho de hablar, los cuentos. Y que eso genere otras cuestiones: surgen debates, situaciones inesperadas y si me equivoco, no importa: hablemos. El hecho de no tener miedo al error, de tener que decir lo correcto. ;Algunos te discuten! Ese cambio me da gracia, esa es la parte que me interesa. Y asi vas viendo lo que tienen los niños, lo que traen de las casas, esas cabezas que vuelan (....). El cambio en la oralidad del diseño curricular combate el mutismo”.

("A"-MG ${ }^{2}-\mathrm{TM}-1^{\text {ero }}$ ) "Me parece fantástica la propuesta y tampoco es tan difícil de abordar. Implica voluntad y compromiso. Y tiempo. Entiendo que con dos cargos puede resultar complicado".

En estos tres fragmentos prima una evaluación positiva de las modificaciones curriculares. Asimismo, se establece en el último discurso una imperiosa necesidad de dedicarle tiempo a la lectura que, en términos de condiciones laborales, es complicado: la rutina y desgaste laboral va en detrimento de la posibilidad de sostener prácticas creativas que favorezcan el vínculo de la niñez con los libros y la literatura. En este sentido, puede explicitarse que, si bien las condiciones nunca están dadas, existen complicaciones reales para implementar las directrices curriculares. Es así que la falta de herramientas que permiten motorizar en el aula la propuesta del diseño pueda concebirse como un elemento de frustración y desmotivación.

\footnotetext{
${ }^{27}$ Para identificar el discurso de los actores y su pertenencia institucional se efectúan las siguientes abreviaturas. La escuela a la que pertenece es designada por una letra entre comillas (tal como se efectuó al momento de presentar cada institución educativa), el cargo docente (MG: maestra de grado; BE: bibliotecaria escolar) y el turno en el que se desempeña (TM: turno mañana; TT: turno tarde). También se explicita el año que la maestra tiene a su cargo.
} 
El paradigma didáctico que configura el actual currículum está centrado en el alumno, en sus estrategias cognitivas y lingüísticas, y en sus preferencias estético-culturales (Puntanto; 2011). A diferencia de las valoraciones positivas anteriormente citadas, algunas docentes suelen referir que en el diseño curricular vigente, todos los aprendizajes son "descontextualizados", y ello porque interpelan la tradicional forma de enseñar lengua. Veamos algunos fragmentos de entrevista que ilustran, diferencialmente, lo referido:

("A"-MG-TM-1" ero "Antes vos dabas "El Sustantivo", y lo que hacias era dar una definición, y ahora hay que encararlo desde otro lugar. Con el análisis sintáctico, imaginate: jse agarran la cabeza las maestras!”.

("F"-MG-TM-4") "Con las Prácticas del Lenguaje, hay cosas que ya eran sabidas, como por ejemplo, desmenuzar sustantivos de un texto. Hay una mezcla entre lo tradicional y lo..." (no completa la frase).

("D”-MG-TT-1 ero "... yo no creo que los chicos de primero al ver una palabra sepan lo que dice (...). Pero en el aprendizaje de la lectura, me gustaba más cómo lo hacía antes que era más... remarcar bien las letras. A través de la palabra generadora, pero mezclándolo con lo actual. No ese ma- me-mi -mo -mu. No, no. eso tampoco. Es muy estructurado. Pero sí que uno pueda decir bien la fonética.

Los docentes que proponen actividades tales como extraer de un texto, incluso literario, sustantivos y verbos, o la noción del lenguaje enfáticamente vinculada con aspectos fónicos, explicita la pervivencia de discursos situados en el paradigma lingüístico. Desde este posicionamiento, primero se estudiaría la lengua para, después, utilizarla.

Sin embargo, las formas tradicionales de enseñar lengua y literatura que se centran en contenidos que los alumnos deben adquirir -con independencia de la situación comunicativa y de la intención-, obturan el reconocimiento de herramientas que favorecerían las prácticas del lenguaje en las interacciones cotidianas: hablar, escribir, escuchar y leer.

Para ilustrar lo mencionado, recurrimos al siguiente extracto:

(“E”-Directora) “... el trabajo de los docentes en Prácticas del Lenguaje es bárbaro. El otro día, uno de los chicos de $3^{\text {ero }}$ fue puesto en penitencia por sus padres, porque se portó mal. Le probibieron hacer con sus compañeros el viaje a un museo en Buenos Aires. Tres de sus compañeros escribieron 
una carta a los papás para que lo dejaran ir (...). Lo más interesante de todo, es que surgió de los mismos chicos. El papá vino a mostrarme la carta, riéndose”.

En la situación anterior se evidencia una apropiación de las prescripciones curriculares que favorece espacios donde las niñas y los niños aprehendan, no a usar, sino a ejercer el lenguaje. En este sentido, la construcción de los sujetos como usuarios de la cultura escrita se amplía, en tanto se implica con dimensiones éticas y estéticas. A su vez, en la situación señalada, los niños establecen una correlación entre medios y fines, en pos de bregar por un objetivo preciso: modificar la situación en la que se encuentra uno de sus compañeros pudiendo, a través de la palabra, tener presencia pública.

Asimismo, la pervivencia de la tradición que instala la enseñanza de la lengua y la literatura no sólo opera a través de la repetición sin sentido o de la clausura de todo debate en torno a los procesos educativos. En ocasiones, la tradición suele apropiarse de las transformaciones como si estas fueran modas, lo cual se reduce a aprender el lenguaje acorde, sin que ello signifique conocer los fundamentos o investigaciones que avalan científicamente la propuesta, ni modificar el proceso de enseñanza-aprendizaje. Se propone un ejemplo para favorecer la comprensión de lo explicitado:

("F"-diálogo entre Maestras de Grado y Bibliotecaria Escolar-TM):

- "Yo ya no entiendo cómo es el tema de la lectura" $\left(5^{\text {to }}\right)$.

- "Si, tal cual. Tenemos la "lectura por placer", la "lectura que nos obligaron acá" y la "lectura de los libritos que envió (la Dirección de Cultura y Educación de la) provincia" $\left(4^{\text {to }}\right)$.

- "Para mí, lo de la "lectura por placer" es lo que yo les doy todos los viernes en la última bora, que saco los libros de la biblioteca áulica y los ubico en una mesa para que recorran y elijan los chicos" $\left(2^{\mathrm{do}}\right)$.

- "A mí también se me desordenó la clase de Lengua con tanta lectura" (Bibliotecaria escolar).

- "Ya no es más Lengua, sino Prácticas del Lenguaje. Grabátelo. Y buscame algunas versiones de Caperucita Roja, asi las ojeo por encima para leérselas" $\left(2^{\mathrm{do}}\right)$.

En las interacciones de estas docentes no se presta atención al vacío de propósitos que estructura la discusión en torno a la organización de las situaciones de lectura literaria. Así, las 
propuestas de lectura se reducen a cómo habría, de antemano, que leer determinado libro "leer por placer"-, o bien, a leer porque es una propuesta de lectura motorizada por instancias superiores del sistema, sin que ello implique una lectura de los intereses, políticas y proyectos de las instituciones particulares. "Leer por el placer de leer", la "lectura de los libritos de provincia", la "lectura que nos obligaron acá", en referencia al Proyecto de Lectura Institucional; todas ellas, formas de lectura que invisibilizan al sujeto destinatario y a la productividad de la práctica.

Lo anteriormente expuesto se vincula directamente con las consecuencias derivadas de una re-adaptación profesional, la cual se instala como proceso de transformación de los fines de la educación, pero manteniendo los mismos medios con los que se cuenta (Chartier; 2004: 38). Un fragmento de entrevista remite a este señalamiento:

(“A"-MG-TM-1" ero "Tendrian que perfeccionarnos más. Que nos den más información. Porque vos querés hacerlo bien, pero necesitás herramientas (...).

El fragmento anterior se conecta con las evaluaciones positivas que anteriormente se señalaron en torno al diseño curricular insistiendo, también, en la necesidad de capacitación ya que se señalan condiciones no idóneas para implementar la propuesta.

A continuación, atendemos a una propuesta de trabajo narrada por una docente:

(“A"-MG-TM-1" ero ) "Fichamos los libros de la biblioteca áulica y empezaron a llevárselos. Es una forma distinta de acercarse al material. Lleva tiempo: uno puede estar tres cuartos de mañana para que ellos fichen. Pero es importante que hagan ese trabajo, para que se den cuenta de que hay gente trabajando en ese libro".

Es interesante la noción de "tiempo" que se explicita en el discurso de la docente: "tres cuartos de mañana” es el tiempo necesario para realizar la actividad propuesta. La medida de tiempo empleada por la docente, trastoca el tiempo cosificado en asignaturas y horas reloj. "Tres cuartos de mañana" es una expresión que insiste en la importancia de abandonar la tiranía dominante del tiempo necesario de trabajo a favor de la adopción consciente y el uso creativo del tiempo disponible, en tanto principio orientador de la reproducción social (Mészáros; ibidem: 92).

Además, reflexionar en torno a las intervenciones docentes desde el tiempo disponible promueve claridad en torno a los propósitos de la acción: fichar para reconocer que hay gente 
detrás del libro, escritores, lugares de edición. Y ello, solapadamente, a través del ritmo de trabajo, inscribe en los alumnos múltiples referencias que se estructurarán como recursos para dichos niños en tanto lectores.

Así, la presión del tiempo o su empleo de forma creativa, marca de forma decisiva el tratamiento de los contenidos. El conocimiento se va distribuyendo a través del tiempo y esta distribución hace que adquiera características particulares, diferentes a las del objeto original (Lerner; 1993).

Agrega la misma docente:

"... lo más importante fue que en la casa siguieron trabajando, con los libros que tenían en sus casas. Que se interesaron. Me trajeron para ver lo que habian fichado en sus casas. Creo que eso ayudó a que conectaran con los materiales que tienen en sus hogares".

También es posible especificar las transformaciones que el diseño curricular vigente significa para las docentes que desempeñan cargos como bibliotecarias escolares:

("C"-BE) "A partir del diseño, apostamos al armado de parejas pedagógicas, una propuesta de trabajo avalada por la Dirección de Cultura y Educación. Eso nos permite a las bibliotecarias escolares, ser un recurso para las maestras porque el trabajo más arduo está en el aula. El trabajo en parejas pedagógicas te permite contar con un compañero que te puede ayudar; es alguien a quien le podés delegar porque sabés que también está trabajando con los chicos y que los conoce (...). Para mí fue como un premio poder ir al aula, participar más de la vida escolar (...), no tener que estar solamente en el depósito de libros (...). Es importante que a todos nos interese el trabajo del compañero".

Constituirse como grupo de trabajo, a partir de la normativa vigente y sobre la apoyatura de otros documentos afines para imaginar las intervenciones docentes, ofrece otros elementos para pensar la identidad como bibliotecaria escolar. Así, las funciones de dicho agente no se reducen al almacenamiento de libros, a la elaboración del inventario -tarea necesaria puesto que favorece un orden-, sino que se amplía a acciones de difusión del material disponible, desde una perspectiva atenta a la formación del usuario. Retomamos un fragmento de la bibliotecaria anteriormente citada: 
"Mi tarea es que el chico sea autónomo en el espacio de biblioteca, con mi acompañamiento (...). Que sepan que la biblioteca es un espacio abierto es lo primordial. Y si no vienen, pido permiso y voy al grado (...). En cuanto a la biblioteca, sé que prestar libros implica perderlos, pero por suerte tenemos pocas pérdidas. Pero si hay material que se pierde, pero es material que fue leído por el chico, no importa: se vuelve a comprar (...). También en la biblioteca hay que acostumbrarse al desorden, por ejemplo, cuando trasladamos para una Maratón de Lectura todos los libros de la biblioteca al Salón de Usos Múltiples. Me parece que la gran resistencia al diseño curricular es porque somos los docentes los que tenemos que aprender. Por eso, para fin de año, propuse un proyecto a nivel docente para que cada uno se lleve, al menos, dos libros para comentarlos luego de las vacaciones (...). Algo así como formación de usuarios... ipero para docentes!"

Este fragmento expone transformaciones profundas en los ámbitos (y hábitos) escolares: hay libros que se pierden, hay un desorden que se produce con la presencia de cuerpos insumisos que se acercan a los libros, y eso no es percibido como negativo. Hay niñas y niños demandando libros y socializando sus lecturas: y ello es lo que se celebra.

Otras docentes, insertas en la biblioteca escolar, se proponen incidir en la formación de lectores presentándose ellas como lectoras en el cotidiano escolar:

("E"-BE) "La promoción de la lectura la hacemos los docentes: leyendo. Que nos vean leer es importante. Cuando tengo un tiempo libre me pongo a leer, que pasen y que me vean leer (...). Por eso también en las fiestas o reuniones de padres, busco libros que les sean interesantes para que ellos también lean, y para que sus bijos también empiecen a tenerlos en cuenta como referentes".

En la Escuela "E", se observó, previo a un acto escolar, cómo los padres que asistían al evento se reunían en la mesa con libros, exclusivamente preparada para ellos: historietas, libros sobre Berisso, incluso Atlas. Un padre conversaba con la Directora sobre un libro que esta última le había recomendado. Una mamá comparte con su hija adolescente historietas de $\mathrm{Mafalda}^{28}$.

Posicionamientos y prácticas diferentes a los anteriormente descriptos, se corresponden con un desconocimiento en torno a las prescripciones curriculares:

\footnotetext{
${ }^{28}$ Nota de campo, Escuela E, Berisso, Octubre de 2011.
} 
("B"-BE) "Con la asignatura Prácticas del Lenguaje lei muy poco, te soy sincera. Eso lo manejan más las maestras. Yo me dedico a la atención de la biblioteca (...). Acá también tenemos juegos, tenemos con qué entretenerlos (refiriéndose a las niñas y niños)”.

("A"-BE) "Nadie tiene en claro el rol de la bibliotecaria escolar. A veces los maestros piensan que es una hora libre la hora en la que voy al aula para trabajar algún cuento. La docente se va. Yo soy un apoyo, estaría bueno que se quede, pero se va".

Y avanza esta bibliotecaria en su discurso, ofreciendo elementos para identificar el núcleo problemático:

"Lo que te piden en la escuela es el acompañamiento del proceso de enseñanza con la maestra. El trabajo propio del bibliotecario que es el procesamiento de la información queda en segundo plano. Primero están los chicos. Mucho no me gusta. A mi me costó definir el rol porque antes era maestra".

Las intervenciones del bibliotecario escolar, en el marco del diseño vigente, establece un campo de acción que no se reduce al espacio de la biblioteca, en sentido estricto. El debilitamiento de las fronteras entre el espacio de biblioteca escolar y el trabajo áulico conlleva otras responsabilidades, otros medios y exige a los agentes escolares en la persecución de otros fines. La biblioteca escolar deja de existir -al menos en el plano de las teleologías- como un espacio secundario y se actualiza como escenario complementario en la tarea de formar lectores. Sin embargo, contradiciendo estas transformaciones, en algunos establecimientos el espacio de biblioteca escolar suele ser referido como un ámbito donde descansar de la ardua tarea como maestra de grado:

("F"-BE) "Vine a la biblioteca porque los chicos te cansan. Ya tengo un grado a la tarde".

En la misma dirección, es importante señalar que si bien algunas maestras de grado se hallaban realizando la formación como bibliotecaria escolar en Institutos Superiores de Formación Docente, dicha información no emergía en las situaciones de entrevista al ser interrogadas en torno a su formación y capacitación. Por el contrario, el título de bibliotecaria escolar aparecía en el discurso de estas maestras como un instrumento al cual apelar para "correrse" del trabajo áulico: 
("F"-MG-TM-4") "El día que me canse del trabajo con los chicos, me paso a biblioteca".

A las claras, esta perspectiva tiene consecuencias materiales: la de la existencia de un espacio de biblioteca escolar que se tornará renuente a la tarea de formación del usuario puesto que lo que se torna insoportable no es desempeñarse como maestra de grado sino la de trabajar con niñas y niños. Esta consideración, que pone el cansancio, no en la tarea realizada, sino en los sujetos a los cuales va destinada la misma acción, conduce a la exclusión de las niñas y los niños de un espacio de vinculación con el objeto libro. Recupero expresiones de los propios niños al respecto:

("F"-4 $\left.4^{\text {to }}-\mathrm{TM}\right)$ "La biblioteca la abren cuando quieren".

("F"-6 $\left.{ }^{\text {to }}-\mathrm{TM}\right)$ "No nos dejan venir a leer a la biblioteca".

("F"-4 $\left.{ }^{\text {to }}-\mathrm{TM}\right)$ "Te retan si vas".

Una situación observada en el espacio de biblioteca escolar de la institución anterior:

La maestra $\left(\mathrm{TM}-4^{\text {to }}\right)$ pregunta:

"¿Para qué venimos hoy a la biblioteca?"

Los niños responden a coro:

"Para trabajar las Efemérides"

Pero uno de los niños responde por lo bajo:

"Para hacer silencio, para eso venimos".

Durante la situación de trabajo en la biblioteca escolar, los niños sólo recibieron de la maestra y de la bibliotecaria escolar los textos escolares para buscar información relacionada a una fecha patria. Luego de la acción de repartir el material, ambas se sentaron en el escritorio, limitándose su presencia, efectivamente, a llamar la atención de los estudiantes que conversaban. Y ello, con independencia de la intención por la cual se comunicaban. Por ejemplo, se los hacía callar, incluso cuando el diálogo entre los niños se iniciaba por el interés puesto en la información leída ${ }^{29}$.

\footnotetext{
${ }^{29}$ Nota de campo, La Plata, Junio de 2012.
} 


\section{Biografías lectoras.}

Para iniciar el análisis correspondiente a las implicancias de la biografía lectora en el quehacer profesional de las docentes, apelamos a los planteos de Klein (2007: 13), para referir que los fragmentos provenientes de los discursos de los agentes escolares entrevistados no pueden constituirse en términos de historia lectora, ya que dicha imposibilidad radica en el hecho de que no constituyen un corpus completo. Sin embargo, a partir de conocer de modo fragmentario los primeros acercamientos de las docentes a los libros, la lectura y la literatura, fue posible identificar y analizar elementos que se reactualizan en las prácticas lectoras de las entrevistadas y en sus intervenciones como docentes.

A partir de ello, la autora apela a la conceptualización de narraciones orales, no para referirse al relato basado en la tradición oral ni a la historia de vida que se inscribe como metodología cualitativa en el vasto campo de los documentos personales en las ciencias antropológico-sociales, sino para incluir un conjunto más o menos ordenado de anécdotas, recuerdos personales o fragmentos de vida que narra el sujeto (Klein; ibídem).

De esta manera, será preciso considerar las trayectorias de lectura como resultado de una conexión entre prácticas y significaciones en un contexto, aunque reinterpretadas en relación con un tiempo y un lugar diferentes al original, pues ciertas transformaciones pueden acarrear diferencias significativas respecto de un tiempo presente (Ramírez Leyva; 2008).

Así, a partir de la historización del vínculo con la lectura, los libros y la literatura, los sujetos identifican en su pasado elementos que se re-actualizan en sus prácticas actuales. Ello sitúa a las trayectorias lectoras como una herramienta teórico-metodológica que contribuye a develar los significados que los docentes atribuyen a las diferentes prácticas lectoras, conduciéndolos a indagar sobre los sucesos en su pasado personal que influyeron e influyen en su configuración (Ferreyro y Stramiello; ibídem).

Nos remitimos, a continuación, a los discursos:

("C"-BE) "No fue una buena experiencia para mí el inicio como lectora. Yo vivía a la vuelta de la Biblioteca Pestalozzi cuando el edificio funcionaba en la vereda de enfrente y la atendía J. L que, además, era mi vecino. Cuando yo me portaba mal, mi mamá me mandaba en penitencia a la biblioteca. -iA sí?, me decía. -. Te vas con J. L. Yo le tenía pánico a él. Nunca me voy a olvidar el piso crujiente de madera de la biblioteca. Yo entraba abi, no sé, era un lugar fantasmagórico. Entraba y J. L. me decía: -Te portaste mal. Leé. Y yo leía. Y después me llevaba a casa. Y así fue como me empezó a gustar. Y mi madrina siempre para mi cumpleaños me regalaba un libro, alguna biografía 
de algún prócer. Y J. L. también me empezó a regalar libros para mi cumpleaños. El primero fue Tom Sanyer. Si bien mi ingreso a la literatura fue traumático, de adolescente me empezó a gustar leer. $Y$ le agradezco mucho a J.L.: él fue como mi alma mater (...).Tengo un desafí: leer la Divina Comedia. También me enganchan las novelas cortas infantiles. Y por más que pasen algunas semanas en las que no leo nada, necesito los libros en la mesita de lur. Necesito sentir que están, que son como una compañía”.

Podría decirse que existe una estructura mítica que enuncia la historia (Benveniste; citado por Agamben; 2007: 99-100) de los agentes escolares como lectores. Aquí interesa señalar que, a través de esta apelación al pasado, los adultos se re-presentan su niñez. Esta construcción exige un trabajo de invención por parte del adulto, en tanto que el niño que imaginamos haber sido no es sino la proyección del adulto que busca recuperar su pasado y que, al hacerlo, lo inventa de nuevo, una vez más. Por lo cual el niño (mi "niñez”) es antes sujeto de una estética que objeto de la razón (Alvarado y Guido; ibídem: 6).

En la multiplicidad de elementos que confluyen en la narración de la docente, en el intento por definir su constitución como lectora, se descubre que en esa búsqueda de sentido confluyen otros textos, provenientes del cotidiano vivir y de cómo este va dejando insignias en el cuerpo, y va tejiendo distintos textos que se multiplican y construyen una malla intersticial de ideas, acciones, etcétera (Pizarro; ibidem: 44).

En la narración de la docente, podría hablarse de cierta cinestesia que configura su experiencia singular como lectora. Y ello porque el acto de lectura no remite sólo a una actividad que involucra la vista sino que compromete, también, la audición, asida a un piso de madera que, indefectiblemente, cruje en cada pisada.

Por otro lado, en el relato aparece el miedo como experiencia subjetiva de la docente en su condición de niña. Dicho pasaje, en la narrativa de la entrevistada, me conduce a una frase de Julio Cortázar (2009: 211), la cual sentencia que "si el miedo me llenó de infelicidad en la niñez, multiplicó en cambio las posibilidades de mi imaginación y me llevó a exorcizarlo a través de la palabra".

A continuación, otro fragmento permite analizar los elementos configuradores de la trayectoria lectora de los docentes entrevistados.

(“A"-MG-TT-4") "Me leian mi mamá y mis abuelos y de grande también. Mi papá nació en Italia y mamá acá, y como bablaba mi papá mezclado, mi mamá se preocupaba para que mejorara. Yo empecé primero leyendo porque mi papá leia para aprender y no le gustaba que 
lo carguen porque hablaba mal. Sufrió mucho lo que la adolescencia por eso. Y se encontró con una novia y con el padre de una novia que eran lectores y lo empezaron a incluiry ahora ni la tonada se le nota. Y yo lo acompañaba (...). Yo siempre tengo libros, siempre estoy en alguna lectura que me saque de lo que es educación (...). El docente, para ser mediador, minimamente tiene que ser lector".

La lectura como práctica instrumental para erradicar todo vestigio de aquello que sitúe a un sujeto, individual o colectivo, como "otro", tiene su génesis en posiciones etnocentristas que caracterizaron la construcción del Estado-nación argentino siendo la escuela uno de los dispositivos, por excelencia, aplanadores de toda diferencia (Segato; 1998) concebida como indeseable.

El relato de la docente es portador de una discusión actual, aunque no novedosa y que continúa exigiendo, al decir de Bombini (ibídem), profundizar, desde las teorías de la lectura y la escritura, el conocimiento sobre los modos por los que ciertos bienes culturales se incorporan en la cotidianeidad de la gente, tanto en eventos de enseñanza formal como no formal e, incluso, en situaciones familiares.

A pesar de que la inclusión en la cultura escrita de la docente parece haberse forjado desde una perspectiva utilitarista, puede evidenciarse que el proceso vital de la cultura consiste precisamente en ser inagotable en la creación de mediaciones y transiciones (Cassirer; 1951: 8). Así, pese a la dimensión utilitarista, la lectura se instala a partir de vínculos familiares donde compartir un libro, acompañar a un ser querido en dicha práctica, nos informa de la inclusión de individuos a una comunidad de lectores, con sus requisitos y exigencias particulares.

("E"-BE) "Mi abuela tenía libros y yo me pasaba las tardes... por abi no entendía nada, pero los sacaba, los miraba... Y abi les tomé cariño a los libros. Esa es la base de una bibliotecaria (...). Yo voy a una biblioteca y me parece un universo a descubrir, saber qué hay abi, encerrado (...). Y a los libros siempre les encontrás cosas, porque vos estás en distintos tiempos, distintas etapas de tu vida y el libro cae distinto".

Hasta el momento nos hemos remitido a conceptualizaciones en torno a la formación de lectores, reconociendo que su condición de existencia implica una posición de sujeto asida a múltiples destrezas para vincularse con la palabra escrita (Ciriani y Peregrina; 2007: 61). Ahora bien, el libro como "cosa", el libro como objeto, el "objeto-libro", su presencia 
material, indudablemente constituye una instancia alfabetizadora que dista, generalmente, de las formas a través de las cuales niñas y niños se aproximarán durante su formación escolar.

La presencia material del libro desde los inicios de la vida del niño, es condición para que dicho sujeto devenga lector, en tanto se favorece una familiarización con dicho objeto. Es así que, cuando en el seno de un grupo familiar existe un adulto competente para constituirse como mediador natural, el libro ingresará primero como juguete.

Ya nos señaló Benjamin (1993) que el juego es la partera de todo hábito. En la narración de la docente, en el ejercicio repetitivo de sacar los libros y mirarlos, por más que "no se entendía nada", a través de ese juego repetitivo se (re)produce su historia como lectora. Y ello, porque el sujeto se constituye como lector a partir del reconocimiento material del libro como objeto: a través del contacto frecuente, de sucesivos acercamientos, se habilita un pasaje que va de la mera existencia de libros a la presencia de estos en una vida singular.

Pero, primero, hay que superar esa extrañeza inicial. Extrañeza que no necesariamente conlleva a la inacción sino que, por el contrario, motoriza una plena experimentación. Así, es habitual encontrarse con niñas y niños que, ante un número significativo de libros disponibles, decida apilarnos como si fueran una torre.

De esta manera, la extrañeza no deviene en distanciamiento respecto del objeto sino en soberana implicación del niño con este. Una niña de $1^{\text {er }}$ año responde cuando la portera le pregunta qué hicieron en la biblioteca: "Estuvimos "bibliotequeando". "Bibliotequeando". Tardé un tiempo en encontrarme con una frase que me permitiera comunicar la complejidad de la respuesta. La frase proviene de Joseph Brodsky (2011), un poeta ruso que en uno de sus poemas refiere: "tus sustantivos me verbalizan".

En el contacto entre sujeto-cuerpo y objeto-libro media, indefectiblemente, un tipo particular de afecto. La frase de la docente es más que elocuente: "Y abi les tomé cariño a los libros".

A continuación, extractos de actores diferentes, nos sitúan en un análisis de las biografías lectoras de los agentes escolares a partir de una perspectiva de clase:

("A"-BE) "Mis padres eran trabajadores los dos, asi que leía yo, por mis propios medios".

(“A”-MG-4 $\left.{ }^{\text {to }}-\mathrm{TM}\right)$ "Me leía mi mamá. Mi papá laburaba. No recuerdo ningún libro de los que me hayan leido. Si recuerdo mi primer libro de lectura en la escuela. Mi amigo Gregorio, se llamaba (...)". 
("F"-MG-3 ${ }^{\text {er }}$-TT) "Mi mamá no leía, menos libros. Era ama de casa, una mujer básica".

("A"-MG $\left.{ }^{2}-1^{\text {ero }}-\mathrm{TM}\right)$ Mis primeros libros fueron en la escuela. No babia plata en casa, $y$ mis padres no eran lectores. Mis primeros libros fueron de mis primas, con dibujos fascinantes y sin tapas (risas), pero fueron los primeros. Pero si bien no me leían mis padres, mi mamá inventaba historias o contaba los cuentos que sabia. Ella vivió en el campo, asi que me inventaba historias de animales o de sus mascotas".

En los extractos seleccionados se evidencia cómo la condición de clase trabajadora, quizás, no se vincula con la literatura a través del soporte impreso, del libro en tanto objeto. Cuando aparecen libros, los mismos son recordados como libros destartalados, "sin tapas", a la vez que ajenos, es decir, propiedad de otras personas. El acercamiento a libros impresos es efectuado en el inicio de la escolaridad primaria, a través de textos escolares destinados a la instrucción cívica y moral de los estudiantes (Wainerman; 2003).

Asimismo, en la mayoría de los extractos se establece un vínculo entre los referentes adultos y las niñas a partir de la literatura en su vertiente oral. Aquí priman, no sólo adaptaciones de cuentos tradicionales sino, además, relatos originales improvisados por los padres, canciones y anécdotas. La importancia de la oralidad es insustituible, en tanto a través de la actividad del lenguaje podemos encarar no sólo la realidad que está a nuestro alcance inmediato, sino mundos distantes en el tiempo y en el espacio y otros mundos imaginarios y construidos (Jaimes Carvajal; ibidem).

Massat y Alvarado (ibidem: 36) sostienen que una razón de que la literatura y la narración estén unidas al imaginario infantil tiene que ver con este poder de la ficción de suspender el tiempo real y permitir al receptor abstraerse del entorno para participar imaginariamente de la situación representada. En el relato que se expone a continuación, se muestra cómo una docente, cuando niña, es inscripta en los problemas históricos, sociales y humanos a través de las historias narradas por sus abuelos

(“A”-MG-1 $\left.{ }^{\text {ero }}-\mathrm{TT}\right)$ "Un buen lector no es por cantidad. Es porque disfruta. Es el que lee libros que lo invitan a leer otros libros. Es magia (...). A mi me leía mi mamá y a ella, mi abuela. Mi abuela y mi abuelo me contaban cuentos (se emociona, llora), y me relataban historias de Perón. De abi se me dio el gusto por la historia, seguro. Historias del frigorifico o de Cipriano Reyes (...). También recuerdo que leía a Conrado Nalé Roxlo. Pero creo que fue por Juan Ramón Jiménez que 
me empezó a gustar escribir. Me quedó re grabado. Y ahora me gusta ponerle todo el sentimiento a lo que escribo".

En el relato mencionado se evidencia cómo el ingreso a la literatura, al mundo ficcional de los relatos heredados, se produce, naturalizadamente, el ejercicio de la escritura. Y aquí coincidimos con Morey (citado por García Canal; 1998), quien sostiene que leer y escribir mantienen una estrecha tensión que a menudo se asemeja a una simbiosis: leemos porque escribimos y escribimos porque leemos; cuanto más aprendemos a leer más capaces somos de escribir, cuanto más sabemos qué es escribir mejor nos asentamos en el gesto de leer.

("B"-BE) "Acá en la escuela, las maestras me mataron cuando les dije que estaba leyendo (se refiere a un libro de auto-ayuda). Pero me acuerdo que mi mamá le decía a mi maestra si estaba bien que yo leyera revistas de Isidorito o de Paturuqú, y la señorita decía que no importaba qué leyera sino que leyera".

El énfasis en la lectura como ejercicio físico, es decir, la lectura mecanizada (Sardi; 2010), se explicita en el discurso de la docente, como práctica asida a su experiencia escolar. La práctica de la lectura se aprehende como un ejercicio que se adquiere por una repetición sostenida a lo largo del tiempo siguiendo ciertas reglas establecidas que favorecen la función modeladora de la escuela (Sardi; ibídem).

El fragmento referido permite trazar la distinción entre la alfabetización y la formación de lectores. Cuando la función de la escuela se reduce a la alfabetización, niñas y niños son entrenados como "copistas" que reproducen, sin un propósito propio, lo escrito por otro o como receptores de dictados cuya finalidad, también ajena, se reduce a la evaluación por parte del docente (Lerner; 1993).

El énfasis en la alfabetización no promueve el gusto por la lectura, ni otorga un margen para que el lector plantee sus intereses. Esta cuestión es problematizada en numerosos documentos elaborados por el sector educativo, atentos a la distancia entre las conceptualizaciones sobre la literatura producidas desde el campo de los estudios literarios y las producidas desde la comunidad de gestores (Gerbaudo; 2006: 85).

Sin embargo, la fuerza de los postulados escolares, materializados en la anécdota de la conversación entre la maestra y su madre, parecieran no haber sido interpelados o deconstruidos durante su formación profesional, ni como docente ni como bibliotecaria 
escolar. A través de la reconstrucción docente de situaciones de acercamiento a los libros y a la literatura durante su infancia, fue posible identificar el peso de estos recuerdos como elementos configuradores de su postura pedagógica. A partir de ello puede referirse que si bien las prescripciones curriculares orientan las intervenciones de las docentes, a través de una compleja combinación de tradiciones históricas, decisiones políticas y administrativas, planeaciones técnicas, entre otras (Pautano; ibídem), la interpretación que las docentes realicen de las directrices en torno al vínculo con la lectura literaria estarán supeditadas a su propia biografía lectora.

Algunos docentes refirieron no tener recuerdos relacionados con la lectura literaria e, incluso, afirmaron que no les gusta leer literatura. Sin embargo, el conocimiento técnico de los documentos que configuran su práctica profesional, la apropiación de ciertas pautas generales para estructurar el proceso de enseñanza, posibilitaban una posición docente que efectivamente favorecía el acercamiento de los alumnos a la literatura.

A continuación, un ejemplo:

("E"-MG-1" ero-TM) "No soy amante de la literatura. No tengo recuerdo de haber leído un libro de chica. Y abora no leo porque me aboco mucho a lo que es la profesión y me encierro. El diseño (curricular) me lo voy a saber, las circulares me las voy a saber, los documentos y las estrategias me las voy a saber. Pero la literatura no me interesa, me aburre. Pero por una cuestión de respeto a los pibes les leo (...). Me gusta traerles libros, muchos, para que ellos elijan. A principio de año pedí \$10 y me fui a la Feria del Libro. Compré un total de 20 libros. A fin de año, reservo 10 libros para los chicos que ingresen a $1^{\text {ero }}$ y cada chico que egresa, se lleva un librito".

"La literatura me aburre", refiere la docente. Sin embargo, continuando con la entrevista refiere con entusiasmo:

"Una vez. leimos Un elefante ocupa mucho espacio"; me re enganché proponiéndole a los chicos conversar sobre qué representaba, a nivel social, cada personaje. No sabés la conversación emocionante que se armó: todos querían opinar".

A partir de este fragmento es posible reconocer que si bien la literatura puede no estar incorporada en el bagaje cultural del docente, su inserción en una red institucionalizada de

\footnotetext{
${ }^{30}$ Bornemann, Elsa (1975). Un elefante ocupa mucho espacio. Ediciones Librerías Fausto.
} 
inter-reconocimiento le permite obtener provecho material y simbólico (Hernaiz; s/a). En este sentido, su vínculo particular con los alumnos a cargo, el interés porque estos lean y participen, favorece situaciones áulicas en las cuales el uso del texto literario no se encuentra supeditado a los términos instrumentales o morales, en pos de un mensaje prescriptivohigienista o cívico-nacionalista (Gerbaudo; ibídem).

Tampoco predomina en la propuesta un enfoque escolarizante del texto literario, supeditado a la lingüística sino que, por el contrario, la propuesta motiva una búsqueda cooperativa de sentidos, ni únicos ni unívocos, a partir de la problematización de las instituciones, a la vez que inscribe a los alumnos en el debate en torno a problemas comunes, tales como la lucha por la libertad, las formas de dominación entre los hombres, entre otros. De esta manera, a pesar de su vínculo personal con la lectura literaria, la docente inscribe una propuesta de intervención junto a sus alumnos desde un enfoque teórico contemporáneo, a partir del cual incluye, como variable de análisis al sujeto, el poder, la política y la ideología (Gerbaudo; 2006: 89).

Aunque fragmentarios, los discursos hasta aquí referidos nos permiten identificar elementos que contribuyen a develar los significados que los docentes atribuyen a las diferentes prácticas lectoras, a partir de un ejercicio reflexivo que los conduce a indagar sobre los sucesos en su pasado personal, que influyeron e influyen en su configuración (Ferreyro y Stramiello; ibídem).

Esta afirmación se explicita, de manera elocuente, en el discurso de una docente:

("F"-MG-1" ero-TM) "Cuando respondia las preguntas" que se relacionaban con la entrada del libro y de la lectura en mi vida, me fui acordando de la imagen de mi papá leyendo el diario en la mesa de la cocina. A la mañana y a la tarde leía el diario. Y yo, mientras escribía, iba recordando y viendo esa imagen de mi viejo, y me empecé a preguntar si no era esa imagen la que, de alguna manera, inconscientemente, se repetía cada vez que yo leía. Si no era por esa imagen que yo leía, que yo le empecé a dar valor a la lectura (...) Gracias por hacerme responder esas preguntas, me bicieron recordar muchas cosas".

A partir de este relato puede evidenciarse cómo ciertos rituales dejan huellas imborrables que trazan ciertos recorridos lectores o experiencias de lecturas futuras (Sardi; ibídem). Introducir la pregunta en torno a cómo apareció el libro y la literatura en la vida de

\footnotetext{
${ }^{31}$ La docente se refiere a un cuestionario auto-gestionado que le solicité respondiera en su hogar, dado que no disponía de tiempo para realizarlo en el establecimiento durante las horas especiales.
} 
cada docente favoreció una instancia donde ellos mismos pudieran pensarse en los márgenes de su profesión y también construir cierta poética en torno a su infancia.

Los sentimientos y las emociones permearon las respuestas puesto que hablar del vínculo de los agentes escolares con los libros y la literatura obligó a recordar familiares que fueron trazando, desde la oralidad, el reconocimiento del lenguaje a través del juego. También porque recordar el estado de los primeros libros con los que se encontraron en sus casas (heredados de otros familiares, rotos, viejos, sin tapas) o la ausencia de padres que les leyeran, se relacionaba íntimamente con situaciones que, posteriormente, pudieron reconocer como privaciones materiales y/o afectivas y que se reactualizaban en la situación de entrevista.

\section{Entre los criterios de selección literaria y la construcción del sujeto lector.}

Como dimensión constitutiva del análisis de las condiciones que efectivizan la democratización o no del acceso a los libros, la lectura y la literatura, se inició un trabajo de identificación de las representaciones y prácticas que, a través de un juego de oposiciones y semejanzas, trazaban la desagregación o no entre un sujeto escolar y un sujeto niña o niño.

Por ello, interesó reconocer los usos y sentidos que los docentes otorgan a la lectura literaria y a las prácticas de lectura, identificando, describiendo y analizando las intencionalidades que motivan la inscripción de los textos literarios en las situaciones áulicas. En este sentido, aprehender cómo los docentes fundamentan la selección de un material determinado exigió analizar el mapa de niño que dichas docentes poseen.

En este apartado nos interesa identificar nexos entre los elementos que participan en la selección de textos literarios, las representaciones en torno a los sujetos destinatarios de sus intervenciones y los modos particulares de abordar la literatura en situaciones áulicas y extraescolares. En este sentido, a partir de los resultados obtenidos es relevante mencionar que, al indagar en torno a instancias donde las docentes hayan accedido a la lectura literaria, ninguna menciona su trayectoria de formación como un escenario que brinde dicha oportunidad. Los criterios de selección de un determinado texto literario se cimientan, indefectiblemente, sobre las representaciones de infancia y de lector. Estas representaciones motivan prácticas específicas y, en tanto constituyentes de tendencias ideológicas particulares, son discursos y 
creencias que se conectan con la estructura de poder o con las relaciones de poder (Eagleton; 1998: 27) constitutivas de los escenarios escolares.

A continuación, se exponen fragmentos de discurso y situaciones diversas observadas y registradas durante el trabajo de campo que hicieron posible la reflexión sobre las matrices a partir de las cuales los agentes escolares valoran, no sólo los textos literarios, sino también la condición de sus estudiantes como lectores. Asimismo, interesa comprender a partir de este desarrollo, que las relaciones con el lenguaje y la experiencia del estudiante constituyen una dinámica cultural en la cual los estudiantes vienen a experimentarse a sí mismos como sujetos (Giroux y Mc Laren; 1998: 137).

Es desde esta perspectiva que conviene pensar si la calidad de la interacción del maestro con los alumnos no disminuye debido a la distancia entre las expectativas del docente y las prácticas efectivas de los niños dentro y fuera del contexto escolar (Michael citado por Iturrioz; 2010), mediadas por simplificaciones o naturalizaciones, asociadas a identidades, experiencias, sentidos comunes y apropiaciones culturales diferentes.

Un ejemplo para ilustrar lo anteriormente referido:

("D”-MG-4 $\left.{ }^{\text {to }}-\mathrm{TM}\right)$ "(refiriéndose a los alumnos) No son lectores. Uno les da la posibilidad que lleven el libro para que vayan leyendo la lectura que uno les indica, y no la traen leída. No les interesa la lectura y, por más que una insista, tienen otras cosas que les interesan, como Facebook, están re enganchados con eso, por la música de moda".

La elocuencia de este discurso nos señala, implícitamente, que los alumnos presentan un desinterés generalizado por la cultura en el sentido más usado del término, es decir, "lo culto”, y no en sus acepciones antropológica y sociológica modernas (Cuesta; 2006: 62). ¿Qué música escuchan esos niños? ¿Por qué la docente, estratégicamente, no establece una correlación entre las canciones y la poesía? ¿Qué filtros operan distanciando al lenguaje poético de la canción y la música?

Los interrogantes planteados nos sitúan en la indivisible relación entre la formación literaria del maestro y la formación del maestro como lector de literatura (Actis; ibídem: 52-53), la cual es postergada, no en la currícula, pero sí en el proceso real de formación de profesionales docentes.

La misma docente continúa expresando: 
"Hay una lista (se refiere a las recomendaciones de lectura explicitadas en el diseño curricular correspondiente a cada ciclo) donde se dice qué libros se les puede leer a los chicos. Pero yo no tengo tiempo para leer muchos libros; y los chicos tampoco lo pueden elegir. Asi que por eso los elijo yo".

En el fragmento expuesto, la recomendación curricular evidenciada en la frase “... donde se dice qué libros se les puede leer a los chicos", es apropiada por el agente escolar como prescripción sin reflexión. En este sentido, no basta siquiera con elegir un libro de calidad literaria, avalado por el sector educativo: es necesario, además, contar con herramientas que favorezcan la construcción de un espacio donde un texto sea percibido como "literario". De lo contrario, la literatura ingresa en el cotidiano de niñas y niños, en su condición de alumnos, como un objeto normalizado (Foucault citado por Gerbaudo; ibidem: 91).

Otras consideraciones en torno a las prácticas lectoras de niñas y niños, centradas en el déficit y la cuantificación, se materializan en los discursos de la siguiente manera:

(“A"-MG-4 ${ }^{\text {to }}$-TT) "El problema es siempre la falta de lectura (...). Prestan atención a la vocal que están leyendo y no prestan atención a lo que realmente es el texto, porque vos les hacés una pregunta y no saben lo que leyeron (...), porque bay buenos lectores pero no saben lo que leyeron. En el segundo ciclo ya se pierde la lectura, esa que adquieren en los primeros años (...).

El reconocer que existe una pérdida de esa lectura que los niños adquieren en los primeros años, no agota los elementos que interrumpen su continuidad y desarrollo. Y mucho menos arroja hipótesis en torno a las formas particulares de leer de los niños cursando los niveles iniciales de la escuela primaria. La docente en cuestión sitúa el interés por leer en los niños del primer ciclo, en oposición a "los chicos del secundario (que) terminan diciéndote que leer es una porquería”.

Se expone a continuación, articulada a un extracto de entrevista, una situación concreta con la intención de mostrar intervenciones que obturan el disfrute de ciertos objetos por parte de niñas y niños:

("F"-MG-4"-TM) "Estuve trabajando bistorieta con los chicos, pero ya no, porque es muy difícil trabajar historietas. Cuesta mucho con ellos...”. 
Previamente, con motivo de presentarme ante los niños de la clase, les solicitó a sus alumnos que me explicaran qué habían aprendido leyendo historietas. La docente realizó preguntas del tipo: ¿cómo se llaman los cuadritos?, ¿cómo se llaman los sonidos que aparecen escritos? ? $^{32}$

Poco después me enteré que en dicho grupo se había trabajado una versión de la fábula "La zorra y la cigüeña" en formato de historieta. En correlato con la tradición escolar, el énfasis del cuestionario que la docente realizó oralmente junto a los alumnos, consistió en definir cuál era la moraleja de la historieta. De esta manera, una cuestión no explorada por dicha docente es la de recuperar qué experiencias con dicho género tenían los niños. Experiencia frecuente pues, generalmente, ellos tienen acceso a revistas infantiles, que se exhiben en puestos de diarios, las cuales presentan historias en el formato señalado.

En síntesis, desde la intervención docente, asida a la identificación de definiciones conceptuales, se obtura la posibilidad de problematizar la historieta como lenguaje, habitando tanto el lenguaje escrito como la textualidad que emerge a partir de las ilustraciones. Interesa la situación áulica referida en tanto registra la puesta en juego de una cierta "lógica del retaceo" a partir de la cual se propone, de acuerdo con lo que se cree son los intereses y las capacidades de los distintos sectores, una jerarquización de los bienes culturales (Negrín; 2011: 201-202). Esta jerarquización, siguiendo a Negrín (ibídem), operará distribuyendo los saberes y objetos de acuerdo con peligrosos determinismos que tienden a considerar que ciertos objetos culturales sofisticados no son de fácil recepción en contextos escolares críticos, o resultan superfluos para chicos y jóvenes irremediablemente condenados al fracaso.

Los criterios de selección de un texto literario y las representaciones del sujeto destinatario, no sólo relacionadas a su condición de niñas o niños, sino también a otras variables tales como clase, género, comunidad de pertenencia, entre otras, entran en tensión; pero son escasos los docentes que recuperan, en ese movimiento, los significados en torno a la lectura, particularmente literaria. En este sentido, el imperativo educativo de enseñar a leer no problematiza la pluralidad de sentidos que posibilitarían generar una ruptura con la tradición que lo reduce a la alfabetización, en tanto práctica meramente técnica. Ello posiciona al docente desde un lugar de monitoreo del ritmo y la fluidez de la lectura, que poco se interesa por los cambios que el aprendizaje de la lectura genera en la niña o en el niño.

\footnotetext{
${ }^{32}$ Nota de campo, La Plata, Noviembre de 2012.
} 
A continuación, un fragmento de entrevista expone cómo se complejiza la relación entre criterios de selección y representaciones del sujeto destinatario, cuando el agente escolar recupera reflexivamente el significado de leer:

("A"-MG $\left.\mathrm{MG}^{2}{ }^{\text {ero }}-\mathrm{TM}\right)$ "Leyendo se ve más allá de lo evidente, que es lo que pasa cuando uno lee (...).

A partir de este enunciado, se insiste en una conceptualización de alfabetización en tanto referencia a la aptitud de crear y comprender mensajes impresos y también a los cambios que produce esta aptitud (Cook-Gumperz; 1988: 33). La lectura, particularmente literaria, es valorada desde el discurso de esta docente como recurso que, contra el lenguaje rutinario de todos los días que automatiza nuestras representaciones de la realidad y nuestras respuestas a ella, nos obliga a darnos cuenta del lenguaje, refrescando las respuestas habituales y haciendo más perceptibles los objetos (Eagleton; ibídem: 14).

La misma docente continúa reflexionando a partir de la pregunta respecto a los criterios que guían la selección de un texto literario para sus alumnos, pero sosteniendo la prioridad por definir qué significa leer:

"Yo creo que se aprende a leer leyendo. Pero si no leemos, igual se aprende a leer pero el interés es otro: se lee por compromiso. Yo por eso leo bastante sin actividad posterior. A veces hay escritura, pero muchas veces nos quedamos sin comentar, para que cada uno imagine, o lo que tenga ganas de decir".

Cuando la problematización del docente respecto a su práctica alcanza el orden de la representación en torno a lo que significa leer, lo que efectivamente se desordena es la égida escolar tendiente a producir subjetividades uniformes. Así, el docente como mediador favorece la presencia de la literatura respetando un espacio subjetivo no susceptible de uniformización. Ello deja paso a la magia de lo que no se puede prever y de lo que no se puede atrapar de lo vivido, lo cual se conserva maravillosamente fuera de las palabras (Bollini; 2007).

(1 $1^{\text {ero }}$-TM) "Material hay, pero no estamos acostumbrados a trabajar con la bibliotecaria escolar; $y$ tal vez, falte un poco de inversión: salirse de las colecciones del tipo Mis Animalitos, que no es literatura de autor. Todos los libros son valiosos, pero hay literatura que es más valiosa que otra (...). La literatura es un mundo donde los chicos pueden pensar, y pensar lo que tengan ganas, con 
toda la libertad que les da la edad que tienen. Y tienen una imaginación terrible, y la imaginación es un ámbito necesario para explorar y los docentes tenemos que ser el puente hacia ese lugar que les abre puertas".

Interesan los aportes de esta docente en tanto trazan la diferencia entre la materialidad del libro, el soporte textual, y lo que efectivamente se entiende como literatura, es decir, el punto de de encuentro ente una obra y un lector (Moreno Arteaga; ibidem).

Cuando la entrevistada se refiere a la literatura de autor, se percibe claramente, al decir de Andruetto (ibidem: 9), un intento por canonizar, es decir, seleccionar, fijar, detener y preservar, que va unido a la docencia y que establece las coordenadas a partir de las cuales se puede discutir qué es relevante enseñar y, a la vez, preguntarse acerca de cómo seleccionar las lecturas de los programas escolares.

Para García Canal (ibídem), el orden de las palabras obedece a exigencias arquitectónicas espaciales. Por ello, cuando la docente refiere que "la literatura es un mundo", subyace un interés por reconocer que la espacialidad interior a la propia obra provoca configuraciones singulares (García Canal; ibídem). En este sentido, coincidimos con Pizarro (ibídem: 51-57), quien explica que el lenguaje es un camino que nos lleva a nosotros mismos, pero para ello es necesario que se ofrezca la posibilidad de cavar en la norma un espacio propio mediante la puesta en juego de ciertas herramientas, ciertas estrategias que nos obliguen a desacomodarnos para hacernos llegar a zonas no habituales de nosotros mismos.

Así, cuando una docente atiende a sus intervenciones reflexivamente, a través de un registro escrito de sus clases o recuperando diversas situaciones apelando a la memoria, y pone a su vez en tensión aspectos que refieren a su formación docente y a su construcción como lector, se produce lo que Fenstermacher y Deleuze (citados por Gerbaudo; ibídem) denominan una "buena enseñanza". Los autores mencionados, a partir de dicha expresión, intentan identificar aquellos sucesos donde el docente puede justificar en términos teóricos y epistemológicos por qué aquello que intenta transferir es importante que el estudiante lo "conozca", lo "crea" o lo "entienda" (ibídem). Para ello, nos remitimos nuevamente al discurso de la docente en cuestión, cuando se le pregunta qué criterios tiene en cuenta para elegir un texto literario:

(“A”-MG-1 ${ }^{\text {ero }}$-TM) "El cuento tiene que gustarme a mi (risas). iQué pregunta! No me la habia hecho nunca. Siempre les cuento la motivación que me hizo traerlo: que estaba en mi 
casa, porque me gusta el personaje o porque pensé que les iba a gustar. A veces, también les invento el motivo por el cual les traigo un cuento".

Desterritorializarse del espacio escolar, es decir, mostrar a los alumnos las propias lecturas por fuera de las fronteras trazadas por ese espacio, posibilita que los saberes circulen en el grupo, situando la posibilidad de la práctica lectora en otros contextos, tal como el espacio privado, doméstico. Ello, además, permite dotar de sentido la actividad de lectura propuesta por el docente, al explicitar las razones que motivaron la selección de un texto literario particular. Asimismo, "mentir" sobre el motivo de la elegibilidad de un cuento, se convierte en recurso que ficcionaliza la práctica docente, complejizándola. Y ello porque se favorece el ingreso de otros elementos que atraviesan el texto propiamente dicho y construye las condiciones a través de las cuales se instala un ambiente particular para la lectura.

Apelamos a otro discurso docente, en pos de avanzar en la reflexión en torno a los criterios de selección de textos literarios explicitados por los agentes escolares:

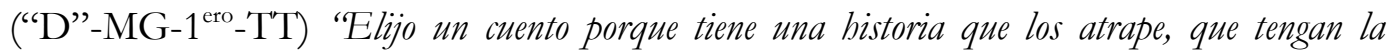
ilusión que todo va salir bien; no que tenga una parte triste (...). Los chicos necesitan algo que les agrade. Bastante la sociedad les muestra la parte negativa".

La literatura como embellecimiento, embellecer a través del lenguaje la presentación de la realidad, es una concepción de literatura difundida en el texto de la Ley Federal de Educación (Gerbaudo; ibidem: 82). Reducir el lenguaje poético a lo "bello" significa, también, reducir la experiencia estética que favorece el encuentro con la literatura.

Si ponemos en tensión el enunciado de la docente con el campo de estudios literarios, podremos comprender que el lenguaje en su función poética escapa al significado y se diferencia de cualquier saber, ya que es el lugar mismo donde se destruye y renueva el código social dando así salida a las angustias de su época (Kristeva; 1988: 258).

Asimismo, interesa este fragmento en tanto esboza núcleos problemáticos en torno a la censura y/o tabúes de ciertos temas, no sólo porque la temática es considera inapropiada desde la perspectiva del docente, sino porque la forma de construir ficcionalmente ese tema resulta reprochable. $\mathrm{O}$, por el contrario, cierta literatura ingresa como propuesta de lectura porque tendría efectos "benéficos", ya que aborda problemáticas asociadas al cotidiano de los propios niños: 
("F"-MG-5"-TT) "Elegi para leerle al chico Los Miserables, porque viste que la historia empieza con un robo, y como ellos vienen de barrios complicados... Es para que vean que está mal”.

El extracto anterior se conecta con el siguiente fragmento, el cual nos permite continuar reflexionando respecto a los elementos que condicionan, y a su vez argumentan, la selección de textos literarios:

("F"-MG-4"-TM) "El cuento tiene que tener un vocabulario adecuado. No se van a sorprender por una mala palabra, pero tratar que sea un vocabulario adecuado para las escuelas".

Al pensar en términos de adecuación a la institución escolar, no sólo nos habla de ciertas representaciones cristalizadas en torno a la escuela, sino que nos advierte sobre un posicionamiento del docente que, en tanto mediador de literatura, le quita centralidad a las niñas y niños como destinatarios. Y ello tiene correlato histórico con la formación pedagógica, la cual estuvo más vinculada al control de la clase que con el trabajo sobre sus imponderables (Cuesta; ibídem: 59).

Para ello, apelamos a otro extracto, donde se visualiza enfáticamente la cuestión de lo políticamente correcto en el marco de la selección literaria:

("F"-MG-4"-TM) 'Los chicos querían bailar cumbia villera por lo cual tuve que trabajar sobre el lenguaje tumbero. Tienen muchos familiares detenidos y la salida del fin de semana es ir a la cárcel (...). Con la cuestión de la cumbia villera no queríamos decir: eso está probibido, sino ver si la letra está bien, si se puede decir de otra manera y por qué les resulta gracioso eso que dicen. Ellos tienen que escuchar cumbia porque son villa, dicen. Ser villero da más poder".

"Si la letra está bien, si se puede decir de otra manera", constituyen expresiones del control lingüística que ejerce la escuela sobre el lenguaje cotidiano que se desarrolla en la espacialidad barrial donde viven niñas y niños de sectores económicos vulnerables. Las letras de las cumbias devienen en un lenguaje a ser normalizado por la matriz escolar que brega por un lenguaje pretendidamente "adecuado".

A partir de ello, los agentes escolares identifican en dichas letras el fondo cultural sobre el cual se cimientan las relaciones de las niñas y niños que asisten a la escuela, sin que 
ello sea incluido como un recurso para problematizar las representaciones en torno a la pobreza, el delito, el consumo de sustancias, la violencia, el género, entre otras.

De esta manera, tal como explica el discurso seleccionado, no es necesario prohibir la presencia de la cumbia en la institución. A través de la instalación de un análisis binario, de buenas o malas letras, anclado en la moral del adulto y desde una perspectiva particular de clase, se ejerce una censura que convierte en anecdótica la potencialidad del lenguaje cumbiero y/o tumbero para constituir identidad. "Ser villero da más poder" porque, en el contexto de los conocimientos necesarios para transitar el espacio barrial, la utilización de este lenguaje establece marcas de pertenencia.

En uno de los recreos llegaron niñas y niños de $3^{\text {er }}$ y $4^{\text {to }}$ grado a la biblioteca escolar. Yo me encontraba leyendo unos libros que la docente de $1^{\text {er }}$ grado había solicitado a sus alumnos para leer en el marco del proyecto lector. Una de las niñas de $3^{\text {ero }}$ se acercó y me pidió que le leyera el libro que estaba en mis manos. El resto de sus compañeras la siguió. Inicié la lectura de una de las poesías, jugando con el ritmo durante la lectura. También comencé, gestualmente, a imitar los instrumentos de la orquesta que la poesía enumeraba. El movimiento y la risa de las niñas más pequeñas llamó la atención de los niños más grandes que estaban distanciados de las mesas, buscando unos manuales. Cuando menciono, en el largo listado de instrumentos, al "violín", los niños sueltan una risa que, rápidamente, tratan de ocultar. Sin embargo, se miran con complicidad, hablando por lo bajo. Una de las niñas pregunta por qué se ríen y los chicos no responden. Les pregunto si con "violín" se refieren a los violadores, a las personas que se meten con el cuerpo de otras personas, amplío y una de las niñas expresa: "en mi barrio hay muchos, trabamos la puerta"33.

La docente, al pensar la "inclusión” del lenguaje tumbero desde el parámetro de la adecuación a la situación escolar, excluye de la problematización lo que la sociología del lenguaje llamó “aceptabilidad", para explicar cómo la ubicación en la escala social del hablante determina qué es lo que puede decir y qué debe callarse, cuándo y dónde (Iturrioz; 2006: 79$80)$.

A continuación, interesa exponer un fragmento en el cual la selección del texto literario se halla supeditada a la potencialidad de este para capturar la atención del niño haciendo que lo verdadero, al decir de Rancière (2011: 166), ya no sea simplemente el revés de una ilusión, sino el objeto de un tráfico en el que su propia diferencia con la ilusión se desvanece.

(“A"-MG ${ }^{2}-1^{\text {ero }}-\mathrm{TT}$ ) "El cuento tiene que ser atrapante. Por eso me gustan aquellos donde hay sonidos y poner todos los gestos, y ahi se quedan como perdidos. Por eso hago el sonido de los golpes

\footnotetext{
${ }^{33}$ Nota de campo, La Plata, Septiembre de 2012.
} 
de puerta, por ejemplo, jse sobresaltan! También hago distintas voces...". "Ellos traen de sus casas cuentos para leer. A veces quieren que les lea un cuento y como ellos te lo piden, es ese el momento y tenés que aprovecharlo".

Expresan Massat y Alvarado (ibídem: 36), que una razón de que la literatura y la narración estén unidas en el imaginario infantil tiene que ver con este poder de la ficción de suspender el tiempo real y permitir al receptor abstraerse del entorno para participar imaginariamente del mundo representado.

En el final del citado extracto, se identifica cómo la demanda de la niñez tiene asidero en la presencia de la docente, la cual accede a leer el cuento cuando es solicitado por sus propios alumnos. Ello se contrapone a otros posicionamientos adultos que, en detrimento de la voluntad de los niños, imponen sus intereses y gustos coercitivamente:

("F"-MG-2 $\left.{ }^{\mathrm{do}}-\mathrm{TM}\right)$ "Estos pibes no entienden nada. Ya les expliqué que Caperucita roja fue el trimestre pasado, que abora es otra cosa, que estamos con brujas. Pero les cuento un cuento sobre brujas y cuando les pregunto qué paso en la historia, me empiezan a contar el cuento de Caperucita".

En el mismo establecimiento, recuerdo una situación de lectura en el $6^{\text {to }}$ grado del turno mañana, en el marco de la hora de lectura correspondiente al Proyecto Lector:

Durante el recreo, Nahuel me invitó al salón. Me dijo: "Vení a leernos algo". Consulté con su maestra y me dio permiso: "Dale, buenísimo. Estamos leyendo mitos griegos. Si venís vos, que sos hombre, capaz que los varones se enganchan porque no leen nada". Una vez en el aula, los chicos sacaron el libro de mitos griegos cuando la maestra lo ordenó. Cuando preguntó quién quería empezar a leer, le pregunté si antes no podíamos armar un círculo. Justifiqué la propuesta en que dicha disposición no sólo podía generar otro clima para la lectura, sino que ayudaba a que todos pudieran escucharse. Me dijo que no había problema, pero me sorprendió que fueran los niños quienes se resistían a modificar el orden de las mesas y sillas, siempre de frente al pizarrón. De todos modos, accedieron ante mi insistencia.

Una vez formado el círculo, le pregunto a la maestra por qué página del libro iban, ya que era un compendio de mitos griegos que habían empezado a leer en clases anteriores. Me responde que no sabe, que empiece por dónde quiera. Les pregunto a los chicos si recuerdan, si alguien marcó la página. Me responden que no recuerdan dónde finalizaron la lectura el último viernes.

Elegimos entonces un mito al azar. Rocío solicita leer, inicia la lectura, pero se pone nerviosa y la abandona. La aliento a continuar, pero se niega. Decido no insistir. David toma la iniciativa, leyendo bajito y lento, trabándose en aquellas palabras para él complicadas. Su lectura es silábica, va armando las palabras letra por letra y sus compañeros se cansan con el ritmo de su lectura y empiezan a distraerse y a 
murmurar. Una burla explícita cae sobre él: "no sabe leer". La maestra se encuentra sentada fuera de la ronda.

Entonces Agustín decide, una vez que David completó un párrafo, proseguir con la lectura del mito. Pero su lectura es más lenta y menos fluida que la de su compañero. Sus compañeros se ríen sin tapujos y, avergonzado, dice que no quiere leer. Le insisto diciéndole: "hace 5 segundos atrás, tenías todas las ganas de leer, si por eso pediste permiso para leer, porque tenías ganas". Y agregué, convocando a sus compañeros: "Acompañemos a Agustín haciendo silencio, por lo menos".

Agustín continuó leyendo y, cuando finalizó el tercer párrafo, lo interrumpí para darle paso a la lectura por parte de otro compañero. Le agradecí el que hubiera continuado leyendo el texto. Poco después, la maestra abandonó su escritorio por fuera de la rueda y, aprovechando un silencio, pidió leer ${ }^{34}$.

El registro de la situación áulica referido se opone, de manera abismal, con lo expresado por la siguiente docente:

("E"-BE)"Para primer grado elijo trabajar con imagen. Me apoyo mucho en la imagen, me gusta ver la cara cuando ellos miran las imágenes. Me dicen: ¿me mostrás? Para segundo ciclo, elijo bistorias que tengan muchos personajes, porque los chicos tienden a identificarse, a buscar mimetizarse con algún personaje. "Es una pavada, pero la seño les hizo un señalador a cada uno y yo creo que estuvo muy bien, porque como iban a leer una novela iban a ir por capitulos, leyéndola de аросо...”.

Atender a las expresiones de los niños, acceder a sus solicitudes, permite referirnos a una pedagogía, menos interesada en la generalización, y abocada más a las singularidades. O, por lo menos, problematizadora de los discursos monolíticos. A continuación, ejemplos de perspectivas docentes cuya mirada no sólo pone en juego sus representaciones acerca del mundo y de la niñez, sino que se compromete con otras formas de distribución de poder:

("E"-MG-1 $\left.{ }^{\text {ero }}-\mathrm{TM}\right)$ "Vos te vas dando cuenta cuál es el interés del grupo, hacia donde va a caminar el interés del grupo. Si le gusta más la oralidad, la escritura, los cuentos tradicionales".

("E"-MG-4 ${ }^{\text {to }}$-TM) "Para las vacaciones no les di tareas. Les propuse que se lleven un libro de biblioteca. El libro que teníamos para leer en clase, se lo leyeron en la casa también”.

\footnotetext{
${ }^{34}$ Nota de campo, La Plata, Agosto de 2012.
} 


\section{Sobre la imagen del niño lector y los criterios de selección de lecturas.}

Luego de este corrido, puede evidenciarse que, en lo que respecta a los criterios de selección de un texto literario, el que posee el monopolio del hecho de la palabra impone por completo la arbitrariedad de sus interrogantes, la arbitrariedad de sus intereses (Bourdieu; 1985: 119). Sin embargo, existen posicionamientos que, en la distinción de los límites simbólicos entre el sujeto alumno y el sujeto niño, posibilitan una existencia institucional que no corre pareja a la institución de la desigualdad (Gago y Stulwark; 2011: 226), sino que justamente favorece nuevas distribuciones de los roles y de las funciones socialmente cristalizadas.

Dos ejes se tornan centrales en esta instancia reflexiva. El primero, se sitúa en la imagen de niño que motivan las intervenciones de las docentes. El segundo, se erige sobre los criterios de selección literaria que realizan las docentes, lo cual posibilita sistematizar la funcionalidad del texto literario en los escenarios escolares.

En cuanto a la primera cuestión, existen representaciones que tornan al niño como un ser incompleto, que requiere ser moldeado y, en varias ocasiones, suele tildárselo de tonto o fabulador, cuando no mentiroso. En detrimento de esta forma de concebir la niñez, existen posturas docentes que consideran que niñas y niños son portadores de una mirada singular y legítima del mundo y que requieren acompañamiento. Las prácticas que se desarrollan desde esta representación de un sujeto en su condición de niño, bregan por ofrecerle herramientas que le permitan manejarse con relativa autonomía: y más aún cuando en sus hogares no cuentan con la presencia de adultos significativos que velen por su protección.

Respecto a la segunda cuestión, los usos y sentidos de los textos literarios en el espacio escolar pudieron ser sistematizados, identificando las siguientes finalidades: 1) Finalidad estética: aquí el principio estético se reduce al embellecimiento, primando la selección de historias "con final feliz", con escasa complejidad argumental y con una clara diferencia entre El Bien y El Mal; 2) Finalidad moral: la intención es construir cívicamente a un sujeto, adecuándolo a determinados cánones éticos y morales. Se pretende "enseñar a ser mejor persona", a partir de la selección de textos que promuevan la educación en valores; 3) Finalidad informativa: el uso del texto literario se encuentra supeditado al aprendizaje de elementos gramaticales y reglas ortográficas; 4) Finalidad pedagógica: bajo esta finalidad prima la centralidad por comprender las prácticas del sujeto destinatario de las intervenciones docentes. Interesa reconocer el bagaje cultural de niñas y niños, como sustrato a partir del cual 
elaborar propuestas acordes y significativas que permitan ampliar el universo lector de la niñez. En este sentido, el lenguaje poético es un objeto complejo que exige, para su apropiación, múltiples y constantes situaciones que favorezcan el encuentro lúdico de niñas y niños con los libros y la literatura.

\section{Sumario del capítulo.}

A partir del desarrollo del presente capítulo se evidencian posiciones negativas y positivas en función de las modificaciones curriculares. Asimismo, lo que interesa señalar enfáticamente es que, más allá y más acá de estas valoraciones, emergen en los escenarios escolares profundas transformaciones en el saber-hacer de las docentes.

Hay un cambio y hay reacciones diversas: algunas superfluas, pero también desplazamientos que conducen a interpelar funciones docentes asimiladas acríticamente o instaladas identitariamente, a partir de la rutinización y mecanización de la práctica profesional. Se identifican, además, posiciones ambivalentes, las cuales se expresan en frases tales como: "la propuesta es buena, pero me faltan herramientas", o aquellas posiciones que ponen como condicionante la falta de tiempo.

También es menester señalar la existencia de posiciones docentes más empáticas con los grupos junto a los cuales trabajan, primando un interés por recepcionar sus demandas, intereses y actitudes. En este sentido, las docentes acompañan a niñas y niños, en tanto estudiantes: algunas, poniendo énfasis en la metodología, proponiendo situaciones diversas de enseñanza, otras, revisando los contenidos y proponiendo nuevos. Incluso, apostando al trabajo cooperativo junto a otras colegas.

Se puede exponer que, como recurso implícito en la tarea de acercar a niñas y niños a lectura literaria, las docentes cuentan (o no) con el bagaje de historias y sensaciones aprehendidos durante su niñez. Se remarca que este cúmulo de experiencia, al momento de desarrollar la clase, tiene más relevancia que el propio recorrido formativo profesional.

Aquellas estrategias docentes que reproducen elementos de la tradicional forma de enseñanza de la Lengua y la Literatura enseñan a leer a sus alumnos, aunque evidencian amplias dificultades para formarlos como lectores, particularmente literarios. Esta tendencia, a su vez, suele complementarse con una postura docente tendiente a la moralización de la clase, utilizando al texto literario como dispositivo por excelencia para cumplir dicho objetivo. 
Las docentes cuya práctica no diluye al sujeto niño en el sujeto escolar, encuentran un componente imaginal que les permite comprender que existen diferentes concepciones de niño (Langeveld: 2005), de vínculos familiares y distintos modos de organizar el parentesco que pueden presentarse en sectores populares. Esto es percibido ya no en términos de "inadaptación", "desorganización" o "anomia", sino como modos alternativos de organización familiar vinculados a una cultura popular urbana (Colangelo: 2003). A partir de estas representaciones, las docentes pueden proponer estrategias de trabajo en correspondencia con las necesidades y trayectorias del grupo, sin recortar saberes significativos, a la vez que situar propuestas de trabajo lúdicas y afectivas.

La diferenciación entre sujeto-escolar y sujeto-niño permitió identificar un criterio que condiciona los modos de acceso a la lectura literaria. Para fundamentar esta cuestión es posible apelar a las entrevistas realizadas, en las cuales los sujetos usualmente definían la importancia de la lectura literaria con fines lúdicos y recreativos cuando en sus discursos empleaban el significante "niño" o "chicos" ( "...los cuentos para los chicos tienen que ser entretenidos, tener acción"). Por otro lado, cuando el significante "alumna-alumno" emergía en la situación de entrevista, inmediatamente las finalidades de las prácticas de lectura literaria quedaban relegadas a intereses instrumentalistas ("... leemos un cuento para encontrar los sustantivos, verbos, por ejemplo"), a orientaciones moralizadoras, ya que en situaciones áulicas se observó que al final del relato se les solicitaba a las alumnas y alumnos que explicitaran qué enseñanza quería comunicar la historia (incluso cuando el texto seleccionado no era una fábula). 


\section{Capítulo V: La niñez y la lectura: tácticas, resistencias, fugas.}

En este capítulo se pretenden instalar elementos provenientes del trabajo de campo, indagando en torno a la construcción de sujetos, niñas y niños en situaciones escolares, atendiendo a sus prácticas en la interacción con otros niños y/o adultos. Vale decir que estas interacciones a las que hacemos referencia están mediatizadas por saberes que no se gestan disociados de los sujetos que lo producen ${ }^{35}$ : lo cual nos invita a explorar y problematizar los supuestos ético-políticos, implícitos y explícitos, que orientan la acción de los actores (referidos en este trabajo como "adultos", “docentes", “educadores").

Asimismo, este trabajo intenta revisar las epistemologías tradicionales en tanto adolecen de inconvenientes estructurales para comprender lo distinto, para interpretar y explicar la realidad de la alteridad, cristalizándose una mirada adultocéntrica que no niega otros sistemas de conocimiento, sino que los jerarquiza, les atribuye grados de validez, los menosprecia y/o excluye (Lorente Molina; 2004). En este sentido, los discursos provenientes de sujetos, niñas y niños, en el marco de las interacciones escolares, suelen ser minorizados.

Una docente, elocuentemente, sintetiza el supuesto de que niñas y niños son portadores de "discursos menores" al afirmar: "Lo nuestro es lo real... Ellos viven en su mundo" De esta manera, los saberes producidos por niñas y niños son sometidos a la autoridad de los adultos, bajo la égida de las prescripciones y tutelajes del aparato escolar. Bajo las prácticas de minorización de los discursos de niñas y niños, dichos sujetos son reducidos a su condición de alumnos. A partir de ello, una batería de pruebas, basadas en la observación, en el control de respuestas y en la objetivación de la inteligencia, enfatizará su identidad de educando. Identidad supeditada al orden de los cuerpos y a un cúmulo de aprendizajes que le exigen al niño capacidad para insertarse en el mundo, en detrimento de construir un espacio singular en él.

\footnotetext{
${ }^{35}$ Pienso que una consecuencia de esta distancia entre el adulto y los niños, como consecuencia de la minorización del discurso de estos últimos, se asienta en la reducción de espacios aptos para que niñas y niños puedan representarse el mundo y sus relaciones. Y ello porque la capacidad del adulto de significar, de traducir lo que el niño vivencia, es fundamental, ya que es a partir de esa capacidad que las vivencias dejan marcas, se inscriben. Para esto, el adulto tiene que estar en conexión con el niño, pero operando con un funcionamiento complejo de significaciones. Así, el niño debe tener cerca un adulto que opere con otro funcionamiento, un adulto que fantasee y piense (Janín, Beatriz. Pictogramas del alma. En Página 12, 21 de Marzo de 2013. Disponible en www.pagina12.com.ar).

${ }^{36}$ Nota de campo, Escuela "F", La Plata, Noviembre de 2012.
} 
Interpelar estas representaciones que minorizan a las niñas y a los niños $\mathrm{y}$, al mismo tiempo, legitimar sus discursos en tanto construcciones que mediatizan visiones originales del mundo y que explican acontecimientos que hacen a su propio cotidiano, no es tarea sencilla.

En este sentido, se trata de pensar la infancia más allá del registro habitual de edad natural de la vida o de humanidad preformada, pasible de padecer representaciones sociales diversas, según la época y la geografía (de Lajonquière; 2013) e, incluso, más allá de las coordenadas institucionales que recortan la subjetividad infantil a la experiencia educativa. $Y$ ello si concebimos que el acto pedagógico tiene no como horizonte sino como premisa la constitución de un espacio donde niñas y niños singulares se encuentren con referentes adultos capaces de recepcionar sus demandas, deseos e intereses.

De esta manera, en el presente capítulo se mostrarán a algunas situaciones escolares que, a partir del registro de campo de la investigación realizada, nos aproximan al entramado relacional al interior del cual niñas y niños constituyen su subjetividad. Para tal fin, el desarrollo del capítulo se estructura a través de diferentes relatos breves que pretenden captar la perspectiva de niñas y niños sobre la literatura, en el marco del lenguaje y el contexto escolar.

Para orientar la lectura de este capítulo, se anticipa que el mismo se organiza en tres secciones. Un primer apartado, titulado Micro-relatos de prácticas lectoras, se aboca a las representaciones y prácticas de niñas y niños inscriptos en situaciones de lectura, particularmente literaria. Dicho desarrollo se preocupa por capturar formas singulares de apropiarse de los libros, la lectura y la literatura, más allá y más acá de las prácticas adultos: por ello se recuperan operaciones concretas de la niñez que develan la densa trama a través de la cual semantizan el mundo. El segundo apartado, titulado La cuestión de la procedencia: nacionalidad, pobreza y racialización, se asienta sobre el análisis de situaciones que involucran criterios tales como la posición de clase, la raza y la procedencia geográfica, relacionada esta última no sólo con el espacio barrial donde viven niñas y niños sino con las percepciones en torno a "lo extranjero". Prejuicios y estigmas relacionados a tales variables no se objetivaron en todas las escuelas, pero el énfasis de prácticas discriminatorias en el establecimiento $\mathrm{F}$ exigió una reflexión específica sobre dicha problemática. En el último apartado, Niña abyecta-niña monstruo: notas sobre una construcción singular de subalternidad, se identifica la edad y la generación como variables significativas en el análisis de las modalidades y condicionamientos que se le presentan a la niñez para ser incluida en los dispositivos vinculados a la promoción y protección de derechos, siendo la escuela uno de estos dispositivos relevantes para su 
implementación. Estos resultados son ampliados hacia el final del capítulo y se sintetizan en las conclusiones finales que cierran el trabajo de tesis.

\section{Micro-relatos de prácticas lectoras}

A continuación, se exponen relatos breves (Geertz, 1996) de situaciones y prácticas De lectura. Algunos, luego de ser narrados, exigieron un análisis. Otros, consideré, sin excluir cierta forma de análisis, eran elocuentes en su propio desarrollo ya que, a través de la forma de organizar y plantear el relato, subyacían aspectos implícitos y explícitos que evidenciaban una mirada no neutral: la del investigador y, por ende, un análisis a partir de los esquemas de percepción aprehendidos, es decir, teóricos.

Marguerite Yourcenar (1991) escribió: "He leído con frecuencia que las palabras traicionan el pensamiento, pero me parece que las palabras escritas lo traicionan todavía más”. Es así que decidí priorizar en este apartado un ejercicio que permita escribir lo observado, retratando situaciones sin pretensiones de agotar las explicaciones en torno a lo narrado. Por ello, sin desterrar de este trabajo la pretensión de producir conocimiento con intención científica, me amparo en aquella premisa que establece que la buena literatura es aquella que no necesita contarlo todo. Y así, doy paso a las formas singulares a través de las cuales niñas y niños transitan su cotidiano escolar. .

\section{1.}

Presté particular atención a Ramón el día que visité su salón para observar la hora de lectura libre, programada cada viernes al final de la jornada. Era la primera vez que ingresaba a un aula como observador. Pero los niños ya me conocían de los recreos, donde algunos se habían acercado a leer los libros que exhibía en el salón de usos múltiples.

Los que no me conocían preguntaron mi nombre y qué hacía en la escuela. Les comenté que era trabajador social, que durante casi dos años había trabajado con niñas y niños de todas las edades, "tratando de que estuvieran un poco mejor". Uno de los niños me interrumpió para decirme que tenía cara de escritor:

"Si fuera escritor, le pediría que me escriba un cuento sólo para mî", explicó cuando la docente le preguntó qué pasaría si fuera yo escritor.

Con la docente había acordado participar de la hora de lectura, contando algunos cuentos y leyendo otros. Tuve la suerte de empezar con la lectura de un texto que a todos les causó mucha gracia, lo cual funcionó como anzuelo para captar su atención durante casi toda la hora. Además, me pidieron que volviera a leerles el mismo relato al final de la sesión.

A todos les gustó el primer texto leído; a todos, menos a Rosalía, que dijo que la historia era para nenes chiquitos, que ella leía otras cosas. Más tarde me contaría la 
madre de la niña que en su familia se reúnen a leer La Biblia, y que siempre para los cumpleaños le regalan libros sobre mitos y leyendas.

El primer texto leído, lo reproduzco en su totalidad a continuación:

$$
\begin{gathered}
\text { Uh que lino }{ }^{37} \\
\text { para ser leído en voz alta. } \\
\text {-¿Mo me quelé? } \\
\text {-Chi. } \\
\text {-A mer... ¿cuánto? } \\
\text {-Muto. } \\
\text {-¿"Muto" o "muto muto"? } \\
\text {-Mutísimo....Achí! } \\
\text {-Uh, qué lino. } \\
\text {-¿Y mó? ¿Me quelé? } \\
\text {-¡Uh! Maquel chol. } \\
\text {-¿El chol nomá? }
\end{gathered}
$$

-El chol, la luna, lasteyas, la tiela...toro. Toro, toro, toro. Achí, má que toro nel nivercho

-Uh, qué lino...Amél, namun mechito.

-Tomá...muá.

-Oto.

-Muuá.

-Oto.

-Muuuuá.

- No, oto y oto y oto.

-Muá. muá, muá. ¡Milá que te como, ¿eh?!

-Uh, qué meio, ¿cherio?

-¡Chi! - ¿ ¿Y polqué meván comé?

-Polque choi...jun león!

-¡Uh, qué meio, chenor león! ¡Nome coma!

-¡Chi! ¡La como! ¡Aaah!

¡¡No! ¡Qué meio!

-No, no tena meio, era mabloma.

-Ya ché, cho tamén era mabloma.

-¿'Tonche? ¿'Te como?

$-i \mathrm{Y}$ chi!

-Am aam, ñam,ñam, qué lico, aam, ñam. Chatá. Te comí.

-¡Uh, qué lino!

-¿Yhora me quelés?

-Chi, muto, aquíntu pancha.

$$
\text { -¿Cuánto? }
$$

-Parichempre de parichempre.

-¡Uh, qué lino! Cho tamén.

- ¿Mamo pachear nela mano?

-Cho te chevo.

-No, achí cunto nelamano, men cherquita.

-¿Cómo cherquita?

-Chote poyo la cabecha aquí nelhombro, y mamo nela mano. Cuntito.

-Uh, qué lino, mamo. Chí, mamo. No, pelá queme peinun poco.

\footnotetext{
${ }^{37}$ Pescetti, Luis María (2004). Nadie te creería. Argentina, Alfaguara Infantil.
} 


\author{
-Palaqué tepeinás? \\ -Palachel la pelchona malina nel muno. Pala voch. \\ -Vochasós la pelsona malina nel muno, ¿nontendé? Cho...cho...chote quelo achí \\ como chos. Note vachá peiná. \\ -Mamo, mamól. \\ -Mamo cocha monita.
}

Ramón me interrumpió en la segunda historia que, en lugar de leer, había elegido narrar oralmente. Me interrumpió bruscamente porque la conocía. Escuchó las primeras frases y se sobresaltó al sentirse familiarizado con el relato, sabiendo que disponía con antelación del contenido y que podía salirse del lugar de oyente... Y convertirse en narrador. La maestra, que se encontraba fuera de la ronda, controlando la planilla de asistencia, lo regañó por haber "cortado" el relato ${ }^{38}$ : "iRamón, no interrumpas!", cuando en realidad estaba prosiguiendo la historia, sin saltearse ninguna secuencia.

Eso mismo le expresé a la docente: que Ramón no me había interrumpido, que estaba contando la historia. "Te escuchamos", dije, volviéndome hacia el niño, quien continuó hasta el final el relato.

En los días posteriores, Ramón se acercó a saludarme al momento de formar filas para el saludo a la bandera, dándome la mano. Me contó que el cuento lo conocía porque su hermano más pequeño lo había traído prestado del Jardín de Infantes.

Un día, en la sala de maestros, la Directora me dijo de Ramón:

"El padre no hace nada. Ya no lo llamamos más, ¿para qué?".

"La madre que se fue con otro tipo; no se bizo cargo de sus hijos".

"No se pone las pilas: va a repetir".

Y su maestra agregó:

"Hace cualquier cosa en el aula. Se pone a gritar. Grita como un loco, está loco. Dice que grita porque es La Llorona".

"No respeta ninguna regla: ininguna! Está como sacado".

"Ni siquiera trae los deberes hechos, ni los útiles".

La Directora me preguntó si tenía alguna propuesta para que la situación con Ramón cambie. Retomé lo que dijo la maestra de Ramón: que el niño imita a La Llorona. La maestra me respondió que habían dado esa leyenda cuando trabajaron "misterio" en la asignatura Prácticas del Lenguaje. Esperé que expresara "algo más al respecto", pero su intervención finalizó allí. Tenía la esperanza de que la docente recordara el relato de la Llorona y cuánto de esa historia y del personaje principal mantenía íntima conexión con la historia del propio niño, como analogía de su entorno familiar.

Retomando la cuestión de las estrategias en torno a la situación de Ramón, consulté si habían entrevistado a algún referente familiar alternativo al padre, que pudiera acompañar la escolaridad del niño. La Directora y la maestra me respondieron que no, que el Equipo de Orientación Escolar sólo había convocado al padre, el cual no tuvo buena predisposición para escuchar a los profesionales, por lo cual se desistió en mantener contacto con este.

La Directora se quedó pensativa y, al rato, informó:

"Si que bay otro familiar: la hermana de Ramón".

\footnotetext{
${ }^{38}$ Interesa reconocer la sanción que recibe el niño cuando asume u ocupa el lugar del narrador. Lugar que, desde la óptica benjamiana, es el lugar de la autoridad por excelencia. Desde el posicionamiento de la docente, la autoridad se basa más en el poder que deviene de la relación asimétrica entre adultos y niños, y no en las funciones que debe realizar en pos de responsabilizarse de los sujetos a su cargo (Bleichmar; 2006: 143-144).
} 
Pensé que se refería a una hermana adulta del niño, pero no. La Directora se refería a una hermana del niño que concurría al mismo establecimiento, un año más grande que él. Le expresé que no me parecía pertinente hacer responsable a una niña de otro niño. Pero la Directora desoyó mi reprobación en relación a su intervención e inmediatamente mandó a llamar a la niña a la dirección, para comunicarle que desde ese día iba a estar encargada de "controlar las tareas de su hermano menor".

Tuve la oportunidad de compartir con Ramón un tiempo de lectura en la biblioteca escolar, durante la hora de clase, ya que la Directora y la maestra decían que conmigo andaba más tranquilo. La primera vez nos sentamos enfrentados en dos sillas, separados por una mesa pequeña donde apoyamos el libro que íbamos a leer. En la segunda situación, también en la biblioteca, apenas entramos el niño se adelantó para disponer las sillas y la mesa del mismo modo que la vez anterior: dos sillas enfrentadas, separadas por una mesa. Y recordé que de Ramón se decía que no incorporaba ninguna regla.

\section{2.}

Magisterio: profesión feminizada ${ }^{39}$. Por ello, quizás, a lo largo del trabajo de campo sólo tuve la oportunidad de conversar con un solo docente. A continuación, el registro de las situaciones de interacción con dicho actor y sus estudiantes a cargo, cursando el quinto grado.

"No, disculpá pero no voy a completar la encuesta. No te voy a mentir, porque me la voy a llevar a casa y no la voy a completar. Me voy a colgar. Yo empecé a leer porque empecé la escuela; en casa no habia libros. Hice un curso con una profesora, estuvo muy bueno".

Le comenté que era de los pocos docentes que había realizado un curso específico sobre literatura infantil y me contestó que le había gustado la parte de libro-álbum ${ }^{40}$ que la profesora que dictó el curso les enseñó a leerlos, mostrando cómo convenía acomodarse para que todos pudieran ver las imágenes.

Aproveché ese comentario y saqué de mi bolso un libro-álbum que recientemente había adquirido, titulado Hay día ${ }^{41}$. Y le dije que aceptaba que no completara la entrevista, pero que me gustaría leyera el libro y me comentara qué le había parecido. $\mathrm{Al}$ otro día, el maestro me dijo: "Les lei el libro que me diste, me gustó y les gustó. No lo entendieron de una, pero me pidieron que se los volviera a leer. Les gustó, creo, por la conversación entre la mamá y la nena, y porque tienden la ropa juntas, cosa que les puede haber resultado cotidiana. Esas cosas gustaron. ¿Hay más libros de esa autora? ¿Querés venir a la hora de lectura hoy? Es ahora, apenas entramos al salón.

$\mathrm{Y}$ fui.

\footnotetext{
39 En torno a la feminización de las profesiones, interesa señalar que tanto el Magisterio como el Trabajo Social comparten su condición de ser profesiones gestoras de "lo doméstico de lo público" (Lorente Molina, Belén. Género, ciencia y trabajo. Las profesiones feminizadas y las prácticas de cuidado y ayuda social. Revista Scripta Ethnologica, año/vol. XXVI, Consejo Nacional de Investigaciones Científicas y Técnicas, Buenos Aires, Argentina, pp. 39-53).

${ }^{40}$ Actualmente se puede hablar de dos tipos de libros infantiles ilustrados: están aquellos en donde las imágenes tienen como función acompañar literalmente el texto y aquellos en los que la ilustración apoya la construcción del sentido del texto. En este segundo grupo se ubican los libros-álbum. Se caracteriza porque utiliza estos dos códigos -la imagen y el texto- para contar una historia. El texto y la imagen se complementan para dar la posibilidad de construir diversos sentidos, la estética de la palabra y la imagen lo permiten (Nakamura Aburto, Laura y Peralta López, Víctor Manuel. El libro-álbum y las intervenciones docentes. Revista Novedades Educativas, n 165, Septiembre de 2004, pp. 18-23).
} 41 Wernicke, María (2012). Hay días, Buenos Aires, Calibroscopio. 
Al llegar a la puerta del aula los niños estaban afuera e inmediatamente me preguntaron si era el narrador (estaba programado un encuentro para el mes de Agosto con una cuenta-cuentos).

Me presento pues, en el turno tarde, sólo había asistido como observador contadas veces y aún no había participado en dicho curso.

Los niños me cuentan que en la casa no tienen libros, y que tampoco conocen bibliotecas cerca de sus hogares. Juan Manuel me comenta que en el cajón de su mesa de luz tiene algunos. También conoce una biblioteca, pero no va. A pesar de que le gusta mucho leer durante las horas de Prácticas del Lenguaje.

En el aula, para la hora de lectura, el maestro los hace sentar en ronda. Una vez acomodados, el maestro me presenta formalmente, diciendo que soy trabajador social. Les explico a los niños que estoy en su escuela porque me interesa conocer qué leen los chicos, qué les gusta leer y qué no. Ellos tienen en el aula una biblioteca sin organizar, pero hay un niño encargado de registrar los préstamos, anotando el nombre del compañero y el título que se lleva a domicilio.

En una de las paredes del aula, hay un afiche extenso donde docente y estudiantes escriben con marcador las recomendaciones de los libros que leen. Les señalo el afiche y los chicos, inmediatamente, empiezan a contarme cuáles son sus lecturas favoritas. El docente también nombra algunos títulos. Los niños refieren haber leído libros de María Cristina Ramos, de Roal Dahl, Los cretinos. También nombraron el libro que le había prestado al maestro el día anterior. Y, por último, mencionaron la "novela larga" que estaban leyendo: Los miserables. Registran en un cuaderno común datos del libro y del autor, como así también apreciaciones en torno al texto.

Les comento que había traído para compartir con ellos un cuento de Roal Dahl, incluido en el libro Cuentos en verso para niños perversos. Uno de los niños me dice que le gustó mucho de ese autor Los cretinos, y que no se había aguantado esperar para leerlo en clase, y que lo había continuado en su casa, hasta leerlo todo. Les pregunto qué otras historias conocían de ese escritor, y todos respondieron con un "noo0000000000000", a través del cual percibí que no querían decepcionarme. Al darme cuenta de ello, les comenté que estaba seguro que conocían muchas historias de Roal Dahl. Juan Manuel volvió a decir que no. Les pregunté si habían visto la película Matilda o Charlie y la fábrica de chocolates o la aterradora La convención de las brujas.

$\mathrm{Al}$ escuchar cada título mencionado, asentían y empezaban a sonreír. Les dije que todas esas películas, que seguro habían visto miles de millones de veces, estaban basadas en libros de Roal Dahl y que, al fin de cuentas, sabían más de las historias escritas por ese autor de lo que creían. Todos los niños participaban, a través de comentarios, tomando la palabra. Otros preferían asentir lo que el compañero expresaba.

Les leo la historia de Roal Dahl seleccionada y, enseguida, me piden que les lea otra historia. Les propongo la lectura de El árbol de lilas, de María Teresa Andruetto. Les hago una breve introducción de por qué la autora escribió esa historia, y los niños se muestran muy interesados.

Luego, el maestro saca el libro-álbum que le había prestado del armario y les propone volver a leerlo. Los niños escuchan interesados la historia, como si fuera la primera vez, mirando atentamente los dibujos. Los que están más alejados se estiran por sobre sus mesas. Apenas termina de leerles, el docente les pregunta a los niños "¿qué interpretaron?". Los niños se mantienen callados. Uno de los niños empieza a contar la historia, refiriendo la situación inicial: la de una niña sentada en la mesa con su madre. El docente dice "no", y el niño, sintiéndose abrumado, baja la cabeza.

"Vamos!", dice el docente, más como reprimenda que como invitación a participar. Así lo percibo, porque ningún otro niño se animó a intervenir en la situación. El 
maestro me mira y me pide ayuda. Me dice que no sabe qué hacer para que hablen ${ }^{42}$. En realidad, la frustración del docente en cuestión remite a que no encontró en el comentario del primer niño la respuesta por él esperada. Así que vuelve a instar la participación, pero los niños parecen resistirse a afirmar un significado válido en torno al texto, a ofrecer una síntesis o moraleja, por lo cual insisten en volver a contar la historia.

Para los niños, comprender la historia equivale a poder contarla: a apropiarse de las escenas, de las escasas palabras que hay en el texto y que, a través de los tonos grises de las ilustraciones, entremezclados con rojos y verdes, van percibiendo como angustiante.

El docente se siente nervioso y vuelve a solicitar mi intervención: me pasa el libro y me dice: "Fijate qué podés hacer"’ł3. Así que busco en el libro rápidamente y les muestro el dibujo donde aparece un personaje, que se repite en las tres escenas siguientes, pero del cual nunca se menciona quién es o por qué aparece. Se los señalo y les comento: "En el libro hay una nena y su mamá, según nos cuenta la historia. Ahora, ¿quién será este señor que aparece acá? Algunos me responden que es el padre, uno refiere que es el padrastro. Una niña me cuenta que puede ser un amigo o un tío. Les digo que es muy interesante lo que dicen. Y que, más allá de si es un papá o un padrastro o un tío (doy vuelta la página y muestro el dibujo del abrazo entre la niña y el señor), parece que es un ser querido. Un niño me responde: " $Y$ síl, si lo está abrazando". Asiento. Y agrego: "¿Y por quépiensan que este señor sólo aparece dibujado en el libro y nunca se dice quién es? Y me contesta una niña: "Porque no está, la nena se lo imagina". Y agrega un compañero, con severidad: "Está muerto. Se murió el papá de la nena".

Les comento lo interesantes que son sus comentarios, sobre todo porque las historias no siempre tienen el mismo sentido para todos los que la leen. Al finalizar la clase, uno de los niños se acerca para ofrecerme en calidad de préstamo el libro Los cretinos. El mismo niño me pide permiso para saludarme. No dudo en darle un abrazo y agradecerles a todos el lindo momento de cuentos compartido.

\section{3.}

En el recreo, Marcelo (4 $4^{\text {to }}$ grado) y "Vé" (6 $6^{\text {to }}$ grado) conversan sobre un libro, debatiendo cómo es la gente que vive en India. Marcelo se levanta del suelo y, con la espalda encorvada, finge sostener con su mano derecha una rama, la cual funciona como bastón. "Asi es la gente de India me parece", agrega. "Y después fue haciéndose así (comenta mientras se endereza lentamente), hasta llegar a abora".

"Vé" lo mira y, desinteresada, toma un libro del suelo. "Leamos este", invita a Marcelo. $\mathrm{Al}$ rato, ambos niños me llaman porque querían conversar sobre un aspecto del libro. "Vé" reprocha que las Princesas del cuento tienen nombres "muy raros". Les pido el libro y voy a la portada, mostrándoles el título, se los señalo y ellos leen: Princesas olvidadas o desconocidas ${ }^{44}$. Levanto la voz, dado que en el recreo había mucho bullicio, para comentarles que el título nos daba algunas pistas para comprender por qué resultaban extraños los nombres de las princesas. "Vé" se sobresalta y me informa:

\footnotetext{
${ }^{42}$ Normalizada por la institución escolar, la hora de lectura de literatura suele convertirse en un interrogatorio. De esta manera, se obliga a los niños a hablar respecto al sentido (único) del texto, lo cual cercena el potencial de la experiencia lectora de constituir subjetividad, ya que no se respeta el derecho de los sujetos de reservarse emociones, sensaciones, etcétera. Es decir, el derecho a ser poseedor de una dimensión subjetiva no susceptible de ser socializada.

${ }^{43}$ En las palabras del docente, pareciera que el "producto" prima por sobre el "sentido del hacer".

${ }^{44}$ Lechermeier, Philippe (2008). Princesas olvidadas o desconocidas, editorial EDELVIVES.
} 
"No me gusta que me griten". Marcelo interviene inmediatamente, para calmar a su compañera: "No, "Vé", no te asustes. No te está retando. Pasa que él habla con voz fuerte, como la seño de $2^{\text {do }}$, pero no es malo. Acordate que Esteban trabaja para los derechos de los niños ${ }^{\prime 45}$.

Interesa recuperar de este pasaje la apropiación que el niño realiza en torno al paradigma de derechos. En correlato con ello, Leiras (1994: 3) refiere que los niños tienen creencias y percepciones de lo que les corresponde en cuanto niños en la sociedad y en los espacios sociales. Y si bien su investigación en torno a las percepciones de la niñez sobre sus derechos es limitada, puesto que se restringe a un número acotado de niños, sus resultados alientan una actitud optimista en la medida en que las nuevas generaciones tienen expectativas claras acerca de lo que les corresponde como seres humanos en desarrollo.

Sin embargo, cabe referir algunas cuestiones en pos de interrogar lo expuesto por el autor mencionado:

En principio, debe considerarse que si bien la mayoría de las niñas y los niños poseen conocimiento en torno a sus derechos, existen situaciones en la que docentes y adultos en general, condicionan la posibilidad de que estos conocimientos se traduzcan en el ejercicio de esos derechos.

En segundo lugar, a modo de hipótesis, puede establecerse que la disociación entre el ámbito familiar y el ámbito escolar des-responsabiliza a los agentes escolares en su función estatuida de colaborar en la crianza y garantizar los cuidados de la niñez y des-responsabiliza a la familia de su función estatuida de colaborar en la educación escolarizada.

Una tercera cuestión permite inferir que el discurso de los derechos de la niñez suele ser utilizado para encubrir acciones contrarias a derechos, en detrimento de su valoración como herramienta para problematizar las intervenciones de los agentes escolares.

Un cuarto punto, también a modo de hipótesis, requiere situar que el punto de vista ético-político de los agentes escolares condiciona la efectivización de derechos de niñas y niños e invisibiliza demandas expresadas por estos últimos.

Conviene, a partir de estos lineamientos, reconocer que la posibilidad de ejercicio de derechos por parte de niñas y niños remite a dinámicas complejas a partir de las cuales se elaboran situaciones como "problemas" y que son disparadoras de un proceso durante el cual entran en diálogo, conflicto y negociación las categorías con las cuales pensar la infancia, la educación, la familia y la intervención profesional en el contexto escolar involucrando a profesionales, niñas y niños y sus familias, entre otros actores.

\footnotetext{
${ }^{45}$ Nota de campo, Escuela "F", La Plata, Agosto de 2012.
} 


\section{4.}

(MG-4 $\left.{ }^{\text {to }}-\mathrm{TT}\right)$ "Me gustaria conseguir el financiamiento para armar una escuela primaria $y$ secundaria en Berisso, donde puedan estudiar los descendientes de italianos. Porque en La Plata hay una, pero puede ir cualquiera. Y a veces, hasta es dificil para un descendiente de italiano conseguir un banco".

Fui a observar una clase de Prácticas del Lenguaje al aula de esta docente. La maestra me presentó a su clase y les dijo: "V amos a mostrarle a Esteban que nos portamos muy, muy bien". Y, acto seguido, los invitó a cantar una canción en italiano que les había enseñado al inicio del ciclo lectivo.

Al finalizar el canto, repartió a cada uno la fotocopia de una noticia extraída de un periódico. Y anunció: "Hoy vamos a ver conectores temporales. Los conectores temporales nos indican el TIEMPO”, explicó. Luego leyó algunos ejemplos, clasificándoles en conectores: 1) de anterioridad; 2) de simultaneidad; 3) de posterioridad.

Pregunta a sus estudiantes: "El papel que les repartí, ¿qué es?". Como ningún niño responde, agrega: " $E$ s una lectura?". Y la maestra se responde: "No, es una noticia". Nombra a una niña para que inicie la lectura, interrumpiendo en un punto para indicarle a otro estudiante que prosiga y así hasta leer todo el texto. La docente refiere en el momento de lectura de Sebastián: "Cómo se nota que dejaste de practicar! Estás leyendo mal de nuevo". Y, por lo bajo, me comenta que la mitad de los niños a su cargo se "terminaron de alfabetizar en febrero, en la instancia de recuperatorio".

Posteriormente les informa a los niños la consigna: encontrar en el artículo periodístico los conectores y clasificarlos. Otorga quince minutos para resolver la actividad. Informa luego que es tiempo de corregir.

La maestra lee la primera oración. Pregunta: “Hay algún conector abi?”. Los niños responden que no. La maestra refiere: "¿Cómo no?! Presten atención”. Y vuelve a leer la oración, resaltando con VOz más fuerte el conector que se encuentra en la frase. Cuando la docente vuelve a preguntar cuál es el conector de la primera oración, los niños repiten la palabra que ha sido pronunciada con voz más fuerte por parte de la maestra.

La maestra sigue leyendo: "La luna, AL MISMO TIEMPO, podrá verse...". Los niños responden a coro cuando la docente pregunta si en la segunda oración hay un conector: "Al mismo tiempo". En la tercera oración los niños no identifican conector alguno. La docente vuelve a incentivar en esa frase la identificación de un conector. "Recuerden que indican el tiempo". Entonces un niño lee: "A las 8.05 p.m podrá verse... 8.05”. "NO!”, exclama la docente. "Indican el tiempo, la novela que estamos leyendo está llena de esos conectores". Y lee: "PRIMERO podrá verse...", y los niños se apresuran por responder: "Primero!".

Casi finalizando la clase, un niño pregunta a la maestra: "¿Esta es la clase de lengua? Y la docente responde: "No, no es la clase de Lengua. Es la clase de Prácticas del Lenguaje". Y oigo decir al niño por lo bajo, a su compañero y fingiendo sollozar: "Las Lágrimas del lenguaje ${ }^{, 46}$.

No podemos dejar de leer el comentario final del niño como un ejercicio irónico que nos interpela, como adultos, respecto a las formas a través de las cuales mediamos entre la

\footnotetext{
${ }^{46}$ Nota de campo, Escuela "B", Berisso, Septiembre de 2011.
} 
niñez y el lenguaje. El escenario presentado sitúa una práctica de lectura, aparece, en su totalidad, estructurada por la lógica disciplinar. En este relato se evidencia, a las claras, una situación escolar donde se demuestra que las instituciones están construidas para que los sujetos piensen conforme a normas: no para que piensen (Corea citada por Pierella; 2010: 129). En tanto cada conector utilizado en el texto es reconocido por los niños a partir de la intensidad de la voz del maestro, esta intensidad (hablar más fuerte, elevar la voz) se asocia, de manera análoga, con el silbato utilizado por los docentes de Educación Física, objeto estrictamente conductista. A la vez, los niños no se adecúan necesariamente a este dispositivo: lejos de la sumisión y de la docilidad, niñas y niños ironizan, interpelan las estructuras monolíticas de poder, producen significaciones alternativas.

Estas tácticas, resistencias y fugas producidas por la niñez suelen realizarse por lo bajo, a modo de balbuceo o murmullo, solapadamente, sin que llegue a los oídos de los adultos. Y ello porque, de ser registrado por las docentes, las expresiones de niñas y niños se corresponderían con un insulto, una falta de respeto y la consecuencia sería un reto: cuando, en realidad, las enunciaciones de niñas y niños son claras evidencias de que la subjetividad infantil captura y critica la monocorde y naturalizada experiencia de mundo.

\title{
La cuestión de la procedencia: nacionalidad, pobreza y
}

\section{racialización.}

Escena 1.

\author{
23 de Abril, Día del Idioma. \\ Lugar: Sala de maestros \\ Participantes: bibliotecaria escolar, maestras de $4^{\text {to }}, 5^{\text {to }}$ y $6^{\text {to47 }}$.
}

Bibliotecaria escolar: "Chicas, acá traje la actividad que la Directora me pidió les buscara para trabajar las efemérides del Día del Idioma”. Y pone sobre la mesa un manual antiguo, lo juzgo así por sus hojas amarillas.

La propuesta de trabajo que la bibliotecaria compartía era un crucigrama que tenía en el centro la palabra IDIOMA. Las palabras que había que completar requerían el conocimiento de escritores nacionales, por lo cual se ofrecían como pistas títulos de sus obras o los nombres de pila. Algunos de estos autores eran Sarmiento, José Hernández, Esteban Echeverría, Estanislao del Campo, María Elena Walsh, entre otros.

\footnotetext{
${ }^{47}$ Nota de campo, Escuela "F", La Plata, Abril de 2012.
} 
Las maestras comentan que, teniendo tantas cosas que hacer, las efemérides son una pérdida de tiempo, y que por ello van a dar esa actividad como tarea para el hogar. "Me siento obligada a trabajar las efemérides, por eso me niego, con las cosas importantes en las que tengo que avanzar", amplía una de las docentes presentes.

Como me inquieta que la conversación no incluya, a modo de discusión, qué interesa enseñar a través de esa actividad pregunto, con prejuicio, de qué año es el manual. "De 1979", me responde la bibliotecaria. Y enseguida le pregunto a la maestra de $5^{\text {to }}$ cuántos alumnos de otros países hay en su clase.

La maestra me responde: "A mi no me importa eso, yo no presto atención a esas cosas. Hay peruanos pero son respetuosos, mi abuela también era de Perú. Tienen mucho respeto para con los maestros, valoran la educación y son muy estudiosos".

Le aclaro, a partir de su comentario, la intención de mi pregunta, aludiendo que quizás lo que no se estaba pensando era en el propósito de la actividad relacionada al Día del Idioma. Le explico que para responder al crucigrama los chicos iban a tener que recurrir a manuales y le recordé que ellas mismas, como docentes, suelen referir que las actividades de investigación son realizadas en el hogar por un número reducido de niños.

Les sugiero a las docentes pensar una actividad que se proponga explorar la diversidad lingüística, apelando a la procedencia geográfica de los referentes familiares de sus alumnos. "Muchos papás vienen de Bolivia, Perú y Paraguay me contaron ustedes".

Y la maestra de $5^{\text {to }}$ agrega: "Y también hay idiomas dentro del país, en cada provincia". "¿Cómo se llaman? ¿Sociolectos?", agrega la docente de $6^{\text {to }}$. Aprovecho el ritmo de la conversación para proponer: " $Y$ si les piden a los chicos que armen un glosario con palabras provenientes de otras lenguas, diferentes a la española?". La maestra de $5^{\text {to }}$ dice que implementará la propuesta del crucigrama y también la del glosario. El resto de las docentes expresaron que sólo trabajarán el glosario.

Dos días después, un grupo de niñas de $3^{\text {ero }}$ y $4^{\text {to }}$ grado se acercó en un recreo para enseñarme a pronunciar palabras en quechua y aymara y también su significado. Recuerdo que meses atrás una niña refería, hablando de los lugares de procedencia de sus padres, que ella sólo le podía hacer preguntas al respecto a su madre, porque su papá "se pone malo" con esos interrogantes, "no me quiere contar nada", expresó a sus compañeras.

\section{Escena 2}

1 al 7 de Octubre, Semana de la no discriminación.

Lugar: aula de $1^{\text {er }}$ grado.

Participantes: maestra a cargo, un total de 15 alumnos, observador.

La maestra reparte una fotocopia, extraída de una revista destinada a docentes del primer ciclo. En ella se lee el siguiente texto:

$$
\begin{gathered}
\text { ¡No a la discriminación! } \\
\text { La discriminación } \\
\text { es un tema de importancia. }
\end{gathered}
$$

Nos hace más humanos Elegir la tolerancia. 
Somos todos distintos,

pero iguales en dignidad.

Con respeto y justicia

conviviremos en pa\%:

Silvia Beatriz Zurdo ${ }^{48}$

La maestra realiza la lectura del texto en voz alta, invitando a los alumnos a seguir la lectura. Cuando finaliza la lectura, la maestra le pregunta a los niños: "¿Qué es ser tolerante?". Ninguno contesta. A lo que agrega, tratando de ayudar: "Tolerante... asociado a paciencia...". Los niños se remiten a repetir en voz baja alguna de las palabras que escuchan de la maestra: "Tolerante... paciencia", se les escucha susurrar a algunos. La maestra trata de dar algunos ejemplos que aporten a la conceptualización: "Por ejemplo: voy a ser tolerante con Manuel para esperarlo a que haga la tarea o si a alguien le gustó un dibujito distinto al mío, no me voy a pelear con él por eso".

La maestra se empieza a sentir frustrada ante la incapacidad de dialogar junto a los niños. Su voz se pone nerviosa, pero en ningún momento se irrita con ellos. Inmediatamente cambia de tarea: escribir cooperativamente en el pizarrón la fecha y el nombre de los compañeros ausentes. Luego, cada niño copia en su cuaderno lo registrado en el pizarrón. Fue ahí cuando la maestra vuelve a su escritorio, se sienta y me comenta lo difícil que le resulta ser docente.

Me comenta que ella se recibió de grande, a los cincuenta, y que hace cuatro años que ejerce. Me dice que en la otra escuela donde trabaja los niños asisten a aulas completamente sucias y que a nadie le preocupa que un recreo dure veinte minutos: "El otro día me peleé con la Directora. Le dije que por favor biciera algo para que el personal encargado de la limpieza sacara la basura que estaba desparramada en el aula. ¿Sabés lo que me contestó? Me dijo: 'bacéle un acta al encargado'. Yo le dije que el acta se lo iba a hacer a ella; ella es la responsable de garantizar las mejores condiciones para los chicos. Pero bueno, volviendo al tema, a veces no soy clara con los chicos, no sé cómo trabajar algunas cosas. Lo de la discriminación es una..."

Como punto de partida para reflexionar sobre las escenas narradas, nos referiremos a Hobsbawm (citado por Déloye; ibidem: 58), para considerar que el nacionalismo "inventa" culturas desprovistas de toda base étnica a fin de unificar el imaginario de las naciones; impone lenguas para reforzar su coherencia o movilidad internas y logra así asegurar la lealtad de los ciudadanos que comparten una similar concepción del mundo impuesta por el Estado y transmitida por su sistema escolar. A partir del procedimiento de invención mencionado, se

\footnotetext{
${ }^{48}$ Este texto, escrito por Silvia Beatriz Zurdo y publicado en una revista editada en Argentina, también aparece en el número 97 de la Revista española Maestr@ de primaria, publicada en el mes de noviembre de 2012 ya que el 17 de ese mes es el Día Internacional para la Tolerancia. Por ello, a diferencia de la publicación en Argentina, el título que encabeza el texto de Zurdo para la edición española es "Sí a la tolerancia".

${ }^{49}$ Nota de campo, Escuela "F", La Plata, Octubre de 2012.
} 
trazan fronteras simbólicas que establecen no sólo lo que corresponde al "ser nacional", sino que también construye "lo extranjero" como el arquetipo de lo no deseado.

El clivaje geográfico de ese "otro", proveniente de un país limítrofe, no lo hace verse como "un extraño". Por el contrario, ese "otro" enseguida queda inscripto en un entramado de significados basados en la "peligrosidad", el "atraso" (en el sentido de pautas de vida que interpelan las "formas de vida civilizadas") y el "retraso" (asociado a sus "conductas mentales" y a las dificultades en el aprendizaje, incluso de la lengua española). Es así que cualquier visión de las culturas como totalidades claramente definibles es una visión desde fuera que genera coherencia con el propósito de comprender y controlar (Benhabib; 2006: 29). Y a veces, la procedencia geográfica de los padres pesa más que el territorio donde nació el niño y su ciudadanía.

Es así que algunos agentes escolares suelen referir que un niño particular es boliviano, no porque nació en dicho país, sino porque sus padres lo son. Ello expone, a las claras, que no es la semejanza objetiva la que funda el lazo nacional, sino la percepción que tienen los actores de la frontera entre el semejante y el otro (Weber citado por Déloye; ibídem: 62). Así, el control del aparato escolar nacional se orienta no solamente a responder a las necesidades de formación de la economía moderna sino también -y quizás principalmente- a desarrollar una conciencia nacional que autorice una separación entre los ciudadanos nacionales (Déloye; ibidem: 59) y los percibidos como extranjeros, ya que la ascendencia y "la sangre" colisiona con el derecho argentino (puesto que la mayoría de las niñas y niños nacieron en Argentina, siendo sus padres los migrantes).

Ahora bien, si la construcción de un "ser nacional" obligadamente requiere de la existencia de un "otro", ¿qué sucede cuando ese "otro" necesario -y necesariamente diferentecoincide justamente con el sujeto que se debe nacionalizar?

Con el término identidades despolitizadas, Brubacker (citado por Déloye; ibídem: 73) se refiere a aquellas construcciones identitarias que pierden todo poder de discriminación, todo estatuto de barrera social legítima. A partir de ello merece ser recuperado el concepto de "raza", desde la conceptualización elaborada por Segato (2010), quien explica que dicho término remite a una realidad resultante de una selección cognitiva de rasgos que pasan a ser transformados en diacríticos para marcar grupos poblacionales y atribuirles un destino como parte de una jerarquía social.

Afirmaciones como las referidas a continuación dan cuenta de ello:

("F"-4" 
("F"-5 indirectas. No entienden los chistes".

("F"-2 ${ }^{\mathrm{do}}$-TM) "No adoptan las pautas de acá, se quedan con mucho de lo de su país".

Sobre estas afirmaciones, referidas a la nacionalidad atribuida a los alumnos y a sus prácticas, es que algunos docentes confirman que:

( $\left.4^{\text {to }}-\mathrm{TM}\right)$ "aunque la política diga que la educación es para todos, no todos van a poder ser incluidos".

El extracto de entrevista referido se implica con las reflexiones de Siede (2012), quien sostiene que uno de los problemas frecuentes en el campo educativo es la licuación de los significados. Mientras más se usan palabras como "democracia", "valores", "inclusión", "derechos humanos", cada vez van perdiendo su carácter provocador, su fuerza semántica. La escuela es para el autor, en este aspecto, una importante licuadora de sentidos, cuando no se confrontan estos términos con los problemas y las tensiones que ellos mismos denuncian. $\mathrm{O}$ en palabras de Ruiz Silva, cuando los miembros de una comunidad no hacen lo que sería necesario para revertir el orden de injusticia que a-críticamente reproducen (Ruiz Silva; 2008).

Las representaciones de los agentes escolares en torno a la posición en la estratificación social de sus alumnos y de sus referentes familiares, más las consideraciones etnocentristas que permean la lógica institucional, se juegan produciendo dos fenómenos: por un lado, el saber de los más pobres es concebido como un saber menor y, por otro lado, la diversidad es identificada como déficit lingüístico. A partir de ello se crean las condiciones para que, siguiendo a Cook-Gumperz (1998: 50), una persona no alfabetizada o alfabetizada a partir de otro fondo cultural, sea reconocida como una persona ineducable, y no simplemente una persona sin educación o educada en otro contexto, con otras pautas y valoraciones.

Se narran, a continuación, situaciones donde el atravesamiento de las variables clase y raza instituyen identidades que, contextualizadas en los escenarios escolares, nos informan sobre los vínculos entre actores, y sobre aquellas tramas representacionales que establecen restricciones a lo posible, lo decible y lo pensable.

Ricardo y Agustín son hermanos; asisten a primer y sexto año respectivamente. Ambos viven con su madre, que es analfabeta, y su papá, que realiza changas. Ambos adultos son migrantes bolivianos. Ricardo presenta "problemas de escolarización", tal como refieren su maestra de grado y la Directora del establecimiento. Ricardo, 
mientras sus compañeros completan la tarea, suele quedarse mirando un punto fijo sobre la pared. La maestra, al verlo, le recuerda que debe completar la tarea que indica el pizarrón: copiar la fecha y el nombre de los compañeros ausentes.

En el aula, los niños se sientan en grupos de a cuatro. Ricardo se sienta de espaldas al pizarrón, lo cual lo obliga a girar todo el tiempo para copiar el texto escrito, además de retener aquello que debe transcribir a su cuaderno. Le pregunto a la maestra si esa disposición de los bancos no complica a los niños que se encuentran de espaldas al pizarrón y, particularmente, a Ricardo. Me responde que esa forma de ordenar los bancos fue dispuesta por la Inspectora; y enseguida le dice a Ricardo que cambie de banco con uno de sus compañeros, para quedar frente al pizarrón.

Ricardo se encuentra en el recreo intentando abrir una lata de gaseosa. Como no puede, le solicita ayuda a su hermano Agustín. La Directora pasa por el patio y al verlos exclama: "QQué hacen con una gaseosa cuando la mamá todavía no pagó la entrada al teatro para el lunes?". Ambos niños se sobresaltan, se quedan mirando el piso y la Directora se aleja diciendo "Esto no es asî".

Agustín, por su parte, se encuentra cursando el último año de la primaria. Presenta una lectura silabeada y sus compañeros siempre se burlan cuando lee. Lo cierto es que muchos de los que se burlan de Agustín leen del mismo modo que él: sólo que leen cuando son obligados por la docente. Por su parte, Agustín se desespera cuando algún adulto propone que un alumno inicie la lectura o la continúe, y suele ofenderse si no es elegido para leer cualquier texto.

Me cuenta Agustín que escribió dos cuentos, pero cuando le recuerdo sus intenciones de mostrarme sus producciones me cuenta que las perdió. "Seguro no escribió nada", me dice su maestra a cargo cuando le comento los títulos de los cuentos que el niño me comentó que había escrito ${ }^{50}$.

Soledad asiste a cuarto grado y, pese a su lectura lenta, se desenvuelve como una "lectora competente". Sus padres, al igual que los de Ricardo y Agustín, vinieron desde Bolivia hace poco menos de diez años. A pesar del escaso material literario disponible en su hogar, se encarga de revisar todas las revistas que encuentra. En una de ellas encontró una fábula, la cual le habían solicitado como tarea para la lectura libre de los viernes.

"Qué bien que leíste Soledad", la felicitó la maestra cuando leyó para sus compañeros. "Y eso que tenía palabras difíciles", agrega la docente, refiriéndose al español de castilla. La maestra me comenta que pocos son los que cumplen buscando los textos que le son solicitados, como por ejemplo, en esta situación particular, fábulas.

Lo cierto es que son escasos los niños que cuentan con disponibilidad de textos en sus propios hogares. Asimismo, no hay estrategias desarrolladas por las familias para acceder a los textos solicitados. Ninguno de los niños son socios de bibliotecas populares, a la vez que son escasas dichas instituciones en las zonas donde viven. Suelen referir algún comedor al que asisten como un espacio donde encuentran libros.

Una situación particular con Soledad, me recordó la frase de una docente de otro establecimiento educativo:

("A"-MG-4"-TT) "Para la escuela es difícil de sostener la práctica de la lectura, porque en la escuela se lee muy poco en comparación con que habría que leer afuera. Pero yo creo que si los padres

\footnotetext{
${ }^{50}$ Nota de campo, Escuela "F", La Plata, Mayo de 2012.
} 
no acompañaran a sus hijos, los chicos igual tendrían interés por leer. Cuando los llevás a la biblioteca, salen deslumbrados".

Soledad me pidió ir a su aula, a buscar lapicera y papel. Nos encontrábamos en la biblioteca escolar, unos cuarenta niños de todos los grados. Era un viernes de paro, algunos niños habían asistido y una maestra que no adhirió a la medida de fuerza se hizo cargo del grupo.

La Directora me propuso llevar a los niños a la biblioteca escolar para la hora de lectura libre. Acordé; entonces les anunció a los niños que "sin ningún útil se organicen para ir a la biblioteca". Cuando la Directora me propuso concurrir a la biblioteca supuse que, tácitamente, coordinaríamos la actividad junto a la maestra de grado presente, pero no.

Al rato me encontré junto a cuarenta niños. Me recriminé después no haberla convocado pues en ese momento tampoco contaba con la información respecto a cómo la Directora le había planteado a ella la propuesta de trabajo. Quizás también me desalentó indagar en esta cuestión puesto que concebí, con poca indulgencia, que la maestra de grado se había desentendido y desatendido de la situación, de un modo u otro.

De todos modos, me remito a esta situación porque, una vez que organicé a los niños en grupos reducidos y mixtos para compartir unos libros, Soledad se acerca pidiéndome, tal como explicité, ir a su aula por papel y lápiz. Recordé a la Directora comunicando la asistencia a biblioteca sin útiles. Igual accedí al pedido de Soledad. Sabiendo que venía de un hogar sin libros y que su escueta fuente literaria la constituían revistas infantiles que le pedía a una prima de su misma edad, la situación en la biblioteca escolar era una oportunidad para apropiarse materialmente de la literatura.

Soledad, al volver de su aula, se ubicó por fuera de su grupo y de rodillas, inclinada sobre el libro, acomodó una hoja en blanco y empezó a copiar. Se puso de pie al rato, dobló la hoja cuatro veces y, una vez reducido el tamaño del papel, lo guardó en el bolsillo de su guardapolvo. Cuando la niña reparó que la estaba observando, se acercó para decirme: "Así lo puedo leer un montón de veces en mi casa"".

Recupero esta situación puesto que las acciones de Soledad nos inscriben en la importancia de conocer la diversidad socio-cultural, asida a la dimensión económica y racial, para precisar descriptiva y argumentativamente, el umbral entre los procesos de inclusión y exclusión que ocurren en la educación formal (Segato; 1999).

En este sentido, Soledad desarrolla tácticas en un contexto donde el acceso a la literatura se encuentra condicionado por las representaciones de las docentes. Soledad se incluye en una comunidad de lectores en la cual los adultos, en su mayoría, conciben discursivamente la importancia de la lectura pero son escasas las acciones que atienden a los gustos singulares de las niñas y niños. A su vez, las condiciones socio-económicas modulan la accesibilidad a los libros. También, la población migrante preserva un acerbo literario

\footnotetext{
${ }^{51}$ Nota de campo, Escuela “F”, La Plata, Noviembre de 2012.
} 
mediatizado por la oralidad, supuesto no tenido en cuenta por las docentes en las situaciones áulicas.

Asimismo, desde el posicionamiento de los adultos, se explicita la exigencia de leer por fuera de la escuela, pero poco contribuyen a garantizar el usufructo de libros. Recuerdo a Soledad leyendo para sus compañeros la fábula recortada de una revista infantil, ajada; y los libros bajo llave en un armario de la biblioteca escolar, sólo disponibles para el préstamo domiciliario aquellos que la bibliotecaria considera acordes a los niños pobres: libros cuya encuadernación es deplorable, con páginas faltantes y/o sin tapas, generalmente libros escolares, donde las poesías son a la bandera, a la Patria, a la familia: remanentes de una producción editorial centrada en la institución educativa y en la formación cívica de la población destinataria.

Lucía se acerca despacio durante el recreo a observar los libros que desparramé en el piso del Salón de Usos Múltiples de la escuela, acompañada por una de sus amigas. Le pregunto si hay algún libro que quiera mirar con tranquilidad. Me señala uno, se lo acerco. También le ofrezco una silla, por si no quiere sentarse en el piso como el resto de sus compañeros. Acepta. Recorre el libro con la vista, centrándose en las ilustraciones.

En el recreo siguiente Lucía se acerca nuevamente al lugar donde me encontraba con los libros, me extiende un billete de dos pesos. Me pregunta si con ese dinero puede comprar el libro que leyó. Le explico que los libros no están a la venta, que son para compartir en ese espacio y que los libros ni siquiera son míos, que los traigo de una biblioteca popular llamada Pestalozzi.

Lucía, al rato, discute con una compañera. La compañera, que cursa con ella el tercer grado, le recrimina que antes Lucía la peleaba. A lo que esta última responde: "Y sí, si eras una negrita boliviana”. Interrumpo la discusión y le cuestiono a Lucía la ofensa, que se esté burlando de su compañera por el lugar donde nació. Intenta justificarse, la escucho, pero no completa su justificación.

Conversando con su maestra de grado me comenta que en otra oportunidad donde tuvo que intervenir porque Lucía le decía boliviana a otra de sus compañeras, la niña respondió: "Ya sé, ya sé. Si yo también soy una negrita de porquería".

En una ocasión me encontré en un cambio de turno con Lucía, su madre y su tía, las cuales aguardaban un remís porque llovía. La niña me saludó y me presentó ante su familia. Su mamá me comenta que escuchaba a Lucía y a su primo, que también asiste a la misma institución, nombrar a un Esteban, pero que no entendían si era maestro, profesor o qué. Mientras explicaba a la madre y a la tía de Lucía mi presencia en la escuela, la niña expresa que a ella le gusta leer. Inmediatamente la madre agrega: "¿Qué decís? Si vos no sabés leer"”2.

Me remito a esta situación porque muestra con elocuencia cómo los adultos nos centramos en el déficit. Lucía no sabe leer desde un parámetro que separa binariamente: lee

\footnotetext{
52 Nota de campo, Escuela "F”, La Plata, Noviembre de 2012.
} 
bien-lee mal, sabe leer-no sabe leer. Sin embargo, si la lectura fuera entendida como proceso y no como producto, los adultos (docentes, pero también familiares) podríamos apoyar a Lucía en su formación como lectora, celebrando que se acerca al rincón de lectura durante los recreos, que se propuso para actuar en una obra el día de la Maratón de Lectura, asumiendo el papel principal, entre otras actitudes favorables.

Pero, retornando a la variable raza, recordemos la justificación de Lucía cuando se le señala su actitud discriminadora. "Si yo también soy una negrita de porquería". Me interesa recuperar este fragmento del discurso de la niña puesto que expresa la subjetivación de una marca producida por lo que Quijano (citado por Segato; 2010) reconoce como la biologización de la cultura. El peso de la raza en aquellos pueblos y sujetos expoliados, lejos de otorgar cierto "sentido de unidad" por compartir similares características étnicas (de hecho Lucía tiene una abuela boliviana) opera reproduciendo, nietzschezeanamente, que el lenguaje le pertenece a los amos (Nietzsche citado por Feinmann; ibidem: 211).

A partir de las observaciones áulicas recuperadas, fue posible construir datos cualitativos en pos de argumentar sobre la identidad racial y económica como identidades que anticipan y definen la posiciones, siempre relativas (Segato; 2010), de los alumnos en el espacio escolar. Las instituciones escolares producen "problemas" previsibles a partir de lo que se supone son los sujetos pobres, extranjeros (de países limítrofes) o los percibidos como extranjeros. Estas construcciones, también, son mantenidas en tanto son útiles: permiten a las docentes delegar la responsabilidad a las niñas y a los niños y a sus familias en tanto los "problemas" que se presentan en el aula preexisten a este dispositivo, invisibilizando que, en todo caso, lo que se juega en ese escenario es la repetición de lo ya sabido, de un prejuicio.

\section{Notas sobre una construcción singular de subalternidad en espacios escolares: niña abyecta-niña monstruo.}

A cantar dulce y a morirse luego 
eso hiciste vos, eso yo.

Por eso te hablo, por eso me confío a una niña monstruo.

Alejandra Pizarnik, Para Janis Joplin ${ }^{53}$

Si me pregunto o si alguien me pregunta: ¿puede hablar el subalterno? (Spivak; ibidem), puedo responder por "Si" o por "No", y no ahondar en la cuestión, sin sentir culpa por clausurar la motivación reflexiva que este interrogante significa para, al menos, gran parte de los académicos. Pero, en este caso, responder a la pregunta señalada -en términos heiddegerianos-, implicará "posicionarse ante la cosa" y más cuando se ha aprendido que las preguntas que se responden por "Si" o por "No", generalmente, son malas preguntas.

Se propone en este apartado analizar la construcción de sujetos subalternos en instituciones escolares poniendo en tensión las prácticas de los agentes escolares con los discursos y prácticas de aquellos sujetos en su condición de niñas y niños. En este sentido, interesa analizar la construcción de lo subalterno como expresión de la experiencia y la condición subjetiva del subordinado, determinada por una relación de dominación -en términos gramscianos, de hegemonía- (Modonesi; 2010). Por ello, se problematiza lo subalterno atendiendo a lo que ello tiene de construcción, de producción representacional, y no porque subalternidad exprese una realidad empírica per sé.

A través de notas que condensan el trabajo etnográfico se problematiza la construcción singular de subalternidad en torno a un sujeto en su condición de niña. La información recabada fue producida a partir de conversaciones con sus referentes escolares y otros actores, y observaciones en situaciones áulicas y durante los recreos. Se explicitan fragmentos referidos a diálogos con la niña de referencia, pero preservando su identidad.

Se propone, de este modo, un análisis en torno a las formas de sociabilidad escolar a partir de la caracterización de entramados relacionales divergentes, no susceptibles de agotarse y cristalizarse en los marcos normativos que regulan su funcionamiento y en las políticas del sector que los atraviesan. La apuesta reflexiva supone reconocer y problematizar que la inscripción en el nivel macrológico (el de la Política Educativa, incluyendo los principios

\footnotetext{
${ }^{53}$ Pizarnik, Alejandra (2000). Poesía completa. Barcelona: Lumen.
} 
universales que motivan su legislación) no puede servir de parámetro para la textura micrológica del poder (el nivel de las prácticas educativas).

Si la mirada nostálgica en torno a las instituciones escolares inhibe la exploración y visibilización de nuevas realidades sociales, ¿la pervivencia de qué elementos cristalizados en las prácticas de los agentes escolares sostiene la fijeza de la tradición, la frondosa oscuridad de lo instituido? En este sentido, asumiendo lo instituido como arbitrariedad inmanente a la dinámica histórica de las relaciones sociales, ¿qué formas de sociabilidad y qué tipo de legalidades integran a sujetos niñas-niños a la cultura, reduciendo esta integración a una “problemática del orden”? Y por último, ¿qué tipo de afectos posibilitan trascender la mera sobrevivencia del cuerpo para acompañar la construcción de un proyecto de vida?

\section{Niña abyecta-niña monstruo.}

Llegué por primera vez a la escuela cuando las niñas y los niños aguardaban en pequeños grupos el sonido del timbre para formar filas y saludar a la bandera. Esperé sentado en un banco cerca de la puerta de entrada que le informaran a la directora mi llegada. A "Vé" la vi aproximarse en ese momento de mora, saltando por el pasillo izquierdo del establecimiento sobre una rayuela imaginaria. Cuando me vio, se acercó y me dijo: - "Yo a vos no te conozco"-. - "Voy a venir seguido"-, le respondí. Y agregué: - "Por abi tenemos suerte de conocernos"-. Y ella siguió saltando sobre su rayuela imaginaria, infinita, que continuaba extendiéndose por el ala derecha de la institución.

En los días siguientes, "Vé" siempre se acercó con curiosidad a los libros y a los cuentos que llevaba para compartir con ellos durante el recreo. Entre el bullicioso insoportable de niños corriendo, de niños gritando, de niños golpeándose, junto a un grupo de niños -dentro del cual se encontraba "Vé"-, movidos por la fuerza de su propio deseo -, formábamos ronda en el piso de la galería: para leernos libros breves, para contarnos cuentos $y$, ante todo, para conversar. A veces no éramos menos bulliciosos que los niños que corrían por el patio, gritando, a veces peleándose. De hecho, en el "círculo de lectores y libros" que espontáneamente conformamos, las disputas y empujones por los libros codiciados se generaban con frecuencia, e incluso había burlas por las dificultades en la lectura de algunas niñas y niños: - "Mirá profe que él lee mal"-. O por el lugar de procedencia: - "Ella es bolita y fea"-.

Un día "Vé" me muestra la portada de un libro de leyendas del noroeste argentino y señalando el continente americano me pregunta: - “Dónde queda India acá”?-. Le respondo que en la portada está el continente americano dibujado, que India está en otro continente. Me interrumpe. - "Yo quiero ir a India, saber cómo viven, qué comen, qué hacen. Quiero vivir ahi”'-. Demanda que le consiga un pasaje, en barco. Le comento que sólo puedo compensarla buscando en alguna biblioteca libros y cuentos sobre India. Asiente.

En otros recreos, cuando no organizábamos ronda de lectura por motivos diversos, "Vé" caminaba sola por los pasillos y el patio, intentando iniciar diálogo con alguna de sus compañeras, las cuales la miraban con desdén y se reían. "Vé" no recibía de 
sus compañeras ninguna palabra como respuesta; tan sólo los gestos característicos del rechazo.

Por ello, "Vé" se acercaba a otras niñas. "Vé", con once años, buscaba entablar amistad con niñas más pequeñas, y si bien algunas de ellas reproducían las nomenclaturas con la que los chicos más grandes le otorgaban existencia: "Es tonta", "Es una tarada", algunas niñas le correspondían el abrazo cuando "Vé" lo demandaba, después de haber girado como un satélite sobre los grupos de compañeras de su edad, las cuales le devolvían la espalda ante el pedido explícito de entablar amistad.

Un día mencioné su nombre en la sala de maestros. Dije: - "Vé..."- no más, y obtuve las siguientes respuestas: - "Vé, yo la tuve en cuarto... es especial"-, - "Sí, tiene como un retraso esa nena..."-, agregó otra maestra. Y la última maestra que allí se encontraba culminó: - "Ah, esa nena..."-.

Al día siguiente, cuando me crucé con "Vé" en un recreo me dijo: -"Yo a vos no te conozco"-. - "Seguro porque nunca me viste sin barba, como boy"-. - "No, no es por eso que no te conozco. Es porque boy no andás con libros por el recreo"-, explicó.

En el recreo siguiente, ubicado en el patio junto a una maestra, observamos que Marcos, compañero de grado de "Vé", le pega una patada y le dice "pelotuda, sos fea", riéndose. "Vé" lanza un golpe con su mano cerrada, al aire: más para descargarse que para devolver la ofensa. La maestra, sin desplazarse hacia la situación, grita: "¡Marcos!, ¿qué hacés? ¡No pelees!”-, y dirigiéndose a mí comenta: - "Pobre Vé, la toman por tonta".

Unos días después presencio una situación similar: "Vé" esquivando a dos compañeros que la señalaban y se reían, al mismo tiempo que uno se abalanzaba sobre ella buscando tironear su pelo. Me acerco, urgente, y le hablo a los chicos: - "Yo no soy maestro, y mucho menos vengo a retarlos, pero lo que no puedo permitir es que se metan con el cuerpo de otra persona"-. Comprendieron enseguida el límite y pidieron disculpas, pero no a ella. A ella dejaron de mirarla. Los chicos se fueron y le pregunté a "Vé" cómo estaba.

Durante los recreos de los días siguientes "Vé" se acercó para conversar. A continuación, algunas extracciones de las varias conversaciones realizadas durante el periodo de diez minutos que separa el trabajo en el aula:

- "No quiero crecer, pero tampoco quiero quedarme así. Todo es terrible (...).Crecer es malo (...).

Lo actual, enuncia García Canal (2006), no es eso que somos y que decimos, no es nuestro presente en sentido estricto, sino más bien eso que vamos siendo y que aún no podemos enunciar. Hiato en la existencia, lugar imaginario pleno de revelaciones, dramática (in)conciencia de que crecer constituye una arbitrariedad. Ir en contra de lo inevitable es desear arribar a un no-lugar, espacio estéril donde el pathos es vivido como tedio o como fatalidad. Por ello, "Vé" habita la tensión y, parafraseando a Lacan, se piensa donde no es.

- "Yo soñé que le pegaba a todos los chicos que me molestan, que les daba patadas y le rompía a todos la cabeza (...). Reventaba todo"-. 
El relato de "Vé" se enlaza con las reflexiones de García Canal (2003), para enunciar con elocuencia que la imaginación, cuya condición de posibilidad primera es el sueño, es del orden de la solución y no de la tarea; de la felicidad y la desgracia y no del deber y de la virtud (García Canal; ibídem). Ni la moral ni la ética invaden el profuso espacio del sueño y de la imaginación; sólo explicitación de un pathos que establece la trayectoria de un camino que se recorre como predestinación: el de cierto escenario de destrucción.

- ¿Vos sabias que yo no conozco a mi papá? ¿No te lo dijo ninguna señorita? Yo se lo conté a algunas (...). No, no me dijeron nada. Cuando pregunto en mi casa que lo quiero conocer, mi abuela se enoja. A veces me pega"-.

La transgresión, en este fragmento, explicita la toma de posición de un sujeto ante una dimensión que atañe a su existencia, a su humana condición: conocer sus orígenes. Transgresión que, permitiendo el paso de las energías que bullen más allá de todo exterior, quiebra y desgarra sentidos, rompiendo la monotonía de sus certezas enunciadas (García Canal; 2003).

Si para Nietzsche (citado por Feinmann; ibidem) el lenguaje le pertenece a los Señores, la pregunta por los orígenes trastoca toda representación del sujeto, en su condición de niña, como subalterno. Apropiación de las palabras para, a sabiendas de las sanciones y el castigo, demandar los elementos esenciales para la constitución del Yo. Resistencia limitada por la ausencia de otros adultos que, en términos de una noción de autoridad basada en sus funciones, quiebren la repetición y reproducción de la estructura asimétrica dominante (García Canal; 2005), limitando la realidad de poder impuesta y que condiciona su construcción identitaria.

- "Mi mamá lee de todo. Misterio (...). Mamá me lee y a mí me dan ganas de leer. Me compró dos libros y un juguete (...). Mi mamá tiene una voz real porque cuando me lee es real, porque hace las voces de los personajes y son tan iguales las voces que son reales los personajes"-.

En este pasaje, la voz de la madre a través de la narración se bifurca y corporiza en un haz de muchos Yoes (Hesse; 2005). La voz materna se materializa en "otros" que, en un pasaje que va de los personajes a las personificaciones, inscribe a la niña en el espacio de la cultura. El discurso materno hilvana una multiplicidad de voces dando una entidad a lo socialanónimo. 
Percepciones, afectos y efectos que configuran la trama subjetiva del infante; es decir, las condiciones que confirman el nacimiento de un sujeto, que de manera diversificada -a veces desigual-, ejercerá la potencia del lenguaje. García Canal (ibídem) refiere que la palabra otorga posibilidad de existencia social, de ingreso en la vida temporal del lenguaje que excede los propósitos de dicho nombramiento. En ese momento se produce un acto realizativo, algo sucede, algo acontece: el sujeto existe, ha ingresado en el orden de la cultura y en la vida del lenguaje.

Estar hechos de palabras, a través de un lenguaje heredado de unos extraños de los cuales la madre es mediación: a través de la voz materna, el mundo se erige ante los ojos de la niña como realidad. En la posibilidad de habitar ese mundo confiado como obvio y natural se halla, paradójicamente, la clave para su deconstrucción. Pero se requerirá de tiempo y espacio, puesto que exiliarse de lo instituido implica variadas resistencias, ya que con la caída de las certezas parentales acompañadas de la idealización de los adultos, el niño emprende un camino sin retorno; es el camino que deberá recorrer solo, con pensamientos que tienden a ser cada vez más originales, más propios (DDGCyE; 2001).

Dicha empresa por sí misma compleja, se revela más complicada aún si la subjetividad del niño no encuentra asidero en otras instituciones que acompañen sus inquietudes y sostengan sus preguntas. Y más, cuando las intervenciones de otros adultos, como por ejemplo los agentes escolares, no contribuyen al cambio en la fijeza de la tradición (Spivak; ibídem), otorgando relevancia a la presencia de un sujeto-niña pero que crece y cuyo crecimiento se encuentra íntimamente relacionado con su potencia para interpelar mandatos, silencios e, incluso, silenciamientos.

En varios recreos "Vé" me encontraba y, disimulada, se ubicaba detrás mío, siguiendo mis pasos. Yo asumía el juego, con la naturalidad de quien lleva detrás de sí a su propia sombra. Luego de un rato de silenciosa persecución y ocultamiento salía detrás de mí con un rugido feroz, para luego preguntarme si me había asustado. "Cómo no te asusté si soy un monstruo?". Solía contestarle que no, que no me asustaba; no para truncar su juego, sino pensando que era conveniente no reproducir en esa situación las etiquetas de injuria atribuidas a ella por sus propios compañeros y que la confinaban al lugar de "fea", "retrasada" y que, supuse, ella sintetizaba al llamarse a sí misma "monstruo".

Encuentro en el fragmento explicitado una intervención desatinada, configurada por un marco que inhibe, en la mirada del investigador, conocer en la transfiguración monstruosa de la niña un espacio de resistencia. En palabras de García Canal (2005), al preguntar si me asustaba, la niña intentaba "medir" la realización de un acto de ejercicio "irónico" de 
soberanía, que otorga al nombre una fuerza-otra que transforma en fuerza política de oposición, de lucha, y aun, en forma de vida al aceptar que su nombre es la injuria.

Asumir los ropajes de la abyección inviste a la niña en un territorio imaginario de poder, puesto que es en la medida en que el discurso es común que este puede convertirse, a la vez, en lugar y en instrumento de enfrentamiento (García Canal; 2006). Lo que equivale a decir: "reivindico mi derecho a ser un monstruo", 54 .

La última vez que vi a "Vé" estábamos todos en el patio, esperando el momento de izamiento de la bandera. "Vé", que ya estaba formada en la fila, ve pasar a su maestra y le dice: - "Ay seño!, usted siempre tan hermosa”-. La maestra exclama: - “Ay!”-, y atónita tarda en agregar: - "Muchas gracias "V $e$ "-.

\section{Sumario del capítulo}

\section{Notas (casi) finales, líneas pendientes: aprendizajes.}

Este capítulo intenta situarse en una perspectiva analítica tendiente a incluir, tal como lo señala Milstein, el discurso de niñas y niños en aquellos que los investigadores y académicos definen como "perspectiva de actor" (Milstein; 2009). Para la autora mencionada, se narran situaciones en las que están involucrados niñas y niños, se describen formas de buen y mal trato, se apela a su protección y resguardo, se vela por su cuidado, etcétera; pero sus historias y vivencias narradas, sus percepciones e interpretaciones no se consideran legítimas.

A partir de las interacciones, mediatizadas por cuentos y poesías, las niñas y los niños comenzaron a explicitar su propia historia, su propio cotidiano; a la vez que enunciaron demandas e intereses. E, incluso, interpelaron la dinámica institucional educativa, denunciando los trazos injustos que impedían el usufructo de determinados espacios o recursos. Así, en tanto investigador, me fue prestada una construcción de una lógica escolar particular semantizada por el discurso de niñas y niños.

A lo largo del trabajo de campo, me crucé con docentes que consideraban al niño desde sus carencias. "Todos estos chicos son buérfanos, de una u otra forma"," explicaba una Directora cuando le pregunté por qué no se abordaba la situación de una niña que, en varias ocasiones, planteaba el deseo de conocer la identidad de su padre. Desde la consideración del niñocarente, del niño-huérfano, no se problematiza la potencialidad de la educación (y de prácticas

\footnotetext{
${ }^{54}$ Shock, Susy. Enlace web http://www.youtube.com/watch?v=udup-LFqnXI

${ }^{55}$ Nota de campo, La Plata, Escuela F, Octubre de 2012.
} 
estratégicas paralelas) que aporten a la transformación de las condiciones de existencia de éstos.

Por el contrario, la figura del niño-huérfano actúa, simbólicamente, legitimando la renuncia a toda intervención por parte de los profesionales (docentes, trabajadores sociales, psicólogos, entre otros), al concebir como irreparable la situación problemática soportada por un niño o niña. Estas conceptualizaciones naturalizadas en torno a la niñez y a las formas particulares de inscripción en el entramado social determinan los límites de la acción, en tanto son motivadas por intervenciones sustentadas en carencias de orden material, y no sobre la base de problemas relacionales y/o representacionales que producen conflictos (Aquín; 1996).

Subyace en la definición de intervención presentada, una búsqueda de legitimación supeditada al principio democrático; es decir, a la invención de palabras mediante las cuales aquellos que no cuentan se hacen contar y empañan así el ordenado reparto de palabra y mudez que hace, en este caso, de la comunidad escolar una totalidad orgánica (Rancière; 2011: 68). Y ello porque el orden de la representación, al ser puesto en cuestión por un marco teórico pertinente, altera el registro de lo decible y de lo visible, en pos de la construcción de otros sentidos, los cuales revelan dimensiones otrora excluidas de la percepción de los actores.

Inscriptos en espacios socio-geográficos caracterizados por la violencia estructural - "en mi barrio cierran todos las puertas porque te pueden robar", "bay gente en mi barrio que te molesta", "estoy mal porque a un amigo le pegaron un tiro en la panza el sábado"- y, además, resistiendo a la temprana inserción al mundo del trabajo infantil como sólo un niño puede hacerlo, es decir, "jugando" "los fines de semana limpio tierra y junto vasos en el local de mi tía. Dos cosas que me gustan: trabajar y jugar, sábados y domingos”- niñas y niños son, también, hacedores del mundo: no sólo mera transición a la adultez (Chaves; 2005).

Las intervenciones de los referentes adultos de la comunidad educativa suelen tender a la institucionalización y el disciplinamiento, lo que a las claras -parafraseando a Foucault-, implica poner atención a la constitución del sujeto colonizador (Spivak; ibídem). Así, son escasas las prácticas de maestras de grado y docentes que atiendan a la diversidad como norma, en detrimento de aquellas prácticas de colegas que, fiel al legado de Procusto, cercenan "lo diferente" que configura la historia de niñas y niños singulares, con el objetivo de homogeneizar.

Por otro lado, el lenguaje al que apelan los docentes para nombrar las relaciones que se escenifican en la institución se corresponden con modelos mediáticos, propios de una política semántica de moda. Así, las situaciones de violencia entre los niños, tal como la situación de "Vé" se ocultan a través de la palabra bullying, como un problema "entre niños", 
invisibilizando una ausencia. Es decir, des-responsabilizando a los adultos de ejercer su autoridad, en términos de prácticas de cuidado, allí donde la injuria y el abuso se materializan.

Interesan los aportes de Spivak (ibídem) como insumo para interpelar las prácticas de los agentes escolares cuando enfáticamente priorizan el producto por sobre el acto de producir. Ello supone reconocer que las intervenciones no construyen cosas ni sujetos, sino tipos particulares de relaciones al interior de las cuales sujetos singulares son reconocidos desde los registros lingüísticos cristalizados por los criterios de normalidad y la desigualdad.

No pretender "acceder”, “conocer”, "identificar” las prácticas discursivas de la niñez, como si existiera una vía única y unívoca legítima: la del adulto, la del agente educativo, la del investigador. Por el contrario, y en contra de la premisa marxiana que dicta "no hay que contemplar sino transformar" se propone, a partir de este recorrido analítico, contemplar el universo producido por las niñas y los niños, parafraseando a Baricco (2012), mirando durante mucho tiempo. Hasta ver en ellos la bistoria que son. 



\section{Síntesis final.}

A partir de las coordenadas trazadas en el presente trabajo de tesis, el problema de la accesibilidad a la lectura literaria de niñas y niños a partir de las prácticas docentes permitió conocer que la apropiación de herramientas que favorecen la constitución de sujetos lectores requiere identificar las relaciones de poder que estructuran el vínculo entre los sujetos que integran una comunidad determinada.

En este sentido, hablar de los procesos de constitución de sujetos lectores, asidos al análisis de condiciones materiales y simbólicas particularizadas en establecimientos educativos públicos, complejiza el análisis en torno a la accesibilidad a la lectura literaria atendiendo a la noción de "poder" desde un doble dimensionamiento:

Por un lado, el "poder" como "competencia lectora", como habilidad, en el sentido de acceder y poner en ejercicio ciertas herramientas que permitan a un sujeto posicionarse como lector, esto es: apropiarse de la cultura escrita, conociendo su importancia en la comunidad que habita, a partir del aprendizaje de los mecanismos y procedimientos que favorecen el desarrollo lector.

Por otro lado, el "poder" como autorización; esto es: cierto espacio simbólico al interior del cual un sujeto, en este caso niña o niño, pueda reconocerse como destinatario de textos literarios y que, además, reconozca que practicar el lenguaje es condición para aparecer públicamente, demandar reconocimiento y bregar por instalar como legítimas las propias necesidades, intereses y deseos. Aunque no siempre la asimetría que se instala con los adultos sea planteada en términos de funciones de cuidados, ya que con frecuencia prima una noción de autoridad ejercida por los adultos basada en el ejercicio de poder adulto y no en las funciones que, en tanto tales, debemos asumir en pos de proteger a niñas y niños de situaciones de privación y vulnerabilidad (Bleichmar; 2006).

La constitución del niño como lector, con gustos literarios autónomos, es una figura significada socialmente a partir de las directrices de la política pública en materia de promoción de derechos culturales, siendo la escuela el dispositivo por excelencia -aunque no el único- para favorecer la concreción del encuentro de niñas y niños con la literatura y los libros. Ello supone historizar las formas a partir de las cuales la literatura y los libros han sido incluidos en el espacio-tiempo escolar y también recuperar cómo los propios agentes escolares, apelando a sus recorridos formativos y a su propia creatividad, han favorecido nuevos sentidos en torno a los textos literarios y a su uso y funcionalidad en el espacio áulico. 
Se sistematizaron representaciones que motivarían la inscripción de textos literarios en las situaciones áulicas, permitiendo esbozar los posibles usos que las docentes le otorgan al lenguaje poético. Estas tipificaciones interesan en tanto subyacen en ellas concepciones en torno a la alfabetización.

La primera supone que la función e importancia de los textos literarios radica en su utilidad como dispositivo para vehiculizar objetivos pedagógicos y/o moralizantes.

La segunda supone la realización de prácticas de lectura literaria sin centrarse en las funciones del lenguaje poético y únicamente como instancia inaugural para luego enfatizar la acumulación sumaria de conocimientos -nombres de autores o títulos de libros, cuando mucho-, perspectiva que es definida como "enciclopedista" pero que nunca interviene en la constitución de un conocimiento que conduzca a elegir (contenido, estilo, temática del libro). Estos conocimientos no se traducen en la apertura a nuevos horizontes literarios y en la creación de un hábito lector (Bahloul; 2002: 57).

La tercera supone la realización de prácticas de lectura literaria con el objetivo de evaluar la comprensión lectora de niñas y niños atribuyéndole al texto literario un sentido único y unívoco. Esta práctica no presentaría diferencias con aquellos textos específicamente de estudio en tanto que es en el retorno al mismo texto donde se verifica la validez o no de la interpretación. En otros términos, esta hipótesis podría plantearse sosteniendo que, a través de prácticas escolares, los adultos "vigilan el mundo de la percepción de los niños" (Benjamin; 1989: 28).

La cuarta se distancia de aquellas perspectivas que encuentran en la literatura una herramienta para la transmisión de mensajes y modelos al concebir la función del lenguaje poético como una forma de intervención en el reparto de lo sensible que define al mundo que habitamos (Rancière; 2010: 20). Desde este posicionamiento, la relación docente-alumnos se reconfigura en un proceso de construcción de sentido en torno al texto literario que exige que ambas partes de la relación se constituyan en sujetos lectores.

A partir de ello, emergen dos dimensiones que concretizan una modalidad particular de acceso a la lectura literaria: por un lado, reconoce que la función del lenguaje poético se halla sujeta a la "plurisignificatividad" que deviene del encuentro entre texto literario y una comunidad de lectores y, por otro lado, redefine el sentido escolarizante de las prácticas de lectura literaria al concebirlas como un "hecho total" en el que intervienen diferentes niveles de formulación del capital y del medio cultural de los individuos (Bahloul; ibídem:12).

Por otro lado, a lo largo del proceso de investigación se identificó que la infancia, en tanto producto de un relato adulto (Larrosa: 2000; Agamben: 2007; de Lajonquiere; ibídem), 
conlleva a desconocer o invisibilizar las dimensiones sociales e institucionales de los discursos y prácticas de niñas y niños, negando su capacidad de agencia reflexiva y contribuyendo a la naturalización de sus condiciones de vulnerabilidad (Reguillo, 2004). Desde esta consideración es que resultó significativo articular el proyecto de investigación, por un lado, con aquellos estudios sobre la infancia producidos en el marco de la sociología y la antropología de la niñez y, por otro lado, con la construcción social de la infancia a partir de las metodologías que legitiman la perspectiva de niñas y niños como actores (Milstein: 2008; Sawaya: 2008; Di Leo: 2009).

En lo que respecta a la vinculación de la niñez con el lenguaje literario, queda asentado que la figura del docente como mediador es clave para que niñas y niños construyan un sentido en torno a lo poético que se distancie de aquellas significaciones que presentan a los libros y a la literatura como objetos "de lujo" y a la lectura literaria como una práctica ociosa y/o elitista, patrimonio exclusivo de quienes tienen garantizadas de antemano la satisfacción de sus necesidades básicas. Negando, desde estos posicionamientos, la importancia de la literatura como necesidad básica y derecho inalienable, a la vez que invisibilizando, desde los marcos cotidianos, la importancia de reivindicar los libros, la lectura y la literatura como patrimonio común de todas y todos.

En cuanto a los núcleos duros y pervivencias de una lectura escolarizante (lo que equivale a decir: moralizante, instructiva e instrumental) se evidenció, a través de las notas y registros de campo, la continuidad de prácticas docentes que proponen: 1) una lectura más asida al interrogatorio que al juego y al disfrute, 2) la internalización de una serie de reglamentos-normas de comportamiento en detrimento de la apropiación de hábitos lectores y 3) la permanencia en una forma de silencio al momento de la lectura, más cercana al silenciamiento, y que pareciera desterrar el diálogo como posibilidad y consecuencia de todo proceso de lectura socialmente compartido.

Asimismo, se demostró que coexisten prácticas alternativas cuando no contrarias a las lógicas anteriormente expuestas. Estas prácticas, alternativas y/o contrarias a la forma tradicional y escolarizada de acercar a la niñez al lenguaje poético, se erigen sobre la recuperación de la memoria afectiva que permitió a las docentes, durante su niñez, acceder a los libros, la lectura y la literatura en el marco familiar y comunitario. Y, también, a partir de pensar sus prácticas desde representaciones de niñas y niños como sujetos portadores de una amplia capacidad para semantizar el mundo: motivo por el cual ejercen una escucha cuidadosa de los discursos que la niñez produce acerca del cotidiano institucional y de sus necesidadesposibilidades de transformación. 
En este sentido, indagar en torno a las prácticas generadas entre docentes, niñas y niños en relación al acceso a la lectura literaria, permitió abocarnos al campo de las infancias, colaborando en la constitución de un análisis de la posición de niñas y niños en la estructura de las sociedades (en este caso, escolares) y en cómo su acción social no siempre es visible en dichos marcos sociales (Dubet y Martuccelli: 1998; Gaitán Muñoz: 2006; Pavez Soto: 2012). También se puso en cuestión la noción de una socialización unidireccional sustentada en la figura de un adulto experto (Casas, 2006; Salas Cerón: 2010).

Clivajes tales como clase social y nacionalidad ejercen presiones significativas al momento de pensar a niñas y niños como sujetos con derecho a acceder a los libros, la lectura y la literatura. Asimismo, en el transcurso del proceso de investigación, la edad y la generación cobraron relevancia en tanto variables que permitían explicar procesos de exclusión y vulneración.

A continuación y, a modo de conclusión, se expone un último apartado que profundiza lo referido anteriormente, a partir de un análisis de infancia que pone el acento en el imperativo por interrogar los saberes profesionales asidos más a la lógica del sentido común que al pensamiento crítico.

\section{La estatura en la infancia: el reconocimiento de niñas y niños como sujetos autorizados.}

De una persona que vemos en la oscuridad es posible calcular a qué distancia se encuentra de nosotros, pero no su identidad (Baricco; 2012). El sostenimiento de la distancia colabora en la producción de una Otredad y así, bajo la égida de las etiquetas provenientes de un diagnóstico pretendidamente científico, se inmiscuye el sentido común institucional.

El sentido común al que hago referencia permea nuestras prácticas y a veces la teoría es insuficiente, no porque falle en su potencialidad para explicar una situación o fenómeno, sino porque el espacio propiamente interventivo es configurado a partir de consecuencias no susceptibles de ser identificadas y controladas de antemano.

Sin embargo, las imposiciones del contexto suelen exigir respuestas inmediatas, y así lo imprevisible es vedado por una urgencia material que pocas veces reconoce como importante la materialidad de los afectos, de las formas de cuidado, etcétera, despolitizando el sentido de 
convivencia y las funciones que los adultos debemos ejercer en pos del reconocimiento de derechos de niñas y niños.

Por el contrario, cuando las escuelas tratan a las niñas y niños pobres como salvajes y/o retrasados, se establece un reconocimiento a partir del cual el civilizado intentará librarse de la temeraria extrañeza organizando una campaña de exterminio (de Lajonquière; ibídem). De ahí que no resulte extraño que sea un imperativo para los docentes "modificar lo que los chicos traen de la casa" o de convertir el fracaso de la educación en fracaso del aprendizaje, culpabilizando a los niños y argumentando biológica y fisiológicamente las escasas "competencias" de estos: "Los chicos tienen problemas en el aprendizaje por la mala alimentación que reciben".

Históricamente, las instituciones escolares han tenido como función administrar la infancia en pos de constituirla cívicamente. En la actualidad, la apuesta a la construcción de ciudadanos en instituciones educativas se ha constituido como el paradigma que prescribe los horizontes del sistema y las intervenciones de sus agentes. Asimismo, siguiendo a Leiras (ibídem: 45), en lo que respecta al reconocimiento de los derechos de los niños, la función docente no parece suponer en ello ningún compromiso particular sino que se engloba en la obligación generacional de los adultos.

Benjamin (1989) sostenía que los niños pueden educar a los educadores atentos. Considero que esta premisa, que insta a los adultos (en su condición de educadores) a ser atentos con la niñez, promueve una noción de educación que no busca orientarse a la producción de sujetos acordes a un orden establecido. Por el contrario, subyace en esta directriz una actitud ética que busca generar inflexiones allí donde la rutina y la funcionalización producen maestros que reducen su vocabulario a la cuestión del orden, el autoritarismo y el sinsentido. Siguiendo a Tonucci (2004), es menester considerar que si bien podría decirse que la escuela de hoy no rechaza a ningún niño, tampoco le ofrece lo que necesita.

Por ello, contra la prescripción vacía del derecho del niño a ser escuchado, vale preguntarnos sobre las acciones que se concretizan cotidianamente para que estos realicen enunciaciones en torno a las instituciones que transitan a diario. Apostar a este tipo de registro $^{56}$, contribuye a la legitimación de un posicionamiento por parte de los adultos que, en su condición de educadores, favorece la problematización de las interacciones cotidianas.

\footnotetext{
${ }^{56}$ El registro, como instrumento para reconstruir la práctica suele ser desterrado de la labor docente por cuestiones de tiempo, por escasez de tiempo. Agamben (2001) refirió que la revolución no consiste en cambiar el mundo, sino en cambiar el tiempo. El tiempo disponible, el tiempo necesario: el tiempo, aspecto escasamente problematizado cuando se piensan modificaciones curriculares; es decir: cuáles son las formas de empleo del tiempo, qué "unidades de
} 
Para Larrosa y Pérez de Lara (1997), la infancia es lo que conocemos de ella y, también, la infancia es lo otro: lo que siempre, más allá de cualquier intento de captura, inquieta la seguridad de nuestros saberes, cuestiona el poder de nuestras prácticas y abre un vacío en el que se abisma el edificio bien construido de nuestras instituciones de acogida. Quizás por ello, en numerosas ocasiones, los adultos actuamos en pos de defender lo instituido, como explicitación de nuestro instinto de conservación culturalmente situado, recusando los discursos de niñas y niños como inverosímiles.

Recordar que los niños son del tamaño de lo que ven y no del tamaño de su altura ${ }^{57}$ es quizás una fórmula verbal para problematizar las formas de colonización que los adultos ejercemos sobre los niños, pero partiendo de una (re)vuelta sobre las herramientas que configuran nuestra "capacidad profesional de escucha". Aspectos que necesitan problematizarse si lo que pretendemos ofrecer a la niñez a través de la educación es una forma particular de conocer el mundo, a partir de una búsqueda siempre relativa de verdades provisorias.

medición" se emplean para su objetivación, cómo se jerarquizan los diferentes tiempos constitutivos de la heterogénea cotidianidad educativa, qué tiempos son excluidos.

57 "porque yo soy del tamaño de lo que veo y no del tamaño de mi altura". Pessoa, Fernando (2001). Libro del desaosiego, Buenos Aires, Emecé. 


\section{Bibliografía.}

Agamben, Giorgio (2007). Infancia e historia: destrucción de la experiencia y origen de la historia Adriana Hidalgo editora.

Antelo, Estanislao (2005). La falsa antinomia entre enseñanza y asistencia. Revista El monitor, $\mathrm{n}^{\circ}$ 4. Ministerio de Educación, Ciencia y Tecnología

Bahloul, Joelle (2002). Lecturas precarias: estudio sociológico sobre los "poco lectores". Fondo de Cultura Económica.

Baricco, Alessandro (2012). Mr. Gwyn. Barcelona, Anagrama.

Beloff, Mary (2002). Los equipos multidisciplinarios en las normas internacionales de las que surge el modelo de la Protección Integral de Derechos del Niño, Revista Justicia y Derechos del Niño, $n^{\circ}$. 4, UNICEF.

Benjamin, Walter (1982). Infancia en Berlín, Argentina, Alfaguara.

Benjamin, Walter (1989). Escritos: la literatura infantil, los niños y los jóvenes. Colección Diagonal, Ediciones Nueva Visión.

Bleichmar, Silvia (2006). Violencia social-violencia escolar: de la puesta de límites a la construcción de legalidades. Editorial Noveduc.

Bombini, Gustavo (2007). La lectura de textos literarios: episodios de una polémica didáctica. Revista Anales de la Educación, Nº (3), pp. 73-78.

Bourdieu, Pierre y Passeron, Jean-Claude (2003) Los Herederos. Siglo XXI Editores.

Bustelo, Eduardo (2007). El recreo de la infancia: argumentos para otro comienzo. Siglo XXI Editores.

Cañón, Mila (2000). Disputa o convivencia: literatura y educación. Sapiens, volumen 3, año 001. Caracas.

Cañón, Mila y Stapich, Elena (2012). Discursos asimétricos: la literatura para niños. Revista digital Estudios de Teoría Literaria, $\mathrm{n}^{\circ} 3$ (1).

Carli, Sandra (2010). Notas para pensar la infancia en la Argentina (1983-2001): figuras de la historia reciente. En Revista Belo Horizonte, v.26, nº 01, p.351-382, abril.

Carli, Sandra (coomp) (2006). En: "La cuestión de la infancia: entre la escuela, la calle y el shopping". Paidós.

Casas, Ferrán (2006). La infancia y representaciones sociales. Revista Política y Sociedad, n 43 , v. 1, p. 27-42. 
Ceirano, Virginia (2000). Las representaciones sociales de la pobreza : Una metodología para su estudio. Revista electrónica de Epistemología y Ciencias Sociales Cinta de Moebius, n 9, p. 117.

Cerletti, Laura Beatriz (2011). En torno a la escolarización infantil: un enfoque etnográfico sobre prácticas cotidianas y sentidos en disputa. Revista Inter-legere, sin más datos.

Chambers, Aidan (2007). Dime. Fondo de Cultura Económica. México.

Chartier, Anne-Marie (2004). Enseñar a leer y escribir: una aproximación histórica. México. Fondo de cultura económica.

Chartier, Roger (1992). El mundo como representación: estudios sobre historia cultural. Gedisa. Barcelona.

Chartier, Roger (1997). Obedecer y razonar. En: Pluma de ganso, libro de letras, ojo viajero. Universidad Iberoamericana.

Chaves, Mariana (2010). Jóvenes, territorios y complicidades: una antropología de la juventud urbana. Espacio Editorial.

Colángelo, María Adelaida (2003). La mirada antropológica sobre la infancia. Reflexiones y perspectivas de trabajo. Ponencia presentada en el Seminario Internacional La formación docente en el siglo XXI.

Colomer, Teresa (2005). Andar entre libros: la lectura literaria en la escuela. Fondo de Cultura Económica.

Comino, Sandra (2009). Esto no es para vos: reflexiones sobre el campo de la Literatura Infantil y Juvenil. Editorial La Bohemia.

Corea, Cristina (1995). Pedagogía del aburrido: escuelas destituidas, familias perplejas. Paidós Educador.

Danani, Claudia (2006). Politización: ¿autonomía para el Trabajo Social? Un intento de reconstruir el panorama latinoamericano. En Revista Katálysis, n²(9), Julio-Diciembre, pp. 189-199.

Daroqui, Alcira y Guemureman, Silvia (1999). "Los menores de hoy, de ayer y de siempre. Un recorrido histórico desde una perspectiva crítica”. Revista Delito y Sociedad, No 13, pp. 35-69. de Lajonquière, Leandro (2013). Los niños salvajes. En Página 12, abril.

Dubet, François y Danilo Martuccelli (1998), En la escuela. Sociología de la experiencia escolar. Losada.

Duschatzky, Silvia y Birgin, Alejandra (comps) (2001). ¿Dónde está la escuela? Ensayos sobre la gestión institucional en tiempos de turbulencia. Editorial Manantiales. 
Feixa, Carles (1996). Antropología de las edades. Ensayos de Antropología Cultural. Editorial Ariel.

Fernández, Esteban Julián y Marconi, Adriana Elena (2010). "Implicancias de la literatura infantil en la legitimación discursiva: la construcción de niños y niñas como sujetos autorizados". En Blake, Cristina y Sardi, Valeria (comps.). Literatura argentina e infancia: Un caleidoscopio de poéticas". Vuelta a casa.

Fernández, Mirta Gloria (2006). ¿Dónde está el niño que yo fui?: adolescencia, literatura e inclusión social. Editorial Biblos. Buenos Aires.

Gagliano, Rafael (2007). Los lenguajes del cuidado y los cuidados del lenguaje. Revista Anales de la Educación, $N^{\circ} 6$ (3), pp. 91-94.

Gagliano; Rafael (2006). "Cabalgatas filosóficas por la llanura pedagógica”. En Anales de la educación común.Publicación de la DGCyE de. Año 2, número 3. Abril 2006. Provincia de Buenos Aires.

Gaitán Muñoz, Lourdes (2006). La nueva sociología de la infancia. Aportaciones de una mirada distinta. Revista Política y Sociedad, v. 1, n 43, p 9-26.

García Canal, María Inés (2003). De los límites del lenguaje o el lenguaje de los límites. En Revista Tramas 21, Julio/Diciembre, pp 303-313.

García Canal, María Inés (2005). Poder, violencia y palabra. En Revista Tramas 25, Julio/Diciembre, pp. 113-128.

García Canal, María Inés (2006). El espacio del lenguaje y del pensamiento. En Espacio y poder: el espacio en la reflexión de Michel Foucault. México DF: UAM-X, CSH, Departamento de Política y Cultura.

Geertz, Clifford (1996). Tras los hechos. Dos países, cuatro décadas, un antropólogo. Paidós. Barcelona.

Gentili, Pablo (2011). Pedagogía de la igualdad ensayos sobre la educación excluyente. Siglo XXI Editores.

Gerbaudo, Analía (2010). Reinscripciones del cuerpo y de la historia: la literatura y otras formas del arte en la escuela secundaria argentina. Revista Lulú Coquette, n 5, Agosto, pp. 11 29.

Giardinelli, Mempo (2006). Volver a leer: propuestas para ser una nación de lectores. Editorial Edhasa. Buenos Aires.

Ginzburg, Carlo (1994). "Indicios. Raíces de un paradigma de inferencias indiciales". En: Mitos, emblemas, indicios. Editorial Gedisa.

Guber, Roxana (1991). El salvaje metropolitano. Editorial Legasa. 
Gutiérrez Valencia, Ariel (2009). "El estudio de las prácticas y las representaciones sociales de la lectura: génesis y el estado del arte”. Anales de documentación, número.12, pp. 53-67.

Hesse, Herman (2005). El lobo estepario. Arenal.

István Mészáros (2008). La educación más allá del capital. Primera Edición. Buenos Aires. Siglo XXI Editoresa.

Iturrioz, Paola (2010). La escritura como práctica socio-cultural: otras categorías para otros problemas. Revista Lulú Coquette, pp. 36-53.

Kaplan, Viviana Carina (2008). Talentos, dones e inteligencias: el fracaso escolar no es un destino. Editorial Colihue. Buenos Aires.

Klein, Irene (2007). La ficción de la memoria: la narración de historias de vida. Argentina. Editorial Prometeo.

Langeveld, Martinus (2005). "La necesidad de una antropología del niño". Revista Educación y Pedagogía, v. 17, n 42, p. 69-74.

Larrosa, Jorge (2000). "El enigma de la infancia". En Pedagogías profanas. Novedades educativas.

Lechermeier, Philippe (2008). Princesas olvidadas o desconocidas, editorial EDELVIVES.

Leiza de Almada, María Elena y Duarte, María Dolores. Lo que nunca me atreví a confesar. La lectura en la memoria docente. Revista Diálogos Pedagógicos, nº 13 (VII), año 2005, pp. 4762.

Lerner, Delia (1993). Capacitación en servicio y cambio en la propuesta didáctica vigente. Ponencia presentada en el Encuentro de especialistas auspiciado por el CERLALC. Bogotá, 6 al 8 de Octubre.

Lewkowicz, Ignacio (2004). Frágil el niño, frágil el adulto. Página 12, 4 de Noviembre de 2004. Disponible en http://www.pagina12.com.ar/diario/psicologia/9-43161-2004-11-04.html Llobet, Valeria (2004). ¿Fábricas de niños? Las instituciones en la era de los derechos. Editorial

Lluch, Gemma. Cómo analizamos relatos infantiles y juveniles. Colección Catalejo. Grupo Editorial Norma. Colombia.

Lorente Molina, Belén (2004). Género, ciencia y trabajo. Las profesiones feminizadas y las prácticas de cuidado y ayuda social. Revista Scripta Ethnologica, año/vol. XXVI, Consejo Nacional de Investigaciones Científicas y Técnicas, Buenos Aires, Argentina, pp. 39-53.

Marcuse, Herbert (1970). Cultura y sociedad: acerca del carácter afirmativo de la cultura. Editorial Sur.

Marradi, Alberto y otros (2007). Metodología de las Ciencias Sociales. Emecé. 
Milstein, Diana (2008). Conversaciones y percepciones de niños y niñas en las narrativas antropológicas. Revista Sociedade e Cultura, n 1 (11), pp. 33-40.

Milstein, Diana y otros (2007). "Panorama de la Antropología y la Educación escolar en la Argentina 1982-2006". Anuario de Estudios en Antropología Social 2006, Centro de Antropología Social - IDES, p. 77-96.

Moreno Arteaga, José (2005). De la didáctica de la Literatura a la transmisión de literatura: reflexiones para una nueva educación literaria. Revista de Estudios Literarios, Universidad Complutense de Madrid.

Mscitti, Guillermo (2009). En: "Prácticas de lectura de literatura para resignificar las experiencias de observación y acción pedagógica de alumnos del profesorado”. En:”Nuevas infancias y juventudes". Colección Educación.

Nakamura Aburto, Laura y Peralta López, Víctor Manuel (2004). El libro-álbum y las intervenciones docentes. Revista Novedades Educativas, n 165 , pp. 18-23.

Oyhandy Cioffi, Ángela (2004). La infancia en riesgo: entre la caridad y la ciudadanía: un estudio sobre la gestión de la infancia en riesgo en la Argentina contemporánea. Tesis para optar el grado de Maestro en Ciencias Sociales. FLACSO.

Patte, Geneviéve (1998). Déjenlos leer: los niños y las bibliotecas. Fondo de Cultura Económica.

Pavez Soto, Iskra (2012). "Sociología de la Infancia: las niñas y los niños como actores sociales”. Revista Sociología, n 27, p. 81-102.

Peña, Luis Bernardo y Pedro León Cortés (2004). "Las políticas públicas de lectura: una visión desde sus actores". En: Agenda de políticas públicas de lectura. CERLALC-OEI, Plan Iberoamericano de Lectura-ILÍMITA-.

Peroni, Michel (2003). Historias de lectura: trayectorias de vida y de Lectura. Fondo de Cultura Económica.

Pescetti, Luis María (2004). Nadie te creería. Argentina, Alfaguara Infantil.

Pessoa, Fernando (2001). Libro del desaosiego. Emecé.

Petit, Michel (1999). Nuevos acercamientos a los jóvenes y la lectura. Fondo de Cultura Económica.

Petit, Michel (2001). En: “Lecturas: del espacio íntimo al espacio público”. Fondo de Cultura Económica.

Pizarnik, Alejandra (2000). Poesía completa. Barcelona: Lumen.

Puntano, Erica Daniela (2011). Reforma educativa, diseño curricular y docencia: un campo tensionado. Revista El toldo de Astier, $\mathrm{n}^{\circ} 2$. 
Rancière, Jacques (2010). El espectador emancipado. Editorial Manantial.

Raymond, Williams (2000). En: "Marxismo y literatura". Ediciones Península.

Reguillo, Rossana (2004). La performatividad de las culturas juveniles. Revista Estudios de juventud, $\mathrm{n}^{\circ}$ 64, pp. 49-56, 2004.

Rockwell, Elsie (1986). La relevancia de la etnografía para la transformación de la escuela. Memorias del Tercer Seminario Nacional de Investigaciones en Educación, Bogotá, Centro de Investigación de la Universidad Pedagógica e Instituto Colombiano para el Fomento de la Educación Superior, Serie Memorias de Encuentros Científicos Colombianos, Organizado por la Universidad Pedagógica Nacional, p. 15-29.

Rockwell, Elsie (2001). La lectura como práctica cultural: conceptos para el estudio de los libros escolares. Revista Educação e Pesquisa, n 1, v. 27, pp. 11-26.

Roffo, Analía. En los sectores populares no se lee poco ni sin interés. Entrevista a Bernard Lahire. Diario Clarín, 30-07-2006.

Ruiz Silva, Alexander (2008). Entre el hechizo de Circe y la voluntad de Odiseo: sobre los problemas de la formación ciudadana. En: Ética discursiva y educación. Cooperativa Editorial Magisterio, Bogotá Saintout, Florencia (2007). Cultura y ciudadanía: la lectura como un derecho. En: Anales de la educación común. Año 3, número 6. Publicación de la Dirección General de Cultura y Educación de la Provincia de Buenos Aires.

Salas Cerón, Liliana Patricia (2010). Calidad de vida y la nueva sociología de la infancia. Revista Perspectivas de Investigación Social Complementarias Hologramáticas, v. 04, n 7, p. 83-95.

Santillán, Laura (1999). Las iniciativas educativas familiares bajo análisis: notas sobre la dimensión social y política del cuidado. Editorial Santillana.

Sardi, Valeria (2007): Historias de lectura y escritura en la escuela: entre la ruptura y la hegemonía. En Revista Anales de la educación común, Tercer siglo, año 3, número 6. Publicación de la Dirección General de Cultura y Educación de la Provincia de Buenos Aires. Sawaya, Sandra (2008). Alfabetización y fracaso escolar: problematizando algunas presuposiciones de la concepción constructivista. Revista Lulú Coquette, $\mathrm{n}^{\circ}$ 4, año 3.

Sierra i Fabra, Jordi (2002). Querido bijo: estás despedido. Madrid, Editorial Alfaguara.

Soriano, Marc (1995). La literatura para niños y jóvenes: Guía de exploración de sus grandes temas. Ediciones Colihue. Año 1995.

Spivak, Gayatri Chakravorty (2008). ¿Puede hablar el sujeto subalterno? En Revista Orbis Tertius, $\mathrm{n}^{\circ} 3(6)$. 
Tedesco, Juan Carlos (2008). “¿Son posibles las políticas de subjetividad?”. En Emilio Tenti Fanfani (comp.), Nuevos temas en la agenda de política educativa. Instituto Internacional de Planeamiento de la Educación, Unesco/Siglo X XI.

Teulé, Jean (2008). La tienda de los suicidas, Barcelona, Braguera.

Wernicke, María (2012). Hay días, Buenos Aires, Calibroscopio.

Yourcenar, Marguerite (1991). Alexis o el tratado del inútil combate. Alfaguara.

\section{Sitios web consultados}

Shock, Susy (2010). Disponible en web http://www.youtube.com/watch?v=udup-LFqnXI Entrevista a Francesco Tonucci (2004). Disponible en ebs.uvigo.es/consumoetico/textos/textos/entrevista a f tonucci.doc Cassirer, Ernst (1979). La tragedia en la cultura. Disponible en: http://www.philosophia.cl/biblioteca/cassirer/La $\% 20$ tragedia $\% 20$ en $\% 201 \mathrm{a} \% 20$ cultura.pdf 